\title{
Lighting the Eighth Fire
}

Acknowledgement, Accountability and Engagement on Asinabka

by Sophie Lamothe

Thesis submitted to:

The Faculty of Graduate and Postdoctoral Affairs

In partial fulfilment of the requirements for the degree of: Master in Architecture

Azrieli School of Architecture and Urbanism

Carleton University, Otawa, Ontario, Canada

(C) Sophie Lamothe 2012-2013 
Library and Archives

Canada

Published Heritage

Branch

395 Wellington Street

Ottawa ON K1A ON4

Canada
Bibliothèque et

Archives Canada

Direction du

Patrimoine de l'édition

395 , rue Wellington

Ottawa ON K1A ON4

Canada
Your file Votre référence

ISBN: 978-0-494-94564-3

Our file Notre référence

ISBN: $978-0-494-94564-3$
NOTICE:

The author has granted a nonexclusive license allowing Library and Archives Canada to reproduce, publish, archive, preserve, conserve, communicate to the public by telecommunication or on the Internet, loan, distrbute and sell theses worldwide, for commercial or noncommercial purposes, in microform, paper, electronic and/or any other formats.

The author retains copyright ownership and moral rights in this thesis. Neither the thesis nor substantial extracts from it may be printed or otherwise reproduced without the author's permission.
AVIS:

L'auteur a accordé une licence non exclusive permettant à la Bibliothèque et Archives Canada de reproduire, publier, archiver, sauvegarder, conserver, transmettre au public par télécommunication ou par l'Internet, prêter, distribuer et vendre des thèses partout dans le monde, à des fins commerciales ou autres, sur support microforme, papier, électronique et/ou autres formats.

L'auteur conserve la propriété du droit d'auteur et des droits moraux qui protege cette thèse. $\mathrm{Ni}$ la thèse ni des extraits substantiels de celle-ci ne doivent être imprimés ou autrement reproduits sans son autorisation.
In compliance with the Canadian Privacy Act some supporting forms may have been removed from this thesis.

While these forms may be included in the document page count, their removal does not represent any loss of content from the thesis.
Conformément à la loi canadienne sur la protection de la vie privée, quelques formulaires secondaires ont été enlevés de cette thèse.

Bien que ces formulaires aient inclus dans la pagination, il n'y aura aucun contenu manquant. 
First, I wish to thank Lucie Fontein who allowed me to open my architectural horizons while supporting my initial vision. I gained knowledge and a way of addressing architecture more modestly that will always influence me.

I also especially thank Roger Connah for his dedication and commitment as a professor and director but mainly as a man.

I am grateful to Claudette Commanda and Bret Cardinal for taking the time for sharing their vision and work, which have inspired and influenced me throughout this thesis and which continue do so.

Finally, I want to thank all my loved ones who have encouraged and supported me in writing and production of this thesis, for which I am extremely proud.

Merci à Jonathan pour sa patience. 


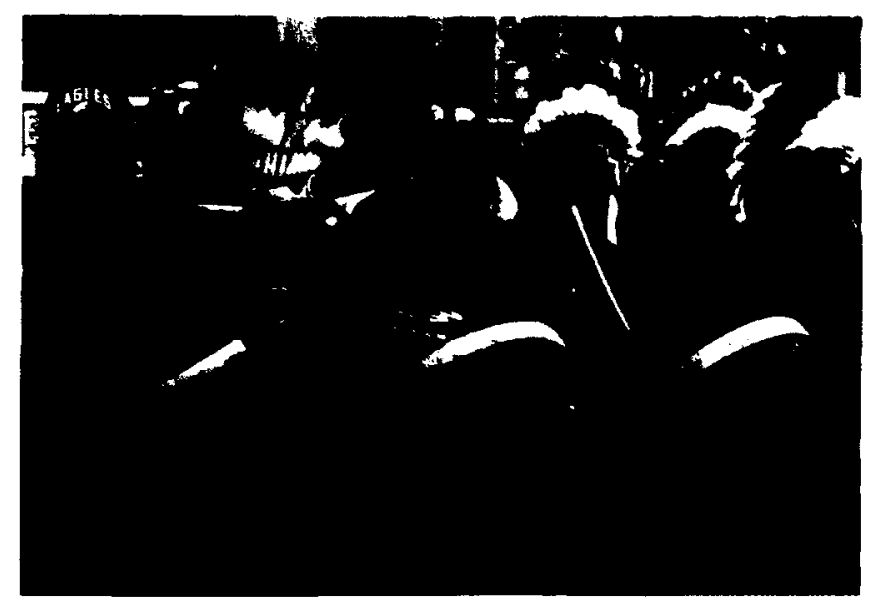

Chartrand, Fred (January 11, 2013), for The Canadian Press.

Aboriginal protest in front of Parliament Buildings against bills $C-38$ and $C-45$. 
As people of the First Nations of Canada we have a vision of the sort of country we want to live in and to build in collaboration with other Canadians. It is certainly not the sort of country we have now, one in which our people have been relegated to the lowest rung on the ladder of Canadian society. We do believe, however, that our situation can be turned around.

We believe not only that we can rescue ourselves from these depressing conditions, but that in the process we can contribute enormously to the health, effectiveness, and decency of Canada, benefitting every person who lives in this country.

Georges Erasmus

Former National Chief,Assembly of First Nations (in the introduction of Drumbeat: Anger and Renewal in Indian Country, Michigan: Motor City Books, 1989.) 


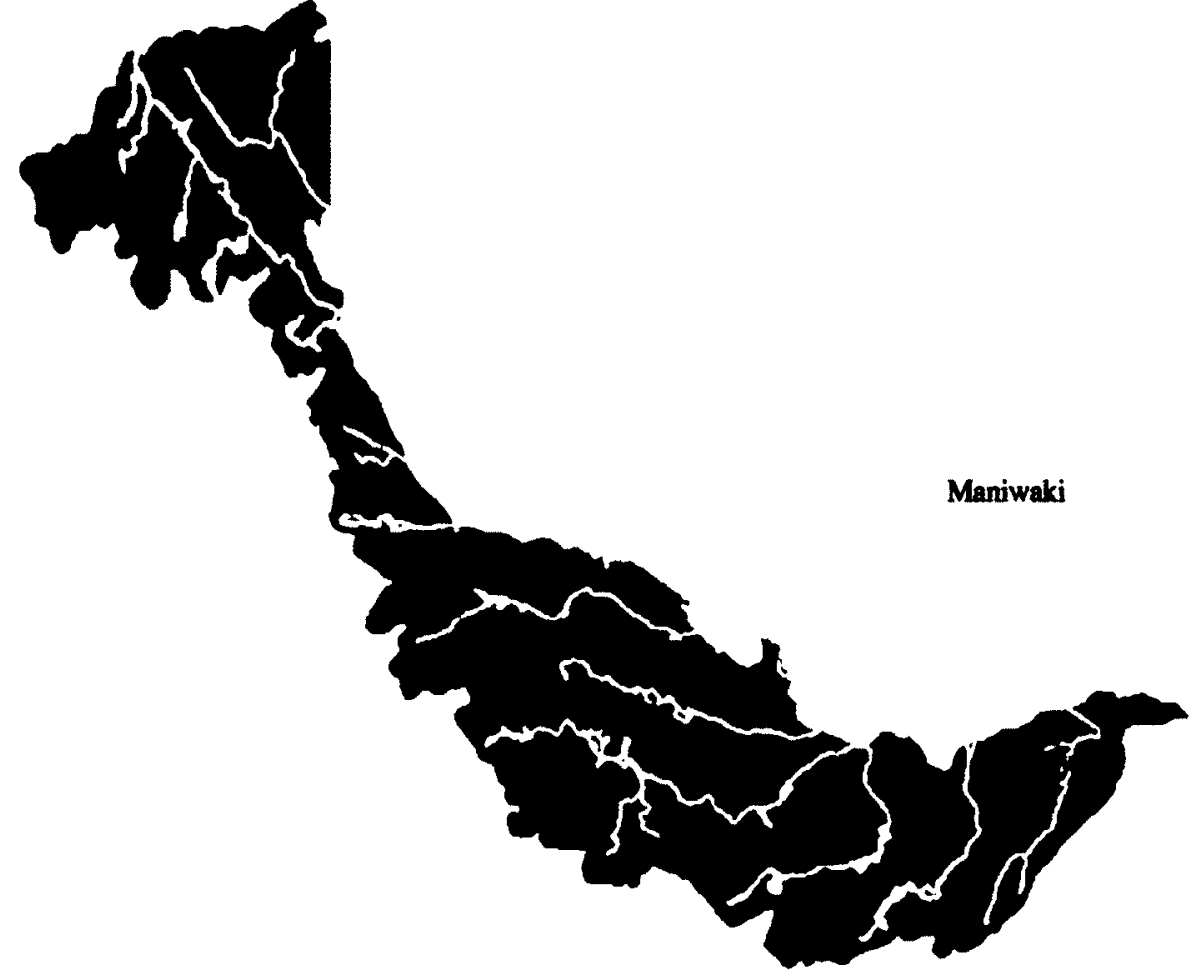

ONTARIO
The Ottawa River serves as the boundary between the provinces of Quebec and Ontario, even if the river is the central component of the Algonquin homeland.

from Otlawa Water Institute (2012). The Ottawa River Watershed. 


\section{Abstract}

Asinabka, the Algonquin term for Victoria and Chaudière Islands (situated in the Ottawa River just west of the Canadian Parliament Buildings) has been disputed territory since the arrival of

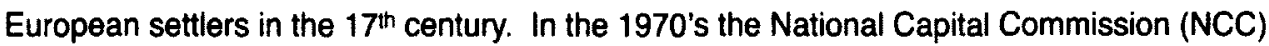
acknowledged Victoria Island as Algonquin land and designated it as the site for a National Indigenous Centre, including it among other Canadian landmarks on Confederation Boulevard. In the 1990's the NCC commissioned Architect Douglas Cardinal to begin developing a scheme for the centre. His latest design proposes a monumental building that incorporates the existing Union Carbide Mill ruins completely within it.

In Lighting the Eighth Fire, I present a counterproposal for the National Indigenous Centre that acknowledges, is accountable to, and engages the Algonquins on Asinabka as fundamental members of our Canadian fabric. The design strategy is based on principles of restorative justice as defined by the Algonquin Nation, and weak thought as interpreted by Gianni Vattimo, with the intention of formulating a moment of reconciliation and reinvigoration. 


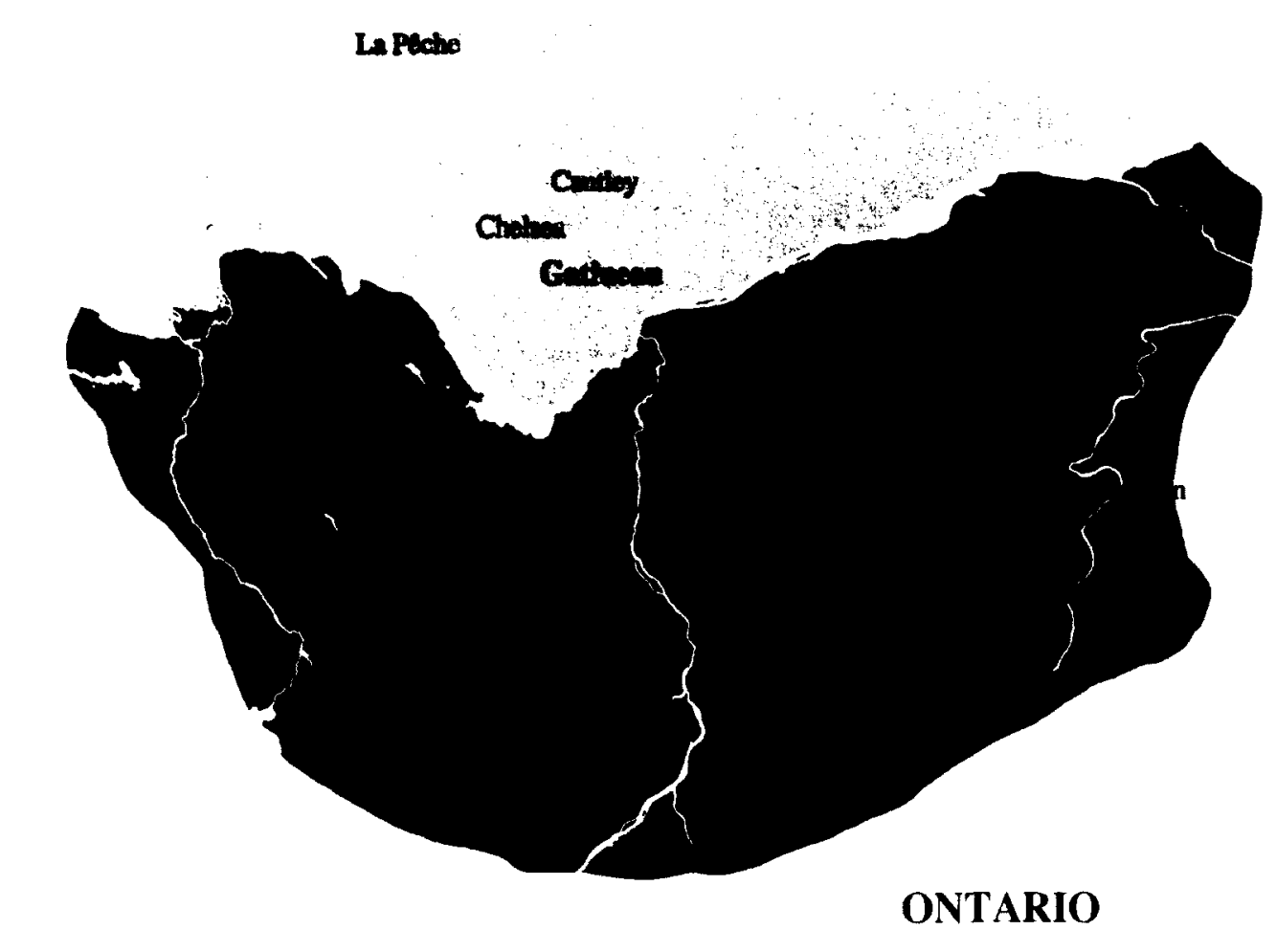




\section{Contents}

Preface

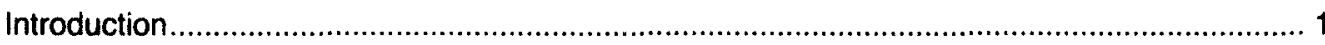

Part 1: Omàmiwinni: The Victim - Acknowledgement and Restoration ................................. 13

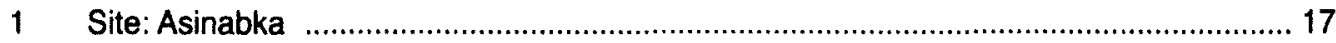

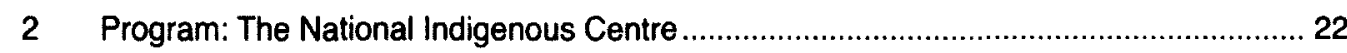

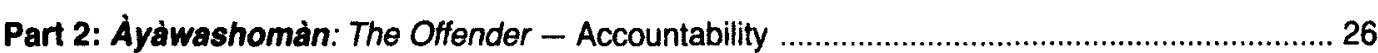

3 Acceptance: Awareness of Colonialism ...................................................................... 31

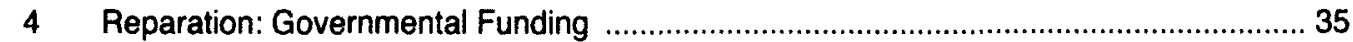

Part 3: Nihinawizl: The Community - Engagement …............................................................ 41

5 The Circle: Representation of the Community ............................................................ 45

6 Achievement: Community Participation .................................................................. 49

Part 4: The Asinabka National indigenous Centre - Porttolio ....................................................5

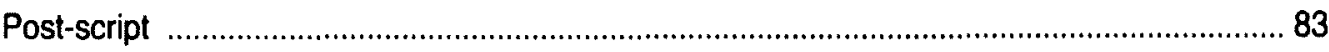

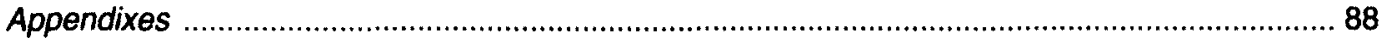

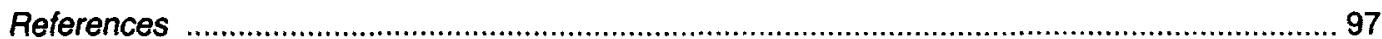




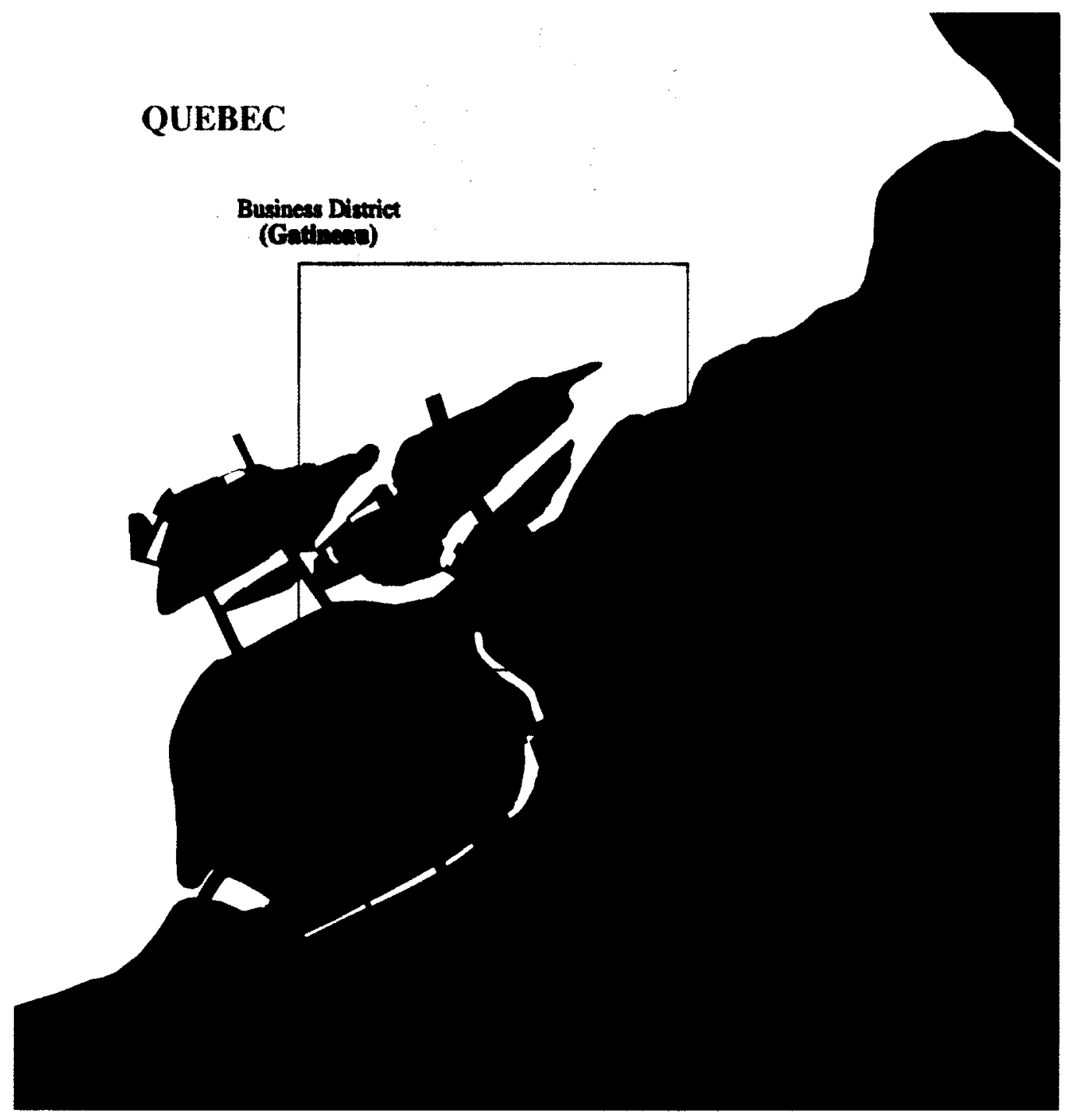

Victoria Island lies at the boundary between the provinces of Ontario and Québec in the Ottawa River.

from GIS Carleton University (2012). Centre of the National Capital Region. 


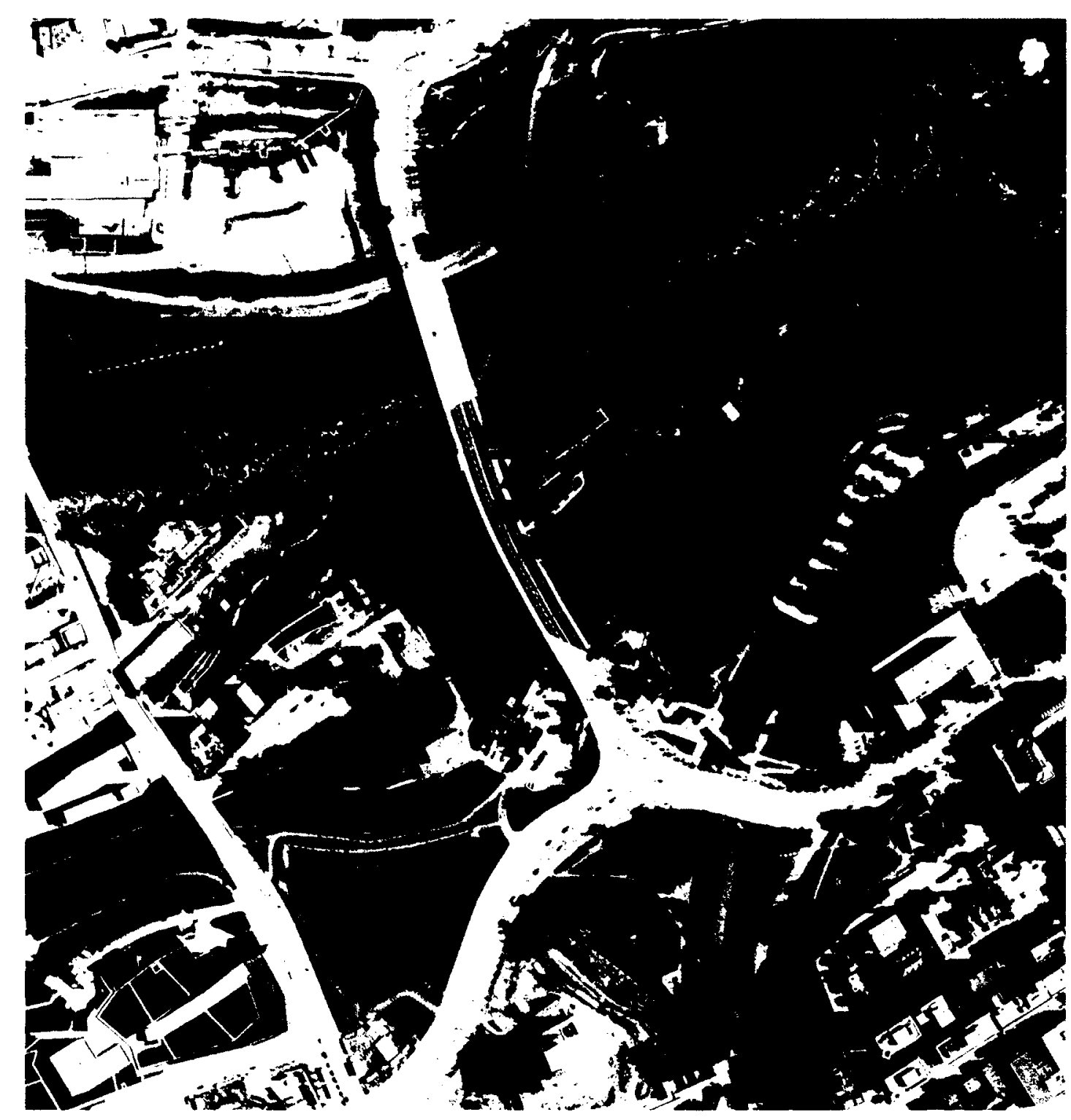

Panoramic Views:

Northwest from Richmond Landing Northeast from Portage Bridge: Southeast from rear of ruins:

SouthWest from rear of ruins

East from Portage Bridge towa;rds Parliament Hill;

East from Portage Bridge:

Northwest from Portage Bridge:

Southwest towards Portage Bridge.

from GIS Carleton University (2012). Victoria Island 

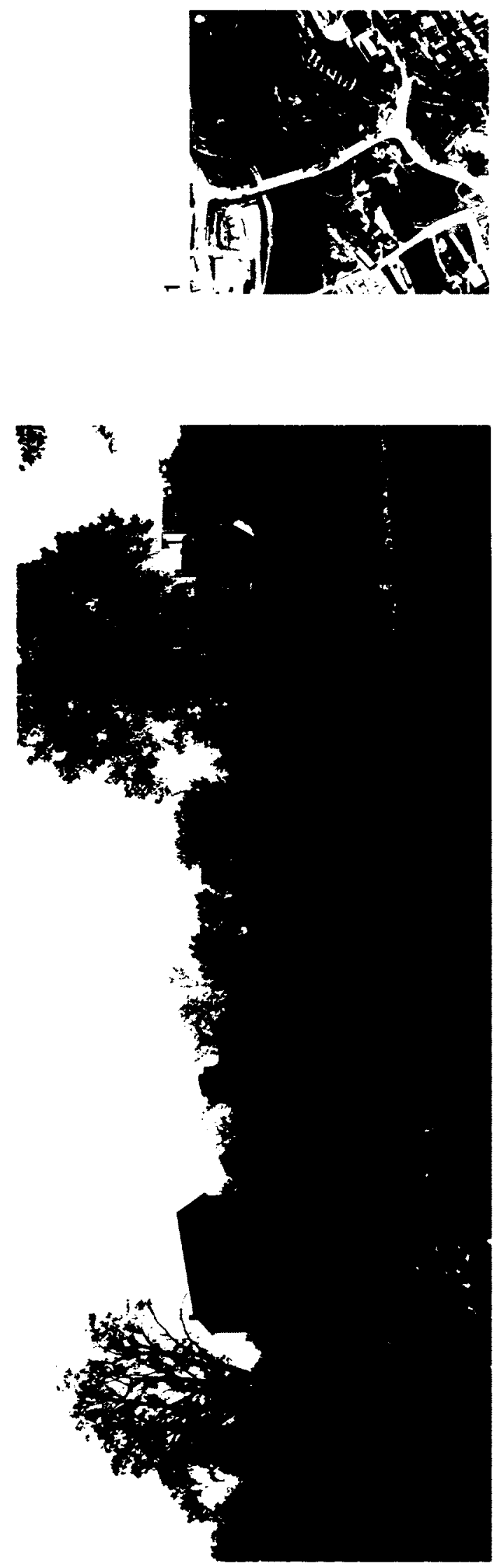

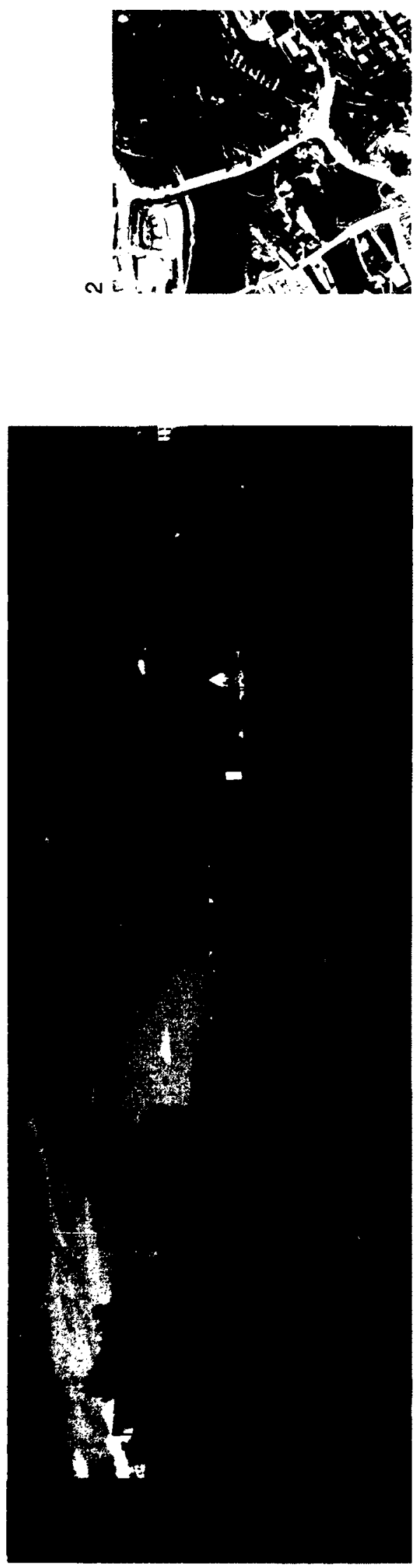

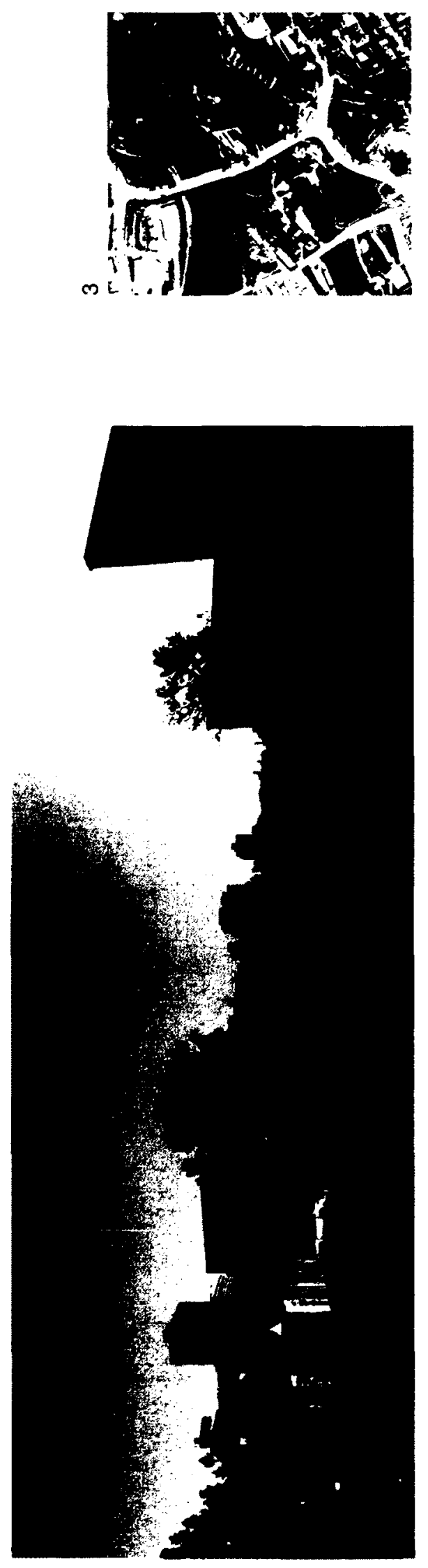

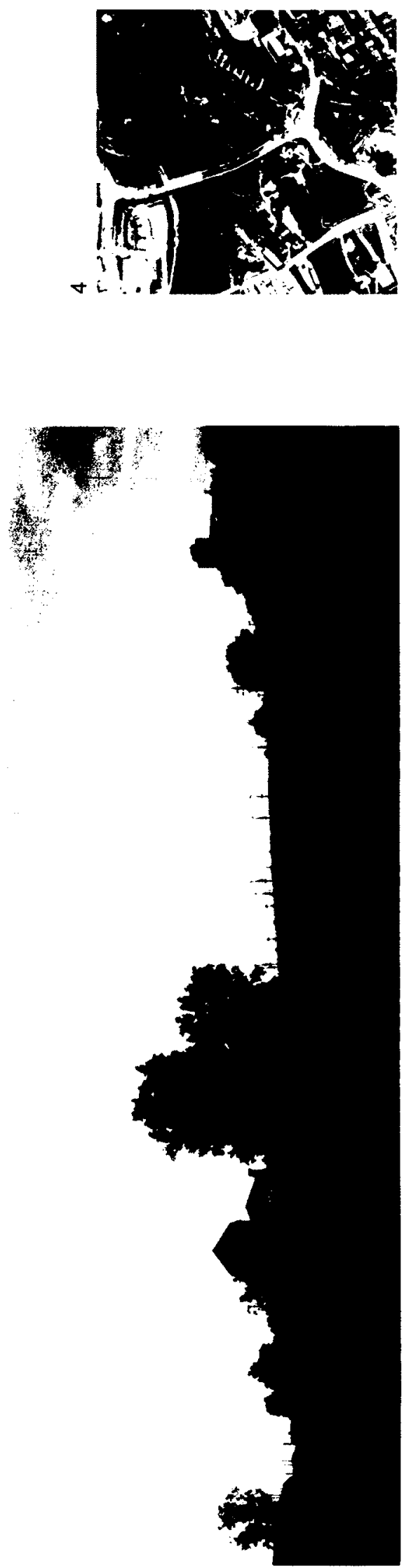

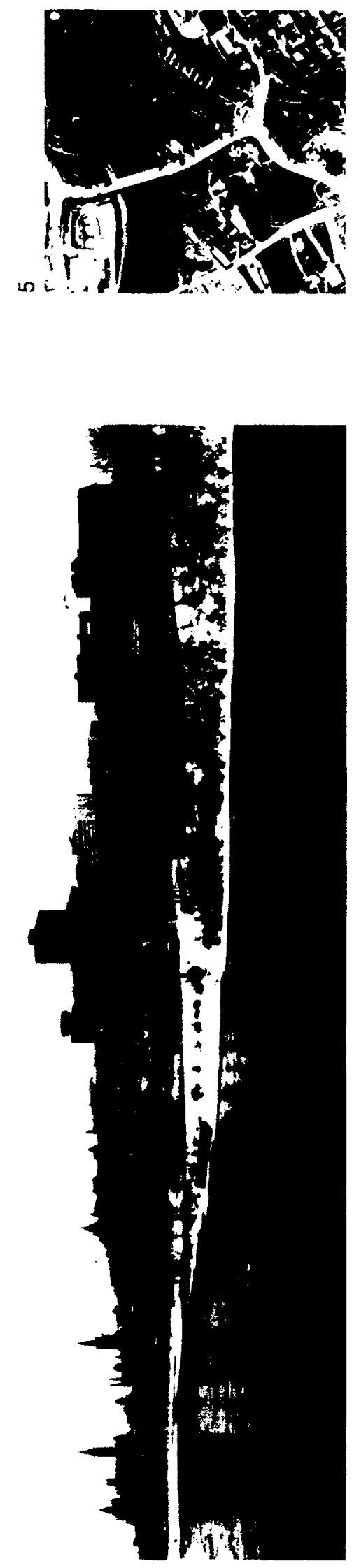

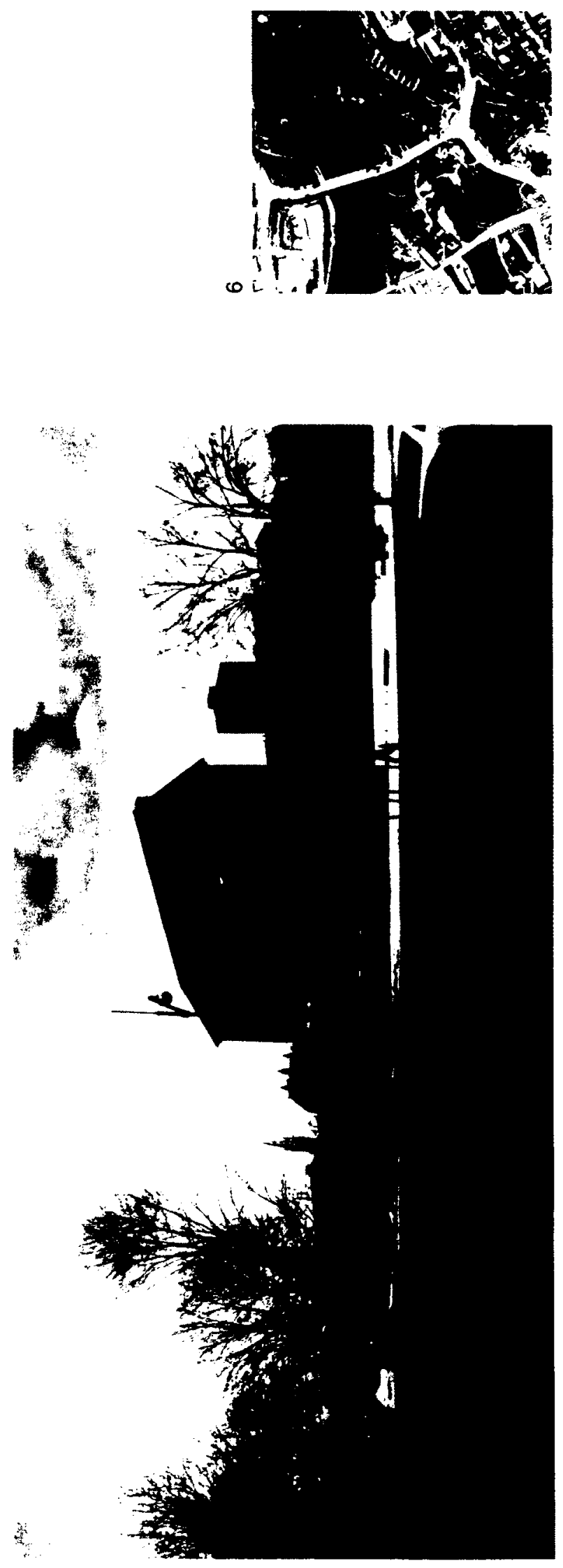

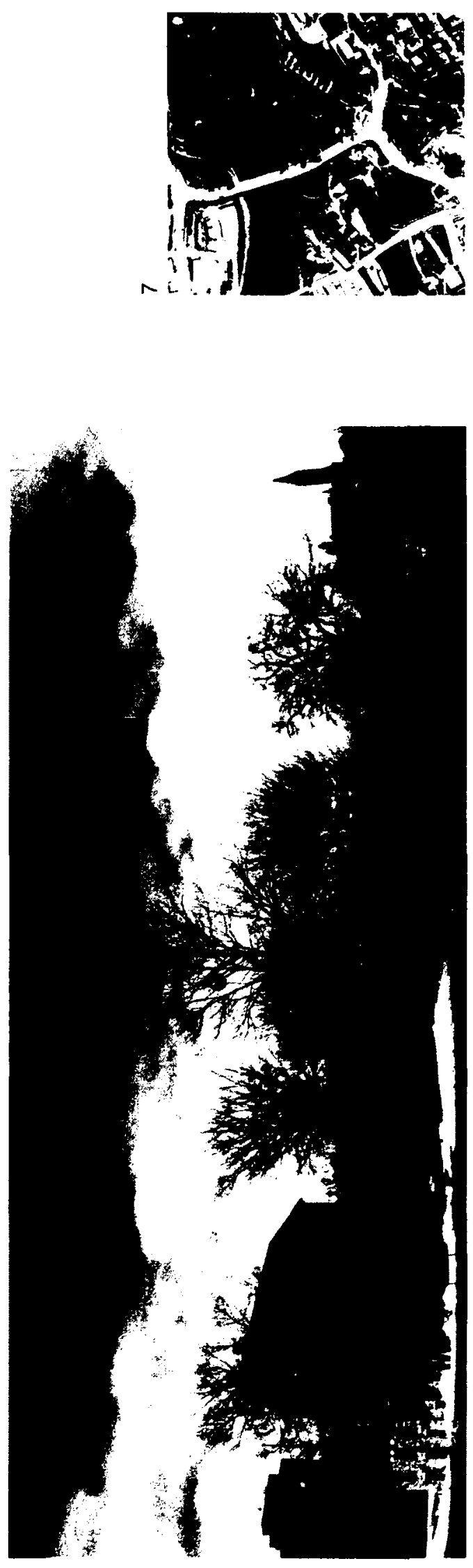

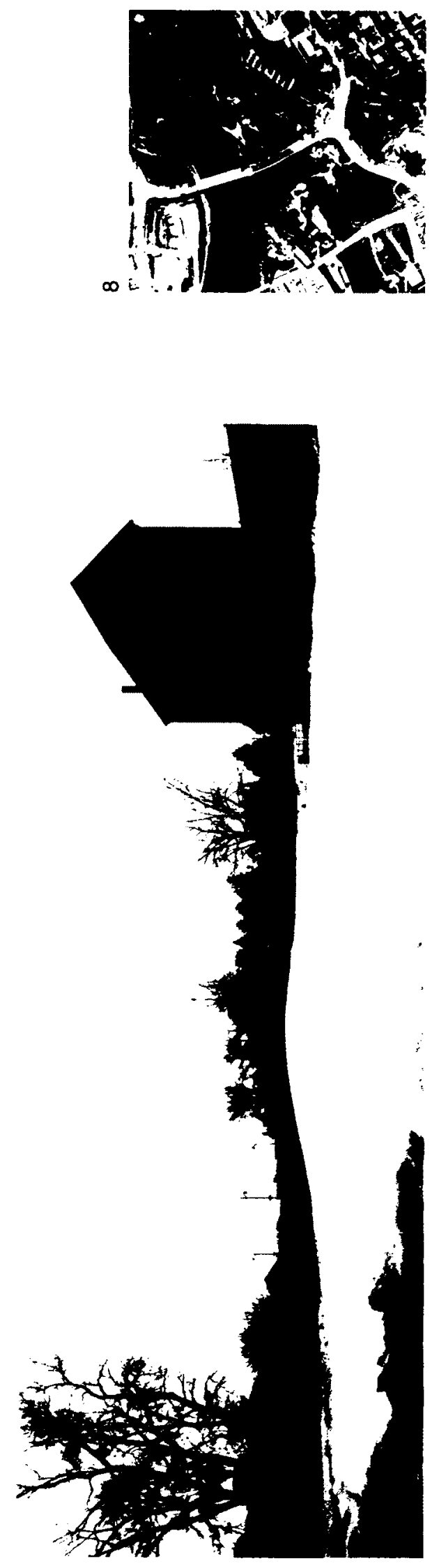


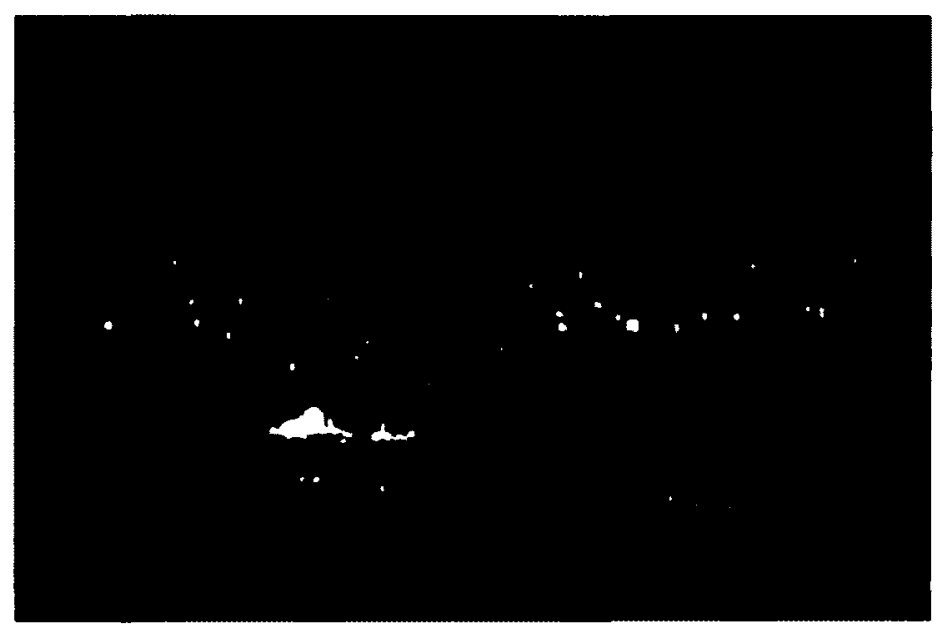

Great Places in Canada (2012) [http://www.cip-icu.ca/greatplaces/en]. Algonquin Sacred Fire Ceremony. 
Oshkimaadiziig are responsible for decolonizing, for rebuilding our nation, and for forging new relationships with other nations by returning to original [Algonquin] visions of peace and justice.

According to the prophecy, the work of the Oshkimaadiziig determines the outcome of the Eighth Fire, an eternal fire to be lit by all humans. It is an everlasting fire of peace but its existence depends upon our actions and our choices today.

The Seventh Fires Prophecy

Explained by Leanne Simpson (in her book Lighting the Eighth Fire: The Liberation. Resurgence and Protection of Indigenous Nations, Winnipeg Arbeiter Ring Publishing, 2008.) 
The Seven Fires prophecy of the Algonquins speaks directly to the lighting of the eighth fire, a concept that represents the current and global situation of Indigenous people. ${ }^{1}$ I have been inspired by this vision since it seeks the wellness of all beings and things, including Mother Earth. The Seven Fires prophecy consists of a series of sacred predictions that have foretold the Algonquin story since the beginning of Creation. ${ }^{2}$ This prophecy is represented in the Seven Fires wampum belt. ${ }^{3}$

\section{The Seven Fires Prophecy and Wampum Belt}

In 1970 Elder William Commanda became the keeper of three sacred wampum belts of historical and spiritual importance - including the Seven Fires Prophecy Belt, the 1700's Belt and the Jay Treaty Border Crossing Belt. 4 The Seven Fires Prophecy Belt contains seven diamond-shaped figures, representing the messages of seven prophets, evenly distributed across the belt, except for the central and fourth figures that consists of two overlapping diamonds. Leanne Simpson, scholar and member of the Mississaugas of Alderville First Nation, relates that we are currently in the later part of the prophecy: the Seventh Fire. ${ }^{5}$ She explains that the Seventh Fire represents a time when, after a long period of colonialism and cultural loss, new people, the Oshkimaadiziig, emerge. The Oshkimaadiziig are responsible for reviving Algonquin language, philosophies, political and economic traditions, and culture. Simpson also states that in order for the Eighth Fire to be lit, settler society must also choose to change its ways, decolonize its relationships with the land and Indigenous Nations, and join them in building a sustainable future based upon mutual recognition, justice, and respect. Leanne Simpson states:

"For Nishnaabeg people, our prophecy is the foundation of our resistance and resurgence. [...] If we are to take seriously our current responsibilities, our generation has a profound

' $0^{m}$ Fire' is also the titie of a series of documentary broadcast on CBC since January $13^{\mathrm{m}}, 2013$ Simpson, 2008: 13.

Refer Appendix 1 for complete description of the Seven Fires prophecy.

Circle of All Nations, 2008 .

Simpson, 2008: 14.
$\{$ Algonquins $\}$

This name was brought by French explorers and is still in use today to describe the Omàmiwinini ("down-river peoplen). Another common term used to describe Algonquin is Anishinabeg ("original people" or "good human"). Other First Nation people also refer to Algonquins as Nishinabeg.

- Algonquins of Pikwàkanagàn First Nation (2012)

$\{$ Wampum Belt $\}$

a belt of varicoloured wampum [beads] arranged in patterns and used as a ceremonially device in the ratification of treaties.

- Merriam-Webster Dictionary

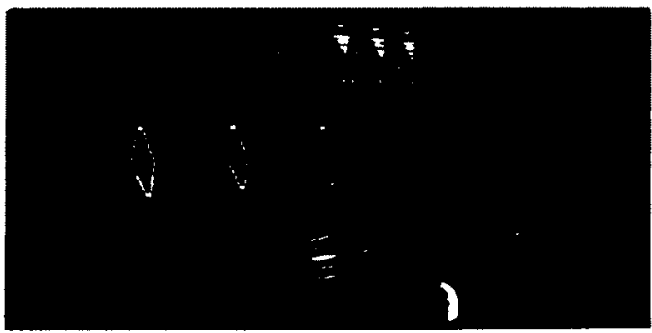

1- (top) The1700's Belt;

2- (middle) The Seven Fires Prophecy Belt;

3- (bottom) The Jay Treaty Crossing Belt.

Laramée, Diane (June 21, 2006). Commanda, keeper of three wampum belts. 
ability to contribute to the recovery and rebirth of Indigenous Nations, and to peaceful and just relations with our neighbouring nation states." 6

The Eighth Fire will bring political decolonization, cultural reclamation and resurgence,

liberation, and peaceful coexistence. These principles will be the foundations underlying the

development of this different vision for the Asinabka National Indigenous Centre.

6 Simpson, 2008: 14. 


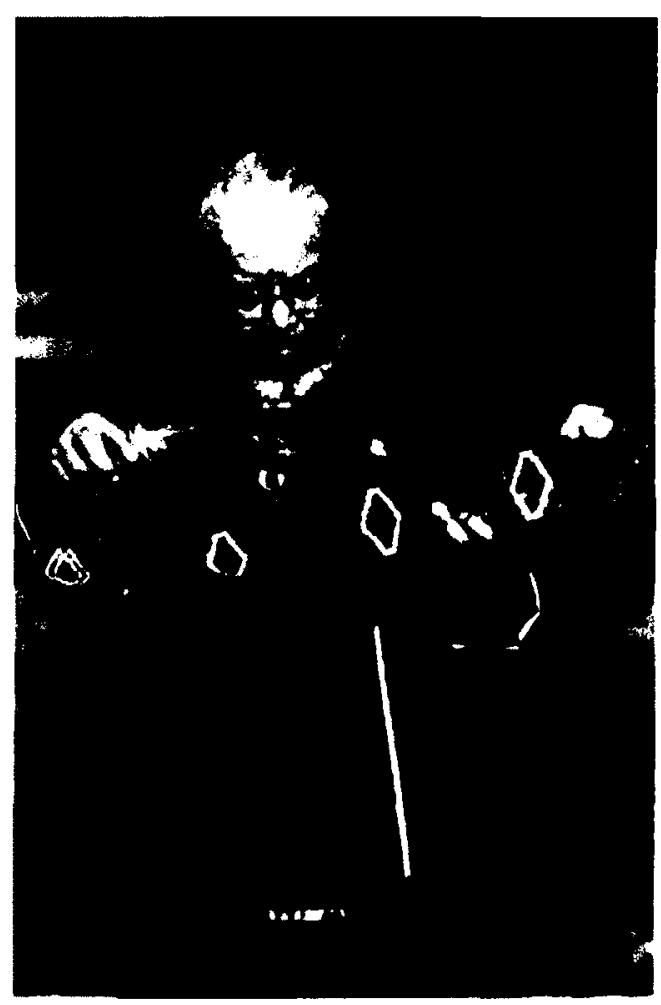

Circle of All Nations (October 01, 1995).

Grandfather Commanda shows the Seven Fires Prophecy

Wampum Beit at the prayer vigit. 


\section{Introduction}


Since the colonization of Canada during the seventeenth century, the Algonquins have claimed Asinabka, the Algonquin term for Victoria and Chaudière Islands, as part of their homeland. This homeland comprehends $148000 \mathrm{~km}^{2}$ divided between the provinces of Ontario and Québec. The Kiji Sibi watershed, better known as the Ottawa River Valley, ${ }^{1}$ has been fractured since the Constitutional Act of 1791 and the creation of the Upper and Lower Canada. ${ }^{2}$ Over the past centuries, the Algonquins have seen settlers acquire their land, and industries develop on their unceded territory. In the 1970's, former National Capital Commission (NCC) Chairman Jean Pigott formally recognized these islands as Algonquin territory and proposed Victoria Island as the site for a National Indigenous Centre, ${ }^{3}$ to be included amongst Canada's landmarks along Confederation Boulevard. ${ }^{4}$ Protests followed, since the land is considered to be a spiritual place, ${ }^{5}$ but since then the idea has evolved in the minds of the Algonquin people. Primarily through the work and effort of Elder William Commanda, the Asinabka National Indigenous Centre is currently a project supported by the Algonquins, other Canadian Aboriginals and non-Aboriginals alike.

In the 1990's the NCC commissioned Architect Douglas Cardinal to develop the first schematic design of the centre. ${ }^{6}$ Since then, Cardinal's design has passed through various propositions and currently presents a modern, monumental and massive centre. The latest version proposes to suppress the presence of existing industrial ruins, the Union Carbide Mill ruins, by hiding the latter inside the centre, and presenting them as a vestige from the past. Although the elaboration of the project is still ongoing, I present a counterproposal that addresses the existing ruins and the landscape as a whole in a different way. The intention of the design is to acknowledge the history of the site, be accountable for past wrongs and present obligations, and engage the Algonquins on Asinabka as foundational members of Canadian society.
$\{$ Kiji Sibi $\}$

Known as the Ottawa River since the 1800 s. The river rises from its source in Lake Capimitchigama and drains into the St-Laurent River; thereby dividing the provinces of Ontario and Québec.

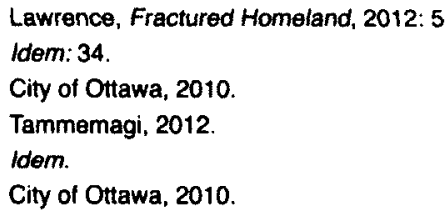




\section{Power Relationships}

Patterns of domination can be identified through different periods in history reflecting a condition where, usually for religious beliefs or political control, one group claims governing power over weaker social groups or units. These patterns can also be observed in architecture, which has a long history of cultural domination through architectural form and construction. For example, during the Middle Ages, Synagogues were repurposed as Churches to make manifest the forced conversion of the Jews to Christianity. Similarly extensive urban interventions such as the planning of New Delhi were clearly designed to communicate the power of the British Empire. Modernism, with its tabula rasa mentality, describes a power relationship over the past by promoting a complete rejection of the existing built environment in favour of new and innovative construction.

$$
\text { ...... }
$$

The idea of Architecture as communicating power relationships has been explored by a number of philosophers and thinkers. In Framing Places: Mediating power in built form, Kim Dovey brings attention to the difference between "power over" something and "power to do" something, suggesting a more positive approach to the idea of power. In order to distinguish these forms of power, one has to understand first its etymology; the term "power" derives from the Latin potere which means "to be able", the capacity to achieve some end. ${ }^{7}$ Dovey explains that in everyday life we tend to notice "power over" while "power to" is taken for granted. This creates the illusion that "power over" is somehow primary - an illusion which suggests an opposition between power and emancipation. As Dovey demonstrates, "power over" can be defined as the power of one agent, or group, over another; the power to ensure the compliance of the other with one's will. Force,

coercion, manipulation, seduction and authority are various concepts of "power over" presenting different scale of power relationships. ${ }^{8}$ This is the kind of power that First Nations people associate with the colonists. Through the building of the Asinabka National Indigenous Centre, the intention 
of this thesis is to instead engage the liberating form of power. This will enable the Algonquins to come to grips with their subjection to colonialism in a positive and forward looking manner.

This distinction between "power to" and "power over", between power as liberation and as oppression, is fundamental and will influence one's empowerment. Dovey states: "Empowerment is linked with "autonomy" and "freedom", both of which imply a "liberation" from arbitrary forms of "power over" us." ${ }^{9}$ Since the establishment of Europeans in Canada, Aboriginal people struggle for decolonization 10 - the liberation of the Aboriginals from the oppressive "white power."

Decolonization is a process for emancipation - yet emancipation is precisely a form of empowerment, of enhanced capacity, as Dovey declares. ${ }^{11}$ To allow the Algonquin emancipation, the design strategies have to explore power as a positive force, the "power to": the power to provoke discussion and communication; the power to acknowledge past injustices; the power to create a space of reconciliation.

Italian philosopher Gianni Vattimo also addresses the issue of power. In The End of Modernity, Vattimo presents for the first time his philosophy of weak thought in which he elaborates upon Heidegger's notion of Verwindung as a strategy for weakening traditional power relationships. This concept can be translated into "a going-beyond" that is both an acceptance and a resignation, while also a convalescence, a cure and a healing. ${ }^{12}$ He declares: "Verwindung indicates something analogous to Überwindung, or overcoming, but is distinctly different form the latter [...] because it contains no sense of 'leaving-behind' of a past that no longer has anything to say to us." 13

This philosophy of weak thought can be used to address the Algonquin's claim of

Asinabka. Rather than perpetuating an "overcoming" approach in the reclaiming of Asinabka, one where the Algonquin Nation wipes out colonial history in the same way that colonial history previously wiped out aboriginal history, I will explore a design strategy that will allow the Algonquins

\section{$\{$ Verwindung $\}$}

The lexical meaning of the term in German provides two shades of meaning: it is a convalescence (to heal, to be cured of a illness) and a distortion (to twist, and to the sense of a deviant alteration).

- Vattimo, Gianni (1988) in The End of Modernity.

\section{Idem: 11 .}

Lawrence and Enakshi, 2005: 130.

Dovey, 2008: 12.

Snyder, 1988: xxvi

13 Vattimo, 1988: 164 
to go beyond while simultaneously accepting, being resigned to and convalescencing from the colonial era and its errors and injustices. This theory will direct the design approach especially with respect to the relationship between the new construction and the existing ground configuration.

The design must acknowledge the Algonquins' resignation to and acceptance of the industrial ruins on the islands, but then twist the perception of them to heal the scars that they have left.

$$
\text { ....... }
$$

In Differences: Topographies of Contemporary Architecture, Ignasi de Solà-Morales interprets Vattimo's weakening philosophy in relation to the field of architecture under the heading "weak architecture" in his essay bearing the same name. Here de Solà-Morales demonstrates the failure of modern design in trying to establish a universal system for the aesthetic, literary, pictorial, and architectonic experience. ${ }^{14}$ By contrast, postmodern architecture, in conjunction with other arts, can no longer be regarded as a unitary whole but appears instead as "interweaving languages". ${ }^{15}$

The diversity of times, "as the overlapping of different layers", ${ }^{16}$ becomes also absolutely central in weak architecture. This theory is opposed to the continuous and controlled time of the classical age - a time with a beginning and an orderly and ordered expansion. ${ }^{17}$ Furthermore, ornamentation represents an acceptance of a certain weakness. De Solà-Morales supports Vattimo's theory on ornamentation, which claims that the latter becomes the central element of aesthetics, rather than an artistic surplus or excess as modernity has presented decorative art. ${ }^{18}$

Weak architecture also implies monumentality but not in the sense of monuments of the classical age in either geometric or ideological value. According to its etymology, the term monitu signifies "of recollection" ${ }^{19}$ or the recollection of the tradition. ${ }^{20}$ As John Snyder explains: "To remember and recollect the tradition, to think of it and to traverse it once again, does not mean to

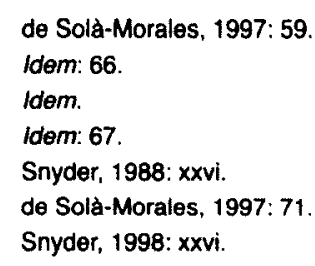


return uncritically to it." 21 It means that the recollection of tradition is not subject to nostalgia. In this sense the recollection of the Algonquin architectonic tradition will enable the Algonquin Nation to distort and weaken - but not erase - the colonial and industrial presence on Victoria Island.

.....

The development of the Asinabka centre will allow the Algonquin Nation to make tangible gains for its culture, as well as receive long due recognition from the residents of the Ottawa Valley. Specifically in the context of Ottawa, the industrial era embodies all the hardship inflicted by the "white peoples" on the Algonquin peoples, nation and cultural identity. Since being recognized by the NCC as the rightful owners of Asinabka, the Algonquins have expressed the desire to return the archipelago to its natural origin. 22 They have developed a schematic program and plan for these islands that includes the reforestation of the site and the demolition of many remaining industrial buildings. The spiritual leader of the Algonquins William Commanda has also called for the "undamming" of the Chaudière Falls in order "to regain access to this sacred site".23

Though their reaction to the reclaimed land is understandable, one cannot help but wonder whether such actions would not simply be perpetuating an attitude towards power relationships that is once again based on domination. I believe that a strategy based on resignation, acceptance and emancipation would be more appropriate to address the relationship between the Algonquin Nation and the contemporary situation. This strategy implies a much more positive and tolerant approach to power which seems to be in keeping with the Algonquin's own set of values - those of humility, truth, courage, honesty, respect and wisdom. ${ }^{24}$

21 Idem.

22 Circle of All Nations, 2006.

23 Idern.

24 Omàmiwinini Pimadjwowin, 2010 


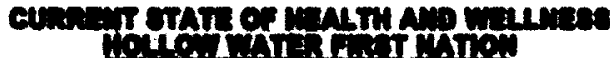

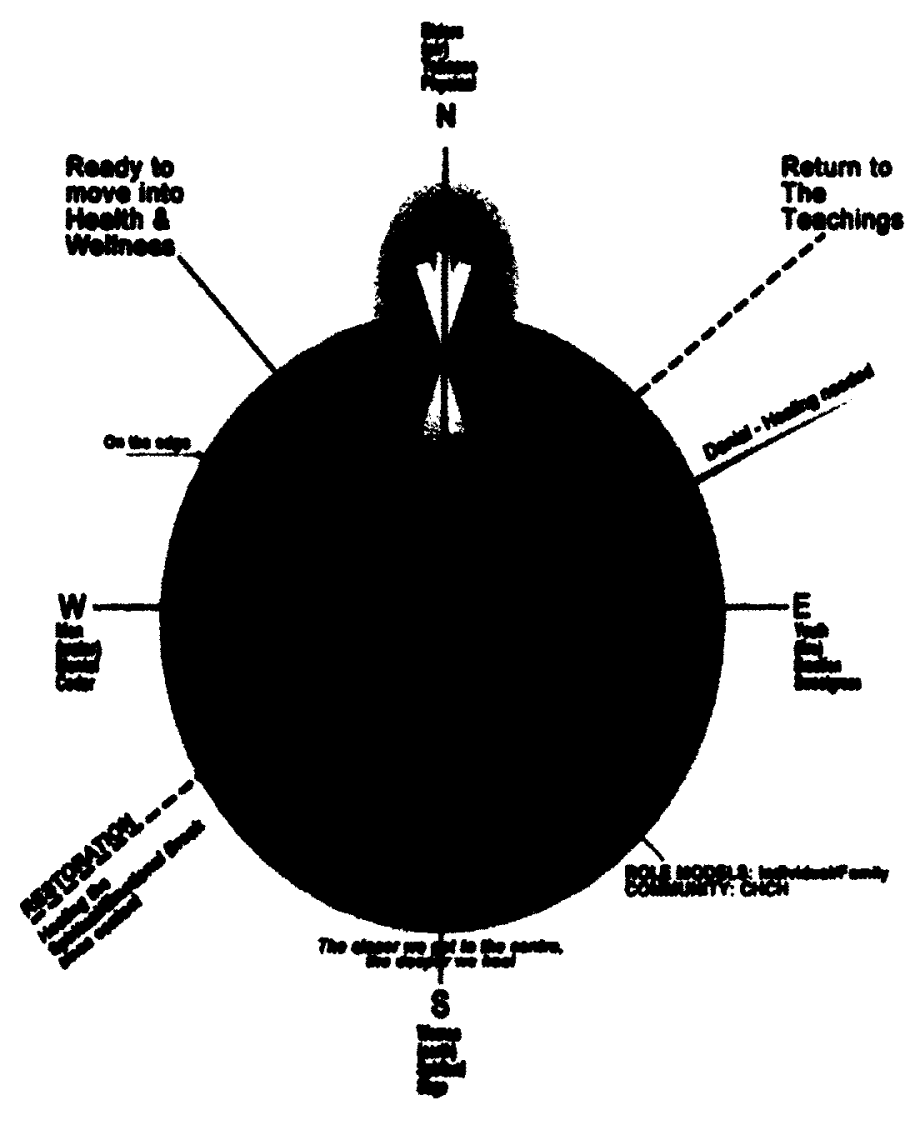

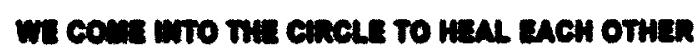

We hed tooether

Public Safety Canada (2010). Hollow Water First Nations. 


\section{Aboriginal Restorative Justice}

The Algonquin approach to power and justice has a lot in common with Vatimo's "weak thought" described above. The Algonquins believe in restorative justice, which emphasizes healing the harm done by an offence and rehabilitating the offender to avoid future harms or recurrences. Moreover, this healing process is holistic; in other words, it seeks a physical, emotional, intellectual, and spiritual balance 25 . The core of aboriginal restorative justice is generally a healing circle, which aims at developing a consensus on how to repair the harmful results of the offence ${ }^{26 .}$ Discussions between the offender, elders, and the victim of the offence and how it affected the victim and the community will lead to consensus. ${ }^{27}$ This healing circle can be formal (it is a recognized program by the Correctional Service Canada for Aboriginal offenders) ${ }^{28}$ or it can be informal (the healing circle can take place within communities or families when difficult issues are faced). 29

Criminologist Mylène Jaccoud states that: "The first healing circles were developed to try to halt the problems and the consequences of domestic violence and sexual abuse in communities." 30 According to Jaccoud, the circle of Hollow Water is certainly the most mature and structured healing process in Canada. This circle was born in 1983 through the initiative of people working in social services and its members were determined to find solutions to the problems faced in their community by youth struggling with substance abuse, vandalism, school dropout and suicide. Jaccoud explains that this group quickly discovered that the sexual abuse suffered by young people was the real problem underlying these excesses. Confronted by the magnitude of the problem, the group decided to establish a recovery program: the Community Holistic Circle Healing Program (CHCHP). This program embodies the Seven Sacred Teachings of the Algonquin people

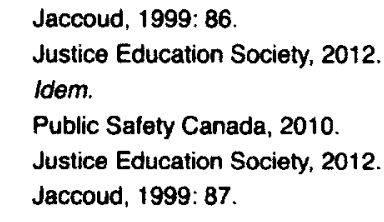

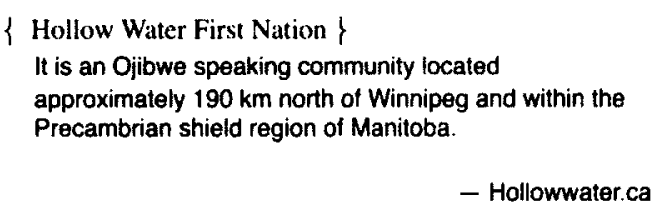

- Hollowwater.ca

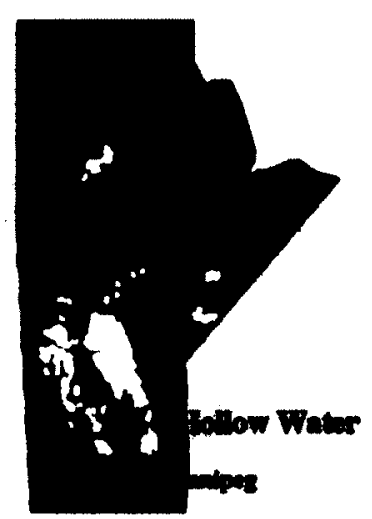


- courage, knowledge, respect, honesty, humility, love, and truth 31 - which are still today the foundations of formal and informal healing circles.

\section{Towards Decolonization}

Since the arrival of the Europeans in the seventeenth century, Aboriginal people of Canada have seen their land invaded, and their rights violated. The Algonquin Nation has suffered severely at the hand of non-Aboriginal Canadians. ${ }^{32}$ Early on, European explorers betrayed the Algonquins by revealing their location to the Iroquois, the Algonquin's enemies, in order to develop the fur trade route from the east to the west, and to the north towards James Bay. ${ }^{33}$ Simultaneously, Catholic missionaries tried to convert Aboriginals from Paganism to Catholicism, under the threat that only the converted ones would be recognized, supported and protected by their troops ${ }^{34}$. Early during the nineteenth century, settlers imposed industrial developments on the Algonquin territory while ignoring proclamations protecting Indigenous rights and lands. As Bonita Lawrence claims:

"Injustices continue to this day." 35 Despite the fact that decolonization is the centre of many essays and much research, regrettably we cannot affirm that we have entered a "post-colonial" era since colonialism is still affecting many Indigenous Nations throughout the world.

In the case of the Asinabka National Indigenous Centre, the power relationships are about to change. Finally acknowledged as the rightful owners of the land, the Algonquins will become those in the dominant position.

Public Salety Canada, 2012

See more information about European foreigners domination over Algonquins in Appendix 3.

Hessel, 1993: 38.

Idem: 42.

Lawrence, 2012: 31 


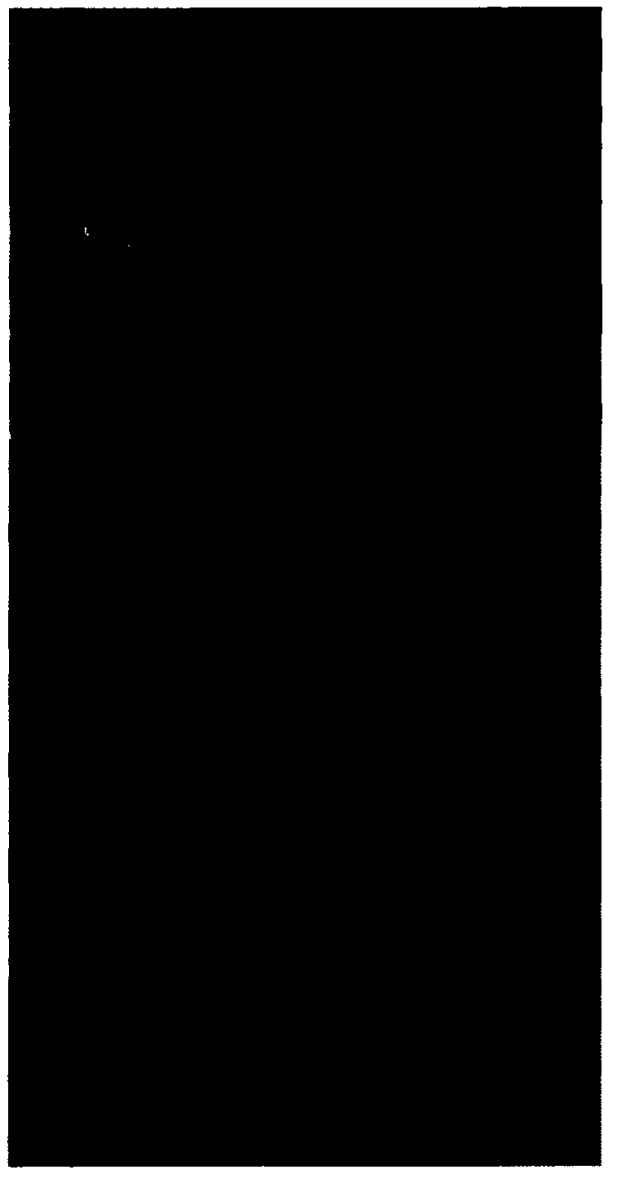

Commanda, William (2006) for the Circle of All Nations.

The Vision for Asinabk 


\section{Intentions}

I propose that a different strategy be taken with respect to the Algonquin recognition of

Asinabka. Rather than suppressing all references to "white people's" occupation of the site with the cloaking of the industrial heritage buildings within a monumental structure, might there not be a way to address the architectural injustices that have been inflicted on the site in the same way that the healing circle addresses offenders within the community? is it possible for a strategy of weak architecture to enable the Algonquin Nation to reconnect with Victoria Island in the built environment and the collective imagination?

Lighting the Eighth Fire aims to elaborate an architectural project in response to the Algonquin desire to construct a National indigenous Centre while respecting the significance of the industrial heritage to the National Capital Region and to the history of the Algonquin Nation. It aims to sensitize the communities to the importance of acknowledging past histories and heritage without according more significance to one over another. An end has to be brought to the modern tendency to want to overcome the past with something newer and better. It is understandable that the Algonquins wish to erase the traces of the history that harmed their nation. On the other hand, this approach will only help perpetuate the pattern of domination that they themselves have been fighting since the European arrival. The move to decolonization is more complex and involves more than denial.

$$
\text { (...... }
$$

The healing circle will play an important conceptual role in the design since the proposed building will represent negotiations and interactions between the victim, the Algonquins and the offender, the White people, as represented by the remaining industrial ruins. To emphasize the role of the healing circle, I have organized this thesis around the three main goals of the restorative justice system, which are acknowledgement, accountability, and engagement. Firstly, the victim represented by the Algonquin Nation - has to acknowledge and accept the harm. Simultaneously, its needs are identified in order to enable it to go beyond the harmful reality. Secondly, the offender 
has to take responsibility. In other words, the Canadian Government has to make efforts to understand the differences and diversity in First Nations people of contemporary times. Thirdly, the entire Algonquin community has to participate in the reconciliation process. Here the community is represented by the Ten Algonquin Communities extending between the provinces of Québec and Ontario. Finally, all these procedures will lead to an alternative design for the Asinabka National Indigenous Centre, which will be presented in the final Portfolio.

\author{
$\{$ Ten Algonquin Communitics $\}$ \\ These are the ten federally recognized Algonquin \\ communities: \\ Abitibiwinni, Québec: \\ Timiskaming, Québec; \\ Eagle Village (Kebaouek), Québec; \\ Wolf Lake, Québec; \\ Long Point (Winneway), Québec: \\ Kitcisakik (Grand Lac), Québec; \\ Lac Simon, Québec: \\ Mitcikinabik Inik (Barriere Lake), Québec; \\ Kitigan Zibi (River Desert), Québec: \\ - Piwàkanagàn (Golden Lake), Ontario.
}

- Algonquins of Pikwàkanagàn First Nation (2012) 


\section{Part 1 :}

\section{Omàmiwinni: The Victim}




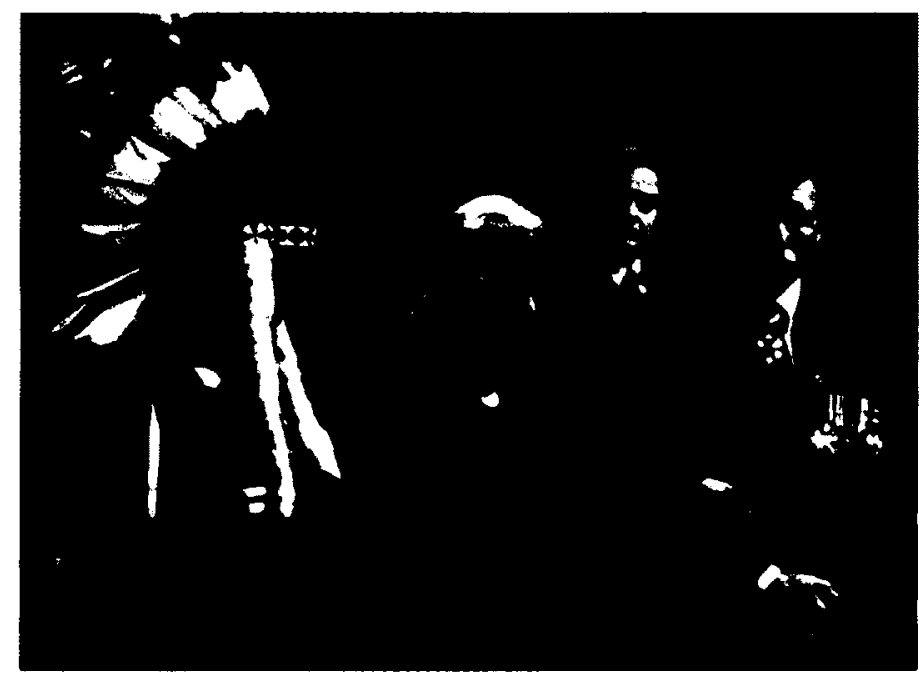

Hanson, Tom (November 4, 2005) for The Canadian Press.

William Commanda at a smudging ceremony in the Senate chamber together with former Algonquin chief Dominique Rankin and Senator Roméo Dallaire. 
I believe one of our most critical and immediate tasks in building an Indigenous resurgence is ensuring that the knowledge of our ancestors is taught to the coming generations. But, according to our intellectual traditions, how we do this is as important or perhaps more important than the product of our efforts. Nishnaabeg Knowledge Keepers believe that the processes we use for transferring that knowledge will either positively or negatively influence the outcome.

So, the first thing we must recover is our own Indigenous ways of knowing, our own Indigenous ways of protecting, sharing, and transmitting knowledge, our own Indigenous intellectual traditions. [...] Indigenous Knowledge systems have always been process-oriented systems of knowledge.

Leanne Betasamosake Simpson

Indigenous researcher and activist. (in her book Lighting the Eighth Fire: The Liberation Resurgence and Protection of Indigenous Nations, Winnipeg: Arbeiter Ring Publishing, 2008: 74.) 
In the healing circle, people who are experiencing various difficulties gather together to surpass problems, which can include trauma from the past, all forms of violence, addictions, incarceration, poverty, hopelessness, grief, and loss. ${ }^{1}$ In the case of Asinabka, the problem is the colonization by the Europeans of the First Nations. The primary objective of this circle is to acknowledge the harm, and to identify the victim's needs in order to enable restoration of respect, pride, freedom, and faith.

Indigenous Architect Douglas Cardinal, Elder William Commanda along with other Aboriginal Elders worked together to develop a vision for Asinabka. On the Circle of All Nations' website, Cardinal states that it was their wish that Victoria Island be a visible Aboriginal presence in Canada's capital. ${ }^{2}$ He also indicates that the Algonquins are looking to celebrate their individual gifts and diversity, and still recognize and respect their place within a Circle of All Nations. Cardinal explains that Elder Commanda is also looking forward to the lighting of the Eight Fire:

"[Elder Commanda] feels the steps to this future are few. First [the Algonquins] are to look within, so they know themselves best; recognize, acknowledge and forgive themselves their shortcomings and any failure to achieve their best potential; forgive others for any hardship and pain they may have caused them and their communities, and trust that this energy will transform them spiritually; recognize that their thoughts, words, and actions affect themselves, Mother Earth, and all creation. They are to embrace peace mindfully, listen to their minds, but trust their hearts above all. He feels this path will lead them to love, sharing, respect, responsibility, compassion, healing, justice and reconciliation." 3

The monumentality of Cardinal's proposal will indeed make visible the Aboriginal presence in Canada's capital, but I feel that there are other ways to achieve this end that might be more in keeping with the values stated above. Instead of expressing domination over the landscape and ruins, I propose to include the Union Carbide Mill ruins in a healing circle landscape, thereby creating a metaphoric dialogue between the victim, the Algonquin Nation and the offender, the Canadian Government (as represented by the industrial era remnants). I believe that, as with 
Vattimo's philosophy of weak thought, maintaining a dialogue results in a more genuine weakening of the power of the remaining industrial presence than if the site were to be returned to its precolonization condition.

Algonquins, such as author Paula Sherman, are aware of the benefits of such a positive and resilient approach. She claims:

"We are not working to find our way back to what we once were in the past, but are, instead, diligently struggling to bring forward those teachings, ceremonies, practices, and ways of relating that can help to rebuild a strong cultural base from which to resist contemporary colonialism and the cognitive elimination that accompanies the physical changes to our communities and bodies." 4

Weak thought seeks the remembrance and recollection of traditions, in the way that "to traverse it once again, does not mean to return uncritically to it". 5 Therefore, we will place in the forefront those teachings, ceremonies, and practices, as a canvas.

\section{Site:}

\section{Asinabka}

When talking about the victim, it is always in the context of the healing circle and its process towards reparation and reconciliation. The Algonquins, as all First Nations, are victims of European colonialism. Asinabka, the Algonquin sacred heartland, ${ }^{6}$ has also suffered the consequences of colonialism with its trees cut down for ship construction and pulp and paper production, bridges interrupting its landscape, and the dam's construction concealing the forcefulness of the falls.

Thus, Asinabka is sitting around the circle in the victim's chair together with the Algonquin people. -.......

The archipelago has always been a significant site for its occupiers; first as a sacred site and trading point for First Nations, and later as a lucrative industrial centre for colonial development.

$\{$ Asinabka $\}$

It is the Algonquin term for "place of glare rock", and consists of the place that includes the Chaudiere Falls, Victoria and Chaudière islands, and the lesser islands and shorelines on both sides of the Falls.

Anywhere that the spray from the Chaudiere Falls contacts the ground constitutes the body of Asinabka.

- Thumbadoo, Romola V. (2005) in Learning from a Kindergarten Dropout. 
Nowadays Asinabka possesses a national presence as it occupies a place along Confederation Boulevard, which assembles several prominent Canadian landmarks. ${ }^{7}$ In terms of ownership the current situation is complex. Victoria Island is administered by the National Capital Commission, and the latter recognizes the land to be Algonquin territory. ${ }^{8}$ Chaudière Island is a mix of federal land, managed by the Department of Public Works and Government Services Canada, and private land and industrial infrastructure owned and managed by Domtar Corporation. ${ }^{9}$ This complexity creates ambiguities for Aboriginals and non-Aboriginals alike to understand the legal situation of Asinabka.

$$
\text { -....... }
$$

The archipelago lies where the Ottawa River narrows between rocky escarpments on both sides of the river. The specificity of this site is marked by the presence of the Chaudière Falls - chaudière means "kettle." 10 The water level surrounding the archipelago can vary up to ten meters, and Victoria and Chaudière Islands rise to nearly twelve meters above the lowest water level. Geologically, the site is composed of limestone bedrock - as can be seen along the Ottawa riverbank - less than one meter deep, and covered with a sand and clay loam. ${ }^{11}$ This ground composition is very suitable for the coniferous forest, locally dominated by white and red pines that originally prevailed on Asinabka. ${ }^{12}$ The Great Fire of 1900 in Ottawa-Hull increased the growth of deciduous trees and shrubs, ${ }^{13}$ such as ash, oak and/or maple. Since that catastrophe the forest succession has not completed its cycle, so only few coniferous trees are found on the site.

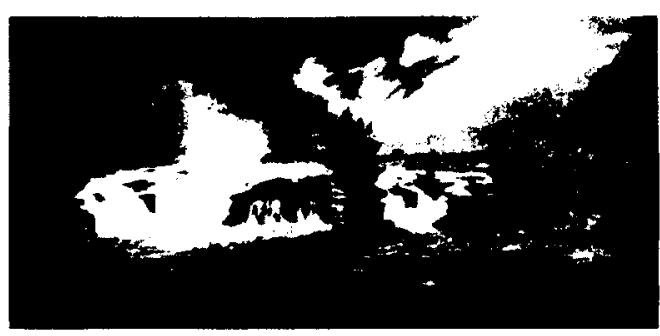

Woolford, John Elliott (1821). Chaudières Falls at Ottawa

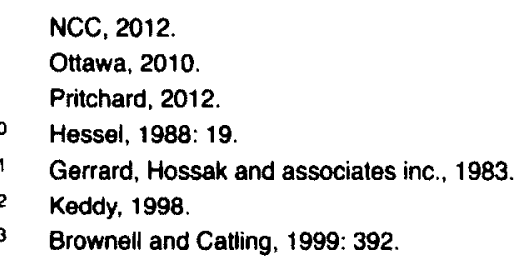




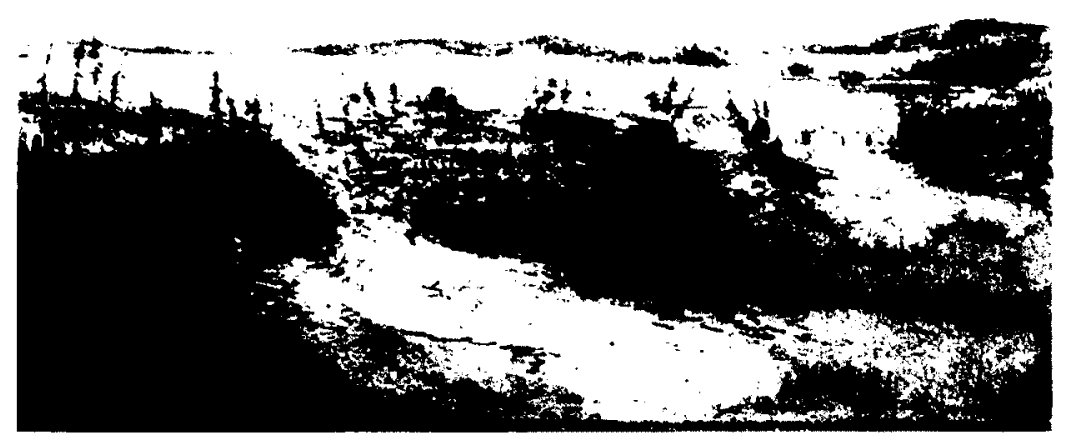

Colvilie, Charles John (1838). View of the Chaudière Falls at Bytown.

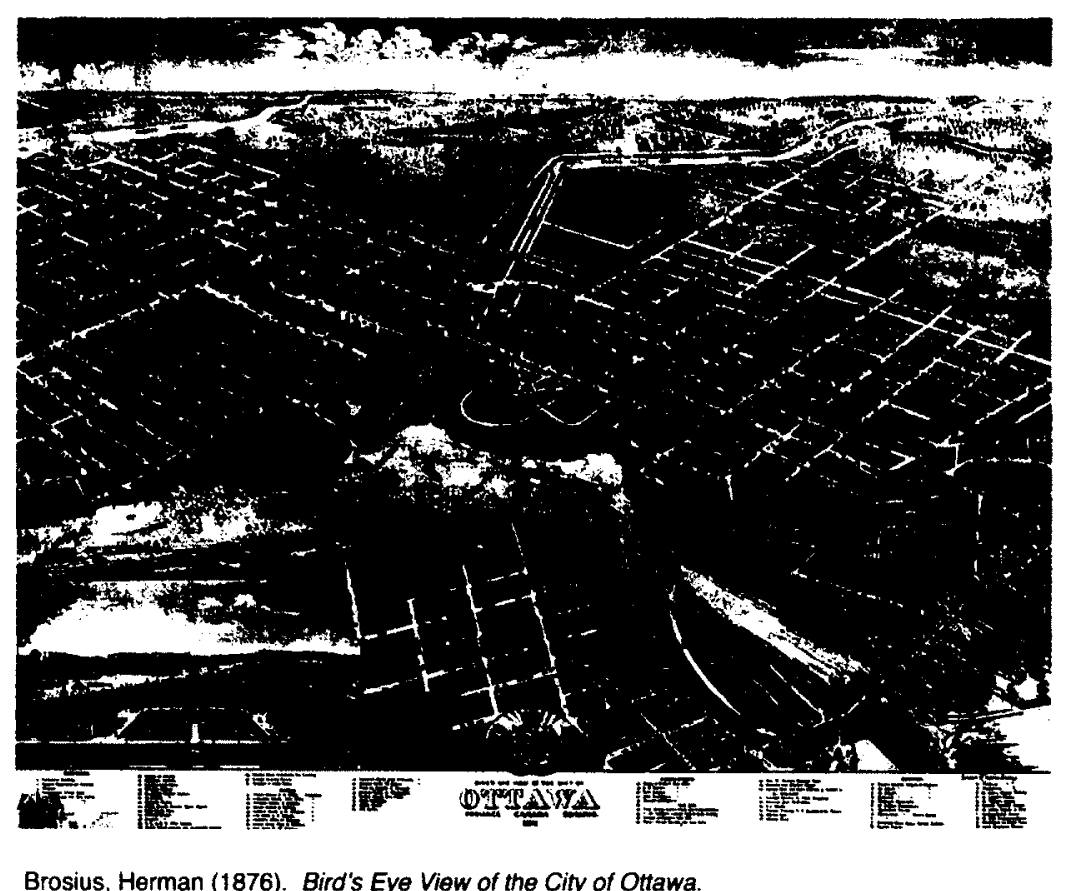


The Chaudière dam was constructed in 1910 to take advantage of the potential for power generation from the river water and standardizing the water level. ${ }^{14}$ The waterfall, in the shape of a horseshoe, is about ten meters high. People referred to this waterfall as the "Grande Chaudière" (big cauldron), distinguishing it from the "Petite Chaudière" (little cauldron), which is now under the Domtar buildings on the Québec side of the river. Other significant constructions are two bridges: the Chaudière Bridge, previously known as the Union Bridge, built in 1828 and now crossing Chaudière and Victoria Islands, ${ }^{15}$ and the Portage Bridge, built in 1973 that splits Victoria Island in two. ${ }^{16}$

Victoria and Chaudière Islands contain the vestiges of the National Capital Region's industrial core. Due to the establishment of the first settlements, the archipelago became a prized location for the lumber industry during the nineteenth century, and for the puip and paper industry during the following century. Following the Gréber Report of 1950 and its recommendations to remove industries from the city core, the 1960's gave way to the demolition of many industrials buildings mainly located on Victoria Island, which returned the site to a more natural landscape.

Some structures still remain: Hydro Ottawa's Generating Stations No. 2 and 4 built between 1890 and 1900; the Ottawa Electric Railway Company Steam Plant which now host Vertical Reality, a rock climbing gym; the Bronson Company Office currently labelled as the Ottawa-Hull Naval Association; and the ruins of the Union Carbide Mill built in 1900 to produce calcium carbide and acetylene gas. ${ }^{17}$ Since the year 2000 the open spaces of Victoria Island have seen the establishment of Aboriginal Experiences on its shore, a seasonal attraction that celebrates Aboriginal culture, located near the early spiritual site of the Algonquin Nation.

In addition to the remaining industrial buildings, the landscape of Asinabka currently presents many vestiges of the 1970's brutalist period that promoted concrete as the material of choice for stairs, terraces, ramps, and retaining walls.

14 The first dikes were built to harness this kinetic energy for local industries in the 1810 's. Canadian Museum of Civilization, 2010.

15 Bytown Museum, 2012.

16 Idem.

17 Parks Canada, 2002.

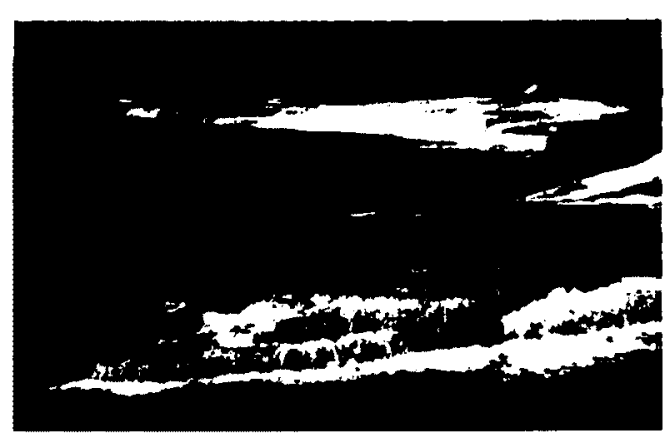

Foster, Harry (April 14, 2003) for the CMCC. The Chaudière Falls [and surrounding dam]. 


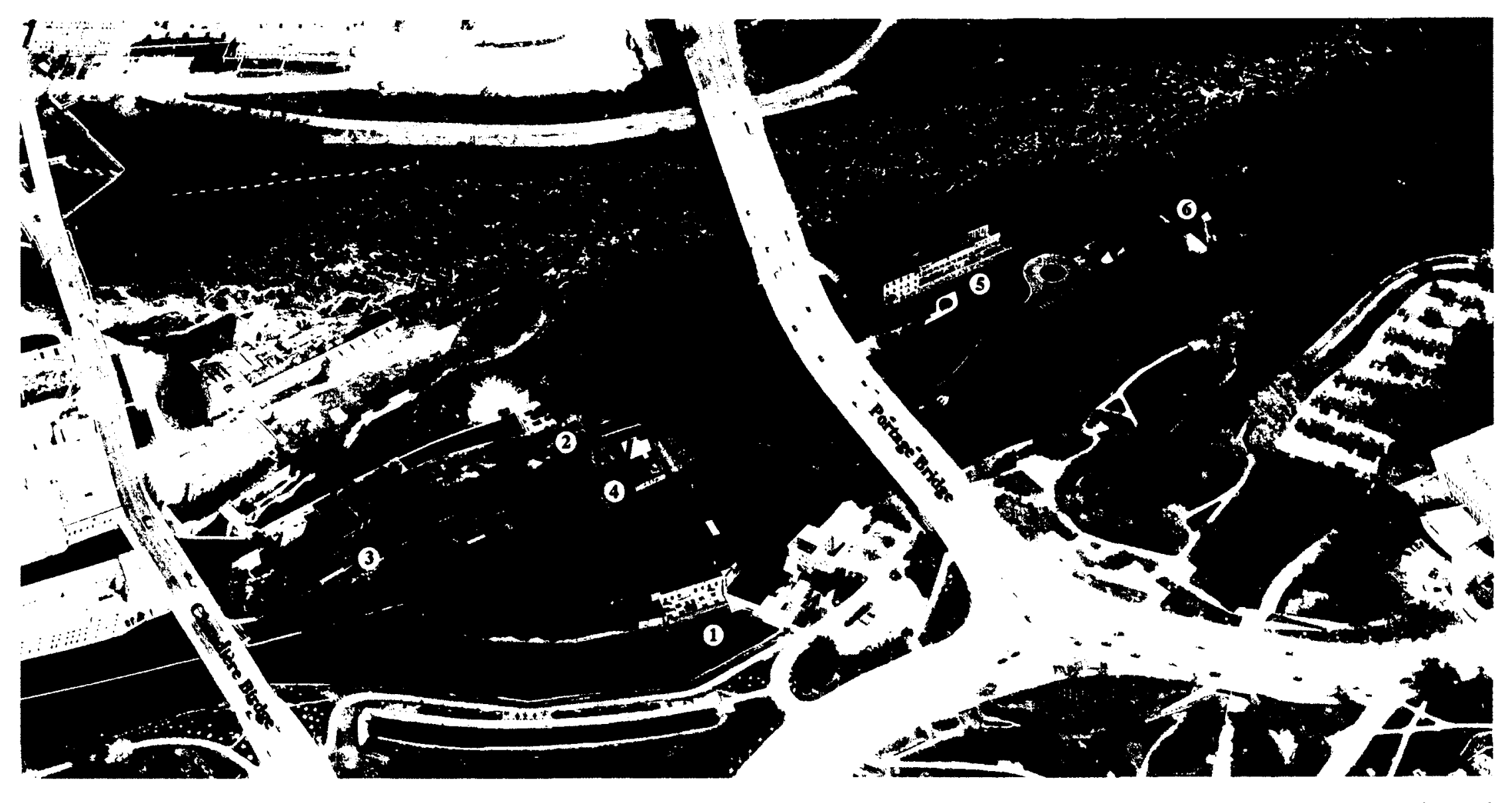

(1) Hydro Ottawa's Generating Station No. 2

(2) Hydro Otlawa's Generating Station No.

(3) Ottawa Electric Railway Company Steam Plant/Nertical Reality;

(4) Bronson Company Olfice/Ottawa-Hull Naval Association;

(5) Union Carbide Mill;

(6) Aboriginal Experiences. 


$$
\text { - . . . . }
$$

The demolition and removal of all of these structures would not be in line with the reconciliation process objective. Such actions would represent an attitude of overcoming rather than one of accepting, twisting and healing. Instead I propose that these structures remain and that the healing process of Asinabka take place by natural actions. Nature never dominates; rather it grows, flourishes, and gains strength gradually. The roots of new indigenous trees, shrubs and herbs will crack and weaken the concrete surfaces leading to their decay. This gradual transformation will illustrate to occupiers and visitors of the National Indigenous Centre that such brutal installations do not belong on Asinabka, that Mother Earth always has the last word. This same approach will be used for every design solution connected with the landscape of Asinabka: the transformation of the layout of Portage Bridge and the connections of a new structure to the existing industrial ruins.

\section{Program:}

\section{National Indigenous Centre}

The decision to develop and build a National Indigenous Centre on Asinabka, the heart of the National Capital Region, is in line with the resurgence of Indigenous knowledge and traditions within First Nations. Leanne Simpson proclaims: "Recovering and maintaining Indigenous world views and applying those teachings in a contemporary context represent a network of emancipatory strategies Indigenous Peoples can employ to disentangle themselves from the oppressive control of occupying state governments." 18

$$
\cdots \cdots \cdots
$$

In 2004, the Federal Government, as represented by the National Capital Commission (NCC), along with Elder representatives from the ten Algonquin communities of the Kiji Sibi Valley entered into an agreement which stated that Asinabka, Algonquin sacred territory, would be dedicated to the

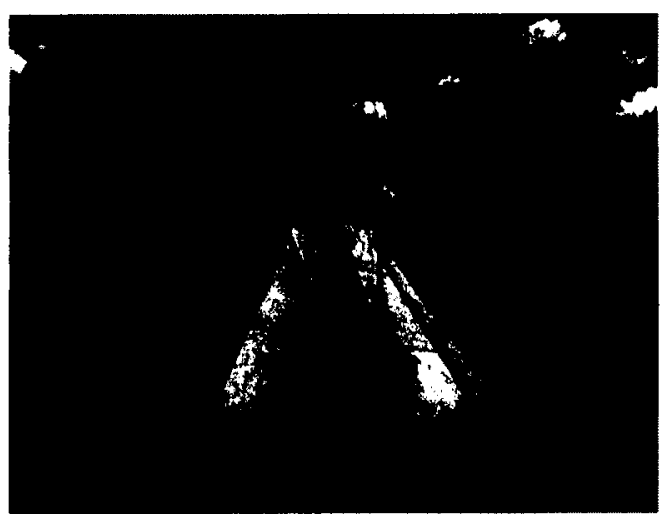

Peltier, Josh (2004). IInstallations for Aboriginal Experiences].

18 Simpson, 2008: 15. 
representation of Indigenous spirituality, culture and traditions. ${ }^{19}$ Thus, the NCC incorporated the Indigenous Centre into its twenty-five years master plan. Elder Commanda describes their intentions:

\begin{abstract}
"We propose the establishment of the Asinabka National Indigenous Centre. It is envisioned as a site to provide spiritual sanctuary and to advance dialogue on healing and strengthening Indigenous Peoples; to showcase the culture and heritage of First Nations, Inuit and Métis Peoples in a world class setting of interest and relevance to local residents and national and international visitors: and to serve as a think tank for environmental stewardship and peace building." 20
\end{abstract}

This agreement took the form of a Trust arrangement under which both parties agreed to the purpose of the project. The agreement can only be modified if the NCC and the ten Algonquin Elders give their permission. ${ }^{21}$ This Trust arrangement enabled the Chief of Attawapiskat, Theresa Spence, to pursue her hunger strike on Victoria Island as part of the movement Idle No More. As protector of Canada's national heritage, the NCC had always kept an eye on the activities taking place on Victoria Island. It let Chief Spence and her supporters protest peacefully since the island was now recognized as Indigenous land.

For a few weeks Idle No More was in the news; Aboriginals were able to get the attention of non-Aboriginal Canadians by protesting in front of Parliament Buildings, and with road and railway blockades. By contrast, the activities on Victoria Island that have been taking place within the palisade of Aboriginal Experiences have not had the same visibility. To rectify this situation, in addition to the creation of a dialogue with the existing industrial ruins, it is important that the new National Indigenous Centre enter into an architectural dialogue with the Parliament Buildings. This centre has to provide a setting for First Nations to express their opinions, participate in discussions, and protest for the recognition of their rights.

Ottawa, 2010

20 Idem.

idem.

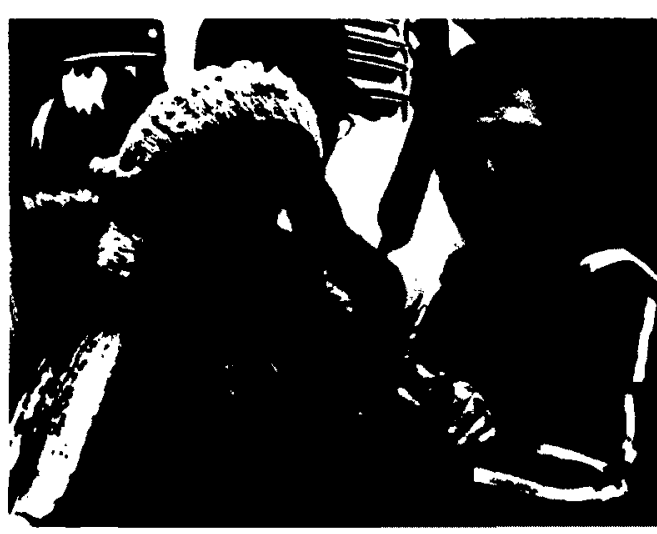

Forget, Andre (January 4, 2013), for QMI Agency. Theresa Spence at a press conference on Victoria Island. Ottawa.

$\{$ Idle No More $\}$

This movement is about redressing the damage we have done to ourselves and the environment, and preventing more of the same It is focusing of aboriginal youth and education, human solidarity, love, and rights protection.

- Idllenomore.ca 
Elder Commanda and the NCC commissioned Architect Douglas Cardinal to work with the

Algonquin Elders to develop the program and design of the Indigenous Centre. Commanda along

with the architect discussed and elaborated with other Elders the need for enabling the resurgence

of Indigenous Knowledge. Together they set up the goals and the program for the project:

"Firstly, it will, within its core vision, support the healing of Indigenous Peoples, the healing of relationships with others, and the healing of relationships with Mother Earth. It will do so by strengthening indigenous identity, supporting the revitalization of language, education and cultural expression, providing strategic leadership on social issues which would strengthen indigenous communities, and building the interconnectedness of indigenous peoples with each other, with other parties and with Mother Earth.

Secondly, the Centre will provide a national stage for celebration of elements central to Aboriginal history and culture including spiritual and ceremonial, arts and crafts, education, medicine, traditional knowledge and will include archival, library and research functions. The Centre will actively engage children, youth and elders in developmental activities of the Centre, and will have as an objective the building of pride and knowledge, and communication of Aboriginal life.

Finally, the Centre will share with Canadians and people around the world the values and ideology of Indigenous Peoples. Activities included under this purpose would include cultural sharing, inter-racial activities, peace-building, international relations, museum, gallery, convention, meeting and activity centres.

Broadly, this Centre would contribute to the education, communication and understanding of Aboriginal culture, and its location in the Capital would give it the unique opportunity to be experienced by visitors from across Canada and around the world. It would add a unique dimension to the expression of Canada's cultural richness and diversity and a corresponding statement of recognition and reconciliation for the Aboriginal people of Canada." 22 
The Algonquin Nation will serve has the host nation, welcoming all First Nations, Inuit and Métis to develop and animate the Asinabka National Indigenous Centre in the spirit of inclusion, sharing and exchange.

$$
\text { - . . . . }
$$

The priority of the Indigenous Centre is to put Native spirituality, culture and traditions at the forefront. It will be a cultural centre and an Indigenous knowledge, living and sharing centre. Leanne Simpson describes the importance of living the Indigenous ideology: "The best way (perhaps the only way, according to some Knowledge Holders) to preserve Indigenous Knowledge systems is to live Indigenous Knowledge systems by creating a generation fully connected to the land, our languages, and our Knowledge Holders and trained in the artistry of the oral/aural tradition." 23

According to Elder Commanda, the centre will be a "spiritual healing centre to unify and strengthen Indigenous peoples," and a "centre for all nations to share the values and ideology of Indigenous peoples." 24 It will have meeting rooms, a conference centre, a concert space, a United Nations meeting space, archives, a library, a historic research centre, a media centre, a youth museum, galleries, studio spaces, a gift shop, restaurant, greenhouse and gardens.

$$
\text { -....... }
$$

In developing of this counterproposal, I aspire to interpret the same program and intentions elaborated by the Algonquin Elders and the NCC. A group of knowledgeable people has chosen the general requirements for the Indigenous Centre. The Architecture of the Indigenous Centre will be the vehicle for the realization of those ambitions, and will focus on the needs of Aboriginals moving towards decolonization.

23 Simpson, 2008: 82

24 Ottawa, 2010. 


\section{Part 2 :}

Àyàwashomàn: The Offender

Accountability 


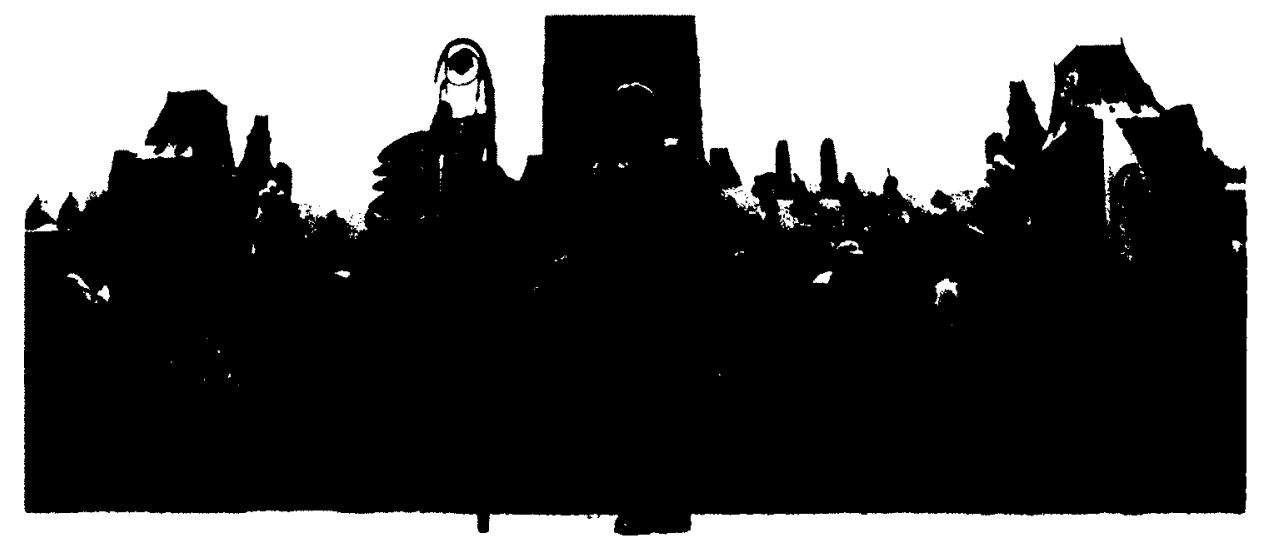

Kilpatrick, Sean (January 28, 2013), for The Canadian Press. Native dancers rally during 'Idle No More' gathering on Parliament Hill in Ottawa. 
Perhaps the most potent symbol of our disempowerment is the manner in which Canada has not only disregarded our nationhood to the point where it appropriated our lands to build its capital city on, but has absolutely refused to address this in the land claim talks that have been going on for the past ten years [...].

For me, the Parliament Buildings are a constant reminder of injustice perpetuated by bitter division and the illegal and immoral domination of one nation over another.

\section{Heather Majaury}

Algonquin Artist (in her essay "Living Inside Layers of Colonial Division: A Par of Algonquin Story", in Attantis, Volume 29.2 Spring 2005.) 
It is crucial in the healing circle process that all members, the victim, the offender, and the members of the community, participate and respect the restorative process. As Native storyteller and writer Joseph Bruchac explains: "[To be sitting around a circle means that] everyone is the same distance from the centre; everyone can see each other, and everyone is sitting at the same height." 1 He adds: "It is hard to hide in a circle; therefore, when you are part of a circle you are responsible and part of everything." 2 This accountability also looks to the offender to take responsibility for his harm and its direct consequences.

In the case of Asinabka the remaining industrial ruins represent the figure of the offender. More broadly the offender is the Canadian Government since the latter is the political embodiment of colonialism. On Asinabka industrialization is the result of a thriving timber and lumber industry together with the pulp and paper industry, which exploited the kinetic energy of the Chaudière Falls and altered the physical aspect of the site forever. As Bonita Lawrence declares: "The wealth of Canadian society is clearly predicated on many years of Algonquin impoverishment." 3 Settlers developed these industries to the detriments of Indigenous rights and treaties with the British Crown. ${ }^{4}$ They imposed their rules and laws on Aboriginals, leading to the loss of First Nations sovereignty. Leanne Simpson describes the balance that First Nations were living during precontact times

"In the times prior to colonization, Indigenous peoples lived in independent, sovereign nations governed by complex political social systems. Rooted in the land, with strong spiritual and religious foundation, these systems ensured our citizens were taken care of and that contentious issues were resolved in a peaceful and just manner." 5

Recovering this independence, sovereignty and balance that survived for thousands of years would go a long way towards decolonization. First, however, the Canadian Government has to

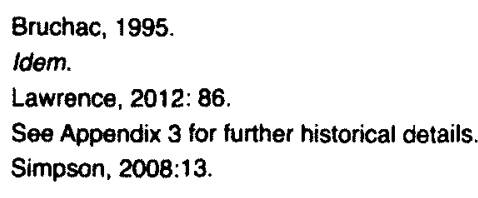


acknowledge the harms it has done against First Nations, and has to take responsibility for repairing those harms.

The more the Aboriginals fight against assimilating policies the more they are making themselves visible, thereby sensitizing the population. Some interventions have been made by the Federal Government in reaction to Aboriginal claims. The Federal Government initiated the recognition of the rights of First Nations in 1982 when Pierre-Elliott Trudeau created the Canadian Charter of Rights and Freedoms, which amended the previous Act of $1867 .{ }^{6}$ More recently in June 2008, through the establishment of the Truth and Reconciliation Commission of Canada, the Federal Government has made formal apologies to former students of residential schools, their families, and communities. On the Commission's website we can read about its mandate: "This Commission hopes to guide and inspire First Nations, Inuit and Métis peoples and Canadians in a process of truth and healing leading towards reconciliation and renewed relationships based on mutual understanding and respect." 7 This Commission gives us hope that Canada will become a nation equitable to everyone.

$$
\text { -..... }
$$

Still much work has to be done. Aboriginals continue to experience inequity, underrepresentation and injustices. In the United Nations Human Development Report of 2004, which is used to assess standards of living, Canada was ranked $7^{\text {th }}$ in the world - out of 174 countries at the time. When this formula is applied to registered Aboriginals, Canada is ranked $48^{\text {th }}$ in the world. ${ }^{8}$ The study explains that poverty, infant mortality, unemployment, morbidity, suicide, criminal detention, children on welfare, women victims of abuse, child prostitution are all much higher among Aboriginal people than in any other sector of Canadian society. True reconciliation will be possible only when the Canadian government takes responsibility and brings reparation to Indigenous communities.

\footnotetext{
Université Laval, 2000

Truth and Reconciliation Commission of Canada, 2013.

CBC News, 2005
}

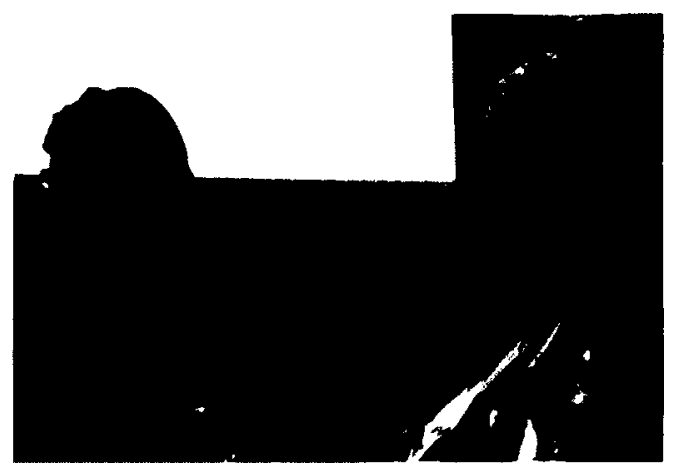

Cole, Yolande (February 24, 201).

Commissioner Marie Wilson and Justice Murray Sinclair during a press conference on the Truth and Reconciliation Commission's interim report.

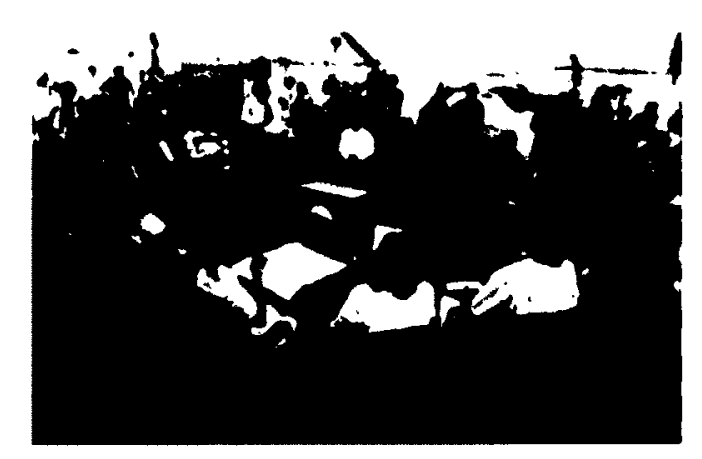

Woods, John (January 21, 2011), for The Canadian Press. Sharing circle at the first national event of the Truth and Reconciliation Commission in Winnipeg.

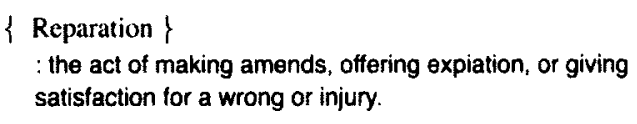

- Merriam-Webster Dictionary. 


\section{Acceptance:}

Awareness of Colonialism

Since the establishment of settlers in Canada, dominating laws and policies have marginalized First

Nations while forcing them to join and participate in a system alien to them. Algonquin scholar

Paula Sherman explains:

"The [implementation of foreign social and political structures] have led to policies that enabled Europeans to profit from our lands and resources while economically and politically marginalizing us to the fringes of our own territory. These policies not only worked to jeopardize our autonomy and jurisdiction, they also attempted to colonize our minds and transform our perceptions of our relationships with the land and even with each other. [...] These policies have had an impact on our psyches and our ability to resist colonialism, $[\ldots]$ and, as a result, we often lack confidence in ourselves [... $]^{n} .9$

These impacts are still present within First Nations since minimal actions have been taken by governments, municipal, provincial and federal, to reverse Indigenous colonization.

$$
\text { ........ }
$$

One of the most alienating actions implemented by the Federal Government was the creation of the Indian Act that was supposed to 'protect' Indigenous rights. In fact, this act contains policies and programs that are designed to 'control' the lives of Indigenous peoples rather than protect them as it claims. Ellen Gabriel states in her essay Sovereignty and Resistance:

"Since its inception, Aboriginal peoples have been resisting the imposed laws that were designed not only to control but to destroy the social, spiritual and political fabric of Aboriginal nations. One need only look to the history of residential schools in Canada to see the manifestation of these acts of genocide against Aboriginal peoples.

$[\ldots]$ \{ndian Act $\}$

It is the primary piece of federal legislation that governs Status Indian and most aspects of their day-to-day lives including governance, Ban membership and elections. home ownership, land use and ownership, taxation, use home ownership, land use and ownership, taxation, use Government of Canada.

The federal government's self-defined authority to create the Indian Act was found in the 1867 Constitutional Act which declared that Canada would be responsible for 'Indians and lands reserved for Indians.

- Lynda Gray (2012)

9 Sherman, 2008: 111-113 
Freedom and democracy are two factors in a nation's life that perpetuate a healthy growth of its people. Oppression has been the constant in Aboriginal peoples' relationship with Canada. It has also been instrumental in the destruction and loss of peoples' traditions, language, spirituality and political structures. Aboriginal peoples will continue to fight and resist, utilizing the means available to them, until a relationship based upon mutual respect, integrity and honesty is achieved. Until then, the world will see more acts of resistance to achieve a form of sovereignty that will allow our nations to flourish." 10

Asinabka has been witness to several Indigenous resistance efforts. In 1974 the Indian People's Caravan, including many Natives from across Canada, headed to Parliament Hill. Participants subsequently established the "North American Indian Embassy" in the former Carbide Mill on Victoria Island, which lasted from September 1974 to March 1975." A fallen oil lamp caused the mill to burn and to lose its rear roof and wall. The purpose of this embassy was to bring public attention to poor living and health conditions on Indian reserves. The demands of the protesters included land claims and better medical care, education and economic development. ${ }^{12}$

The engagement of the industrial ruins as a participant in the National Indigenous Centre will be a continuation of this movement of resistance that started decades ago, however the contemporary centre will represent cooperation and collaboration between Aboriginals and governments rather than a "symbol of confrontation" as in $1974 .{ }^{13}$

$$
\text { ........ }
$$

Moving towards decolonization is complex since the Canadian and Provincial governments misunderstand the foundation of Indigenous sovereignty. For example, the creation of Upper and Lower Canada in 1791 fractured the Algonquin homeland. White settlers determined the Ottawa River as a boundary, and ignored the reality that this waterway is the heart of the Algonquin Nation for fishing, transportation, trade, gathering and spiritual ceremonies.

10 Gabriel, 2009

11 Moore, 1974: 1.

12 The Citizen, 1975: 14

13 Nanji, 1975: 7
\{ Indian People's Caravan

This movement was in line with the American Indian Movement (AIM) of 1972 in the United States. Russell Means, Native Sioux at the head of the AIM, called attention to the nation's history of injustices against Indigenous peoples.

- Associated Press (2012)

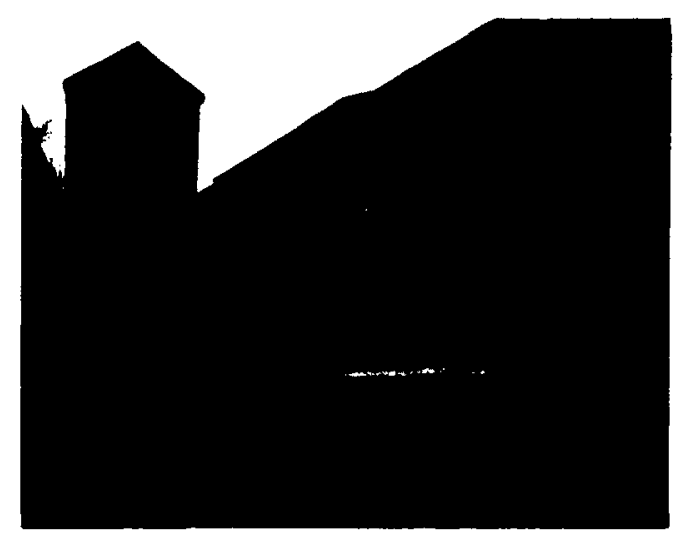

Lamothe, Sophie (November 14, 2011). Rear View of the Union Carbide Mill Ruins. 
Since the Algonquin Nation is divided between two provinces, the governments are having trouble understanding the relationships that exist within the entire Algonquin Nation. One of the best examples relates to the Golden Lake land claim - also know as the Algonquin of Ontario land claim. This land claim process has been undertaken in eastern Ontario by the Algonquin reserve Pikwàkanagàn - Golden Lake - reclaiming $36,000 \mathrm{~km}^{2}$ and affecting more than thirty municipalities and counties. ${ }^{14}$ For over twenty-two years, negotiations have been taking place between the Federal Government, the province of Ontario and the Algonquins of Ontario. These negotiations are due to conclude soon, ${ }^{15}$ but the Kitigan Zibi band from the province of Québec is looking to stop the Golden Lake land claim since "the land belongs to all Algonquins and should include all of the ten bands." 16

While many communities across Canada long ago signed land-sharing treaties with the British Crown and the Government of Canada, much of the Ottawa River Valley was never officially ceded, and according to the Native bands that occupy the land, it still belongs to them. "We have never surrendered our rights, by treaty or otherwise," ${ }^{17}$ says Algonquin Chief Terence McBride of Timiskaming. "What we need today is a recognition of those rights, and we are presenting this evidence to ensure effective consultation on matters affecting our interests."

According to Chief Gilbert Whiteduck of Kitigan Zibi: "The Government would be more likely to accommodate land claims if all Algonquin communities could find a way to work in tandem for their combined interests as our ancestors did." He adds: "There is no doubt that if the [Algonquin] Nation as a whole - all ten communities - were really pulling together, we could go such a long way. Not only with claims, but on so many other things." 18 For the moment, however, Gilbert Whiteduck is consulting with lawyers to figure out how to stop the Golden Lake land claim from proceeding.

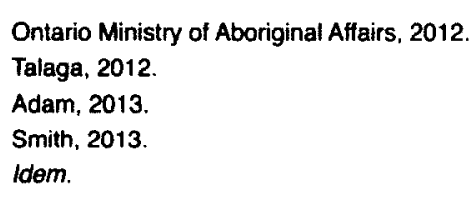




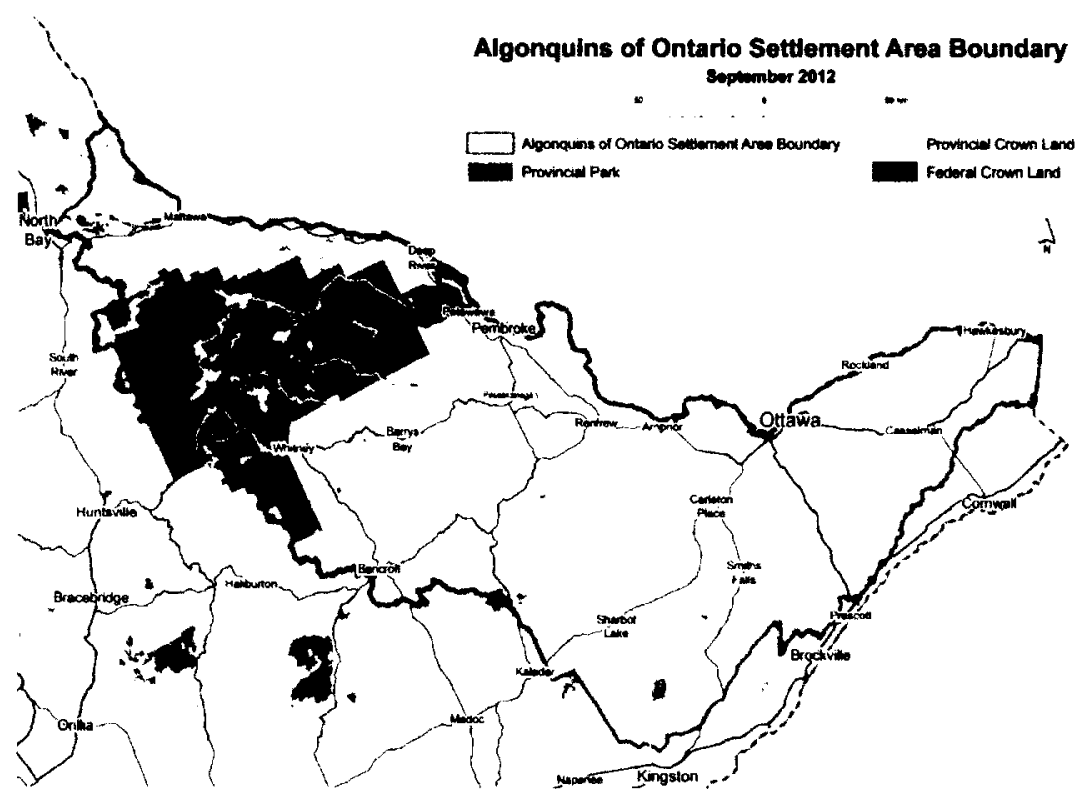

Ontario Ministry of Aboriginal Affairs (2012). Algonquins of Ontario Settlement Area Boundary. 
On the other hand, Ontario's chief negotiator Brian Crane says the province accepts that Québec Algonquins have legitimate claims, and the current draft agreement in principle states that it is not dealing with the rights of the Québec Algonquins in Ontario. ${ }^{19}$ But Jean-Guy Whiteduck, band manager and former chief of Kitigan Zibi, declares those guarantees fall short, and Ontario will ultimately have to deal with his people directly, ${ }^{20} \mathrm{He}$ adds: "The government wants certainty on this process. Certainty will be when we agree, when all the other Algonquin communities agree too. They can't get certainty just with Golden Lake," 21

$$
\text { ......... }
$$

The land claim process is long and complex because the governments have trouble understanding that Aboriginals have and maintain a different cultural existence from mainstream Canadian society. Since Aboriginal and non-Aboriginal Nations are sharing Canadian land, the governments have to be more receptive to the Indigenous way of governing. Acknowledging colonialism would be a step towards approaching Indigenous claims in the Indigenous way, i.e. in an egalitarian and inclusive way. ${ }^{22}$ First, however, Canadian governments have to acknowledge the shocking living conditions, inequality and racism that many of Aboriginals still endure.

\section{Reparation:}

\section{Governmental Funding}

Canada will celebrate its Sesquicentennial, the $150^{\text {th }}$ anniversary of Confederation, in 2017. In the planning of this celebration, some speakers are addressing the importance of acknowledging

historic wrongs. Peter Dinsdale, chief operating officer of the Assembly of First Nations, challenges delegates to work towards the recognition of Aboriginal Nations as first order governments in 2017.23 Dinsdale states:

9 CBC News, 2013.
Idem.
Idem.
Gray, 2012: 30-32.
IPAC and MASS LBP, 2010.


"Until Confederation, the Crown regarded North America's Aboriginals as sovereign nations. After 1867 , they became subject nations and later, subject peoples. The Sesquicentennial is an opportunity to create a new relationship with Canada's First Nations, Metis and Inuit and restore their status as first order governments." ${ }^{24}$

The celebration organizers have agreed that a 'homage' to Aboriginal culture is not enough to address the very real issues of understanding, exclusion and poverty. Rather, they advocate a public dialogue on the contemporary significance of Canada's three founding peoples, Aboriginals, French and British. ${ }^{25}$

According to Peter Dinsdale, First Nations are thinking of the year 2017 more as the $250^{\text {th }}$ anniversary of the 1763 Royal Proclamation than as the $150^{\text {th }}$ anniversary of Confederation. "I think the Royal Proclamation has much standing in the eyes of First Nations. I think they see Canada, in many ways, as a successor state to Great Britain. And I think for First Nations, we've been trying to get back to that nation-to-nation relationship ever since." 26

The completion of the "long-dreamed-of aboriginal centre on Victoria Island" 27 would represent a fitting way to celebrate this nation-to-nation relationship as proposed by Dinsdale who has the support of many Algonquins and Native people. Moreover, Band Councillor for Kitigan Zibi and Executive Director for the First Nations Confederacy of Cultural Education Centre, Claudette Commanda, believes that the Government of Canada should subsidize the construction of the Asinabka National Indigenous Centre in order to make reparation to Native peoples. ${ }^{28}$ She suggests that the centre should be federally funded, but Algonquins would both administer the centre, and manage the funds.

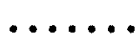
$\{1763$ Royal Proclamation $\}$
This proclamation marked the end of the Seven Years' War, affirming Britain's conquest of New France but also its recognition of Canada's Aboriginal Peoples as members of proud, independent, self-governing nations.

- Peter Dinsdale (2012) in "Sadness in the celebration" for the Citizen.

24

25 Idem.

26 Boswell, 2012

27 Idem.

28 Commanda, interview May 1 st, 2013 
This funding process is in line with a global movement from settler-based societies to reconcile with Native Nations. For example, the French Government paid for the development and construction of the Tjibaou Cultural Centre for the Kanak people of New Caledonia. The French Government commissioned Renzo Piano Building Workshop for the development of this cultural centre, thus leveraging the abilities of the architect to enhance the cultural agency of the Kanak. As Lisa Findley writes in her book Building Change: Architecture, Politics and Cultural Agency.

"In this way, the building became a significant addition to the emergence of the Kanak as serious and important cultural participants in New Caledonia and in the Pacific region. It made them visible in a profoundly new way - a way

understood in a global context and in the global language of architecture." 29

The Tjibaou Cultural Centre is the fruit of the averted civil war of the 1980's and the signing of the Matignon-Oudinot Accords. The leader who negotiated the Accord for the Kanak was Jean-Marie Tjibaou who argued unrelentingly that cultural production and presence was essential to Kanak political inclusion as explains Findley. ${ }^{30}$ The Accord included, at the insistence of the Kanak, the support and development of Kanak culture as an integrated par of the dominant French New Caledonia culture. They consequently established the Agence de développement de la culture Kanak (Agency for the Development of Kanak Culture). Findley states: "Tjibaou was adamant that this Agency should have a cultural centre, and that it must be located in Noumea, the mostly white capital, [...]." ${ }^{n 1}$ The mandate of the centre would not only be the presentation and preservation of what was left of traditional Kanak culture, dance, art and language, but would rather focus on its development and interaction with other Pacific Islanders and the world, Findley says.

$$
\text { ....... }
$$

The parallel between the funding and development of the Tjibaou Cultural Centre and the Asinabka National Indigenous Centre is evident. In Canada, Aboriginal Chiefs and Elders recommended to Ottawa the creation of a program designed to protect, enhance and develop Indigenous culture.

Findley, 2005: $x$

Idem: 49 .

Idem. 

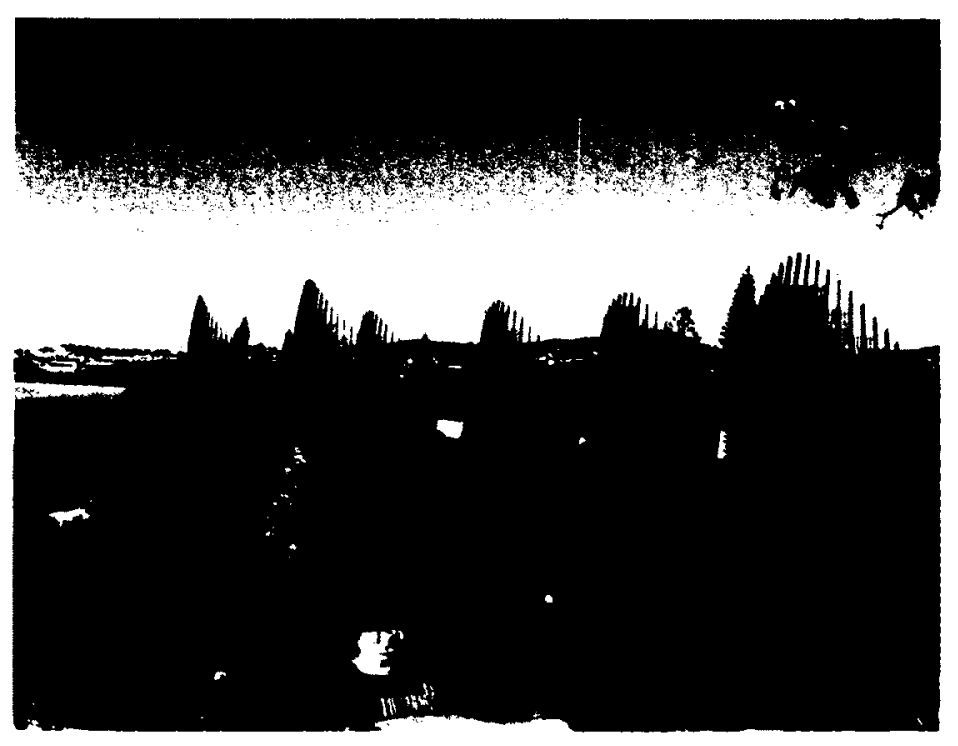

in Architecture, issue 10 (1998). Tibaou Cultural Centre [background] and traditional dwelling [foreground].

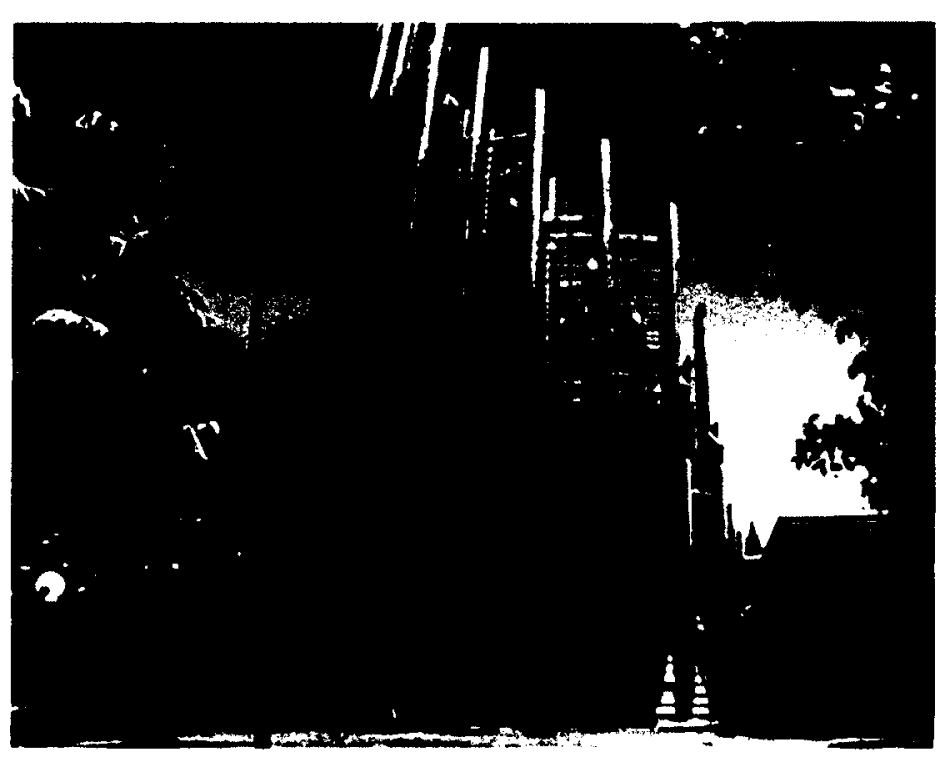

Maclellan, Nic (2012). The Tjibaou Cultural Centre in Noumea. 
In 1971 the Cultural Education Centres Program (CECP) originated from the work of the Department of Indian and Northern Affairs (DIAND) together with Secretary of State, which provides the funds for the implementation of cultural centres. ${ }^{32}$ Currently, the First Nations Confederacy of Cultural Education Centres (FNCCEC) is the national non-profit organization that represents eighty-seven First Nations Cultural Centres. The FNCCEC is directed by community members to carry the national mandate to protect, promote and revitalize First Nations languages and cultures. ${ }^{33}$ Elizabeth Biscaye, from the Northwest Territories Board of Governors, describes:

"Every region has to struggle by itself to try to further the cause, to try to further the opportunities for people. Where here with this organization (the FNCCEC), there is a national body that speaks for us. We know that if we raise concern, they will pursue it. In a lot of cases, our voices get heard at the national level because of that. I think it is very significant and very important". 34

Unfortunately, the FNCCEC's website states that the funding for the CECP was capped and frozen in 1985 by the Treasury Board, preventing the creation of additional centres and programs. ${ }^{35}$ Today, long time centre directors and cultural workers estimate that the CECP is underfunded by at least $50 \%$, while cultural awareness and its value has risen dramatically in communities across Canada. As a result, cultural centres and programs have much more to do with fewer resources than ever before. Architect Bret Cardinal - son of Douglas Cardinal who worked with his father on Asinabka National Indigenous Centre's first schemes - explains that the fact that First Nations do not get a lot of money means that they cannot afford "crazy designs;" the focus is on getting the project built at all. ${ }^{36}$ Furthermore, he explains that for First Nations the priority is the funding of homes and shelters over the development of cultural centres.

\section{.......}

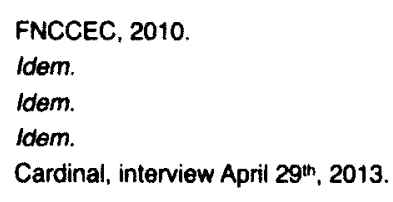


Claudette Commanda, FNCCEC's Executive Director, envisions that the Asinabka National Indigenous Centre would be managed by the First Nations Confederacy of Cultural Educational Centres; in other words, taking advantage of national funding. ${ }^{37}$ As Leanne Simpson declares: "We do not need loads of cash to develop fancy curricula and learning programs; we need to provide opportunity and support, and then get out of the way." 38 Conversely, Claudette Commanda says that some people within the government administration strongly believe that Algonquins should raise the necessary funds for the construction of such a centre. In her opinion however, this is an opportunity for the Federal Government to make reparations to Algonquins for the consequences of colonization: hundreds of years of inequity, domination, assimilation and social genocide. ${ }^{39}$

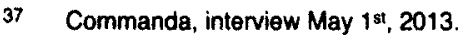

38 Simpson, 2008: 82.

39 Commanda, interview May 1s, 2013. 


\section{Part 3 :}

Nihinawizi: The Community

Engagement 


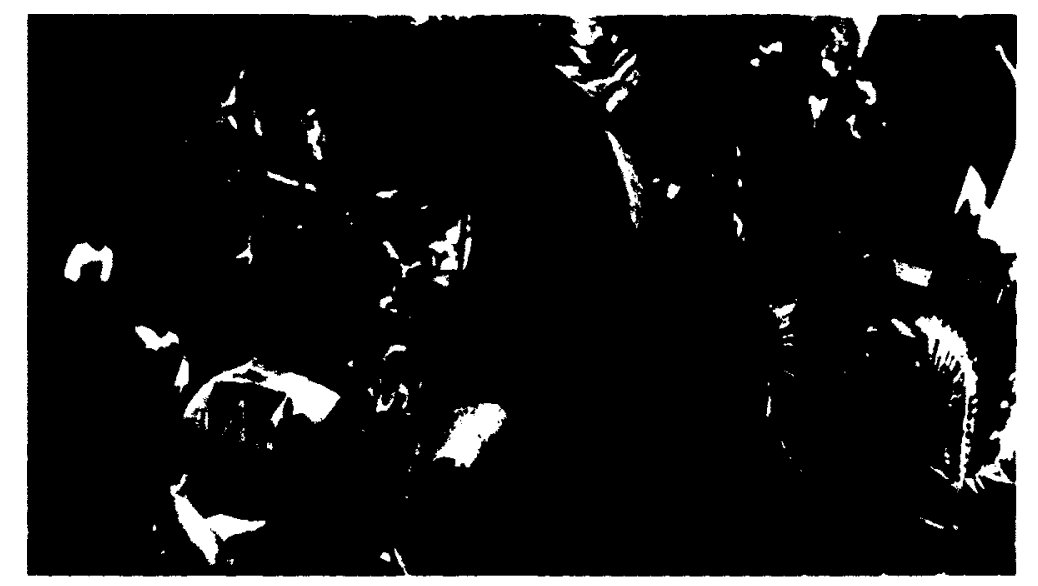

Pikwàkanagàn First Nation (2012). Algonquin Pow Wow. 
Remember that more than half of our population is under the age of 25. We can no longer ignore our young people. Remember, they are the ones who will have to take care of us and our communities when we are older.

Remember that we are responsible for the next seven generations to come. We must make good decisions for ourselves and our communities no matter how hard they are to make. We must do this so that the generations to come will not continue to suffer as many of us do today.

Lynda Gray

Author and Founder of the Adaawx Publishing (in her book First Nations 101, Vancouver: Adaawx Publishing. 2012: 269.) 
When healing victims and offenders, the healing circle also empowers the community since it participates closely in the decision-making. "It is the community working together to heal each other." 1 Aboriginal people have always ensured that everyone in the community is taken care of, always keeping in mind the best interest of the community. Leanne Simpson says: "We hold

responsibilities to our clans, communities, and our nations, and we hold these responsibilities close to our hearts. Our work is embedded in community." 2 This philosophy is in striking opposition to a more Western, individualistic and capitalist vision.

Moreover, the healing circle looks forward not only to the rehabilitation of an offender but also to the decolonization of Aboriginal communities. These two principles - individual and communal - are interwoven. Leanne Simpson explains this connectedness:

\begin{abstract}
"The belief is that by changing oneself, you can change your reality, and by committing to a process of decolonization and Indigenizing, a collective transformation can occur. Aided by beings in the spiritual realm, our political processes shift as we decolonize our traditions, our knowledge, and begin to live our traditions as a collective. As we began to act strong, healthy, independent Indigenous Nations, a new political reality emerges, and a new people emerges who are equipped with the tools and strategies in the war against our territorial losses and colonial attempts to disengage us politically." 3
\end{abstract}

Brock Pitawanakwat summarizes this connectedness: "By reconnecting with our Indigenous roots, we benefit not only as individuals, but also as nations; the individual tree grows and the whole forest grows with it." 4

$$
\text { -...... }
$$

The Asinabka National Indigenous Centre will be addressed as a community; as a community sitting and participating in a healing circle, which aims to rehabilitate the offender and ensure the victims' resurgence. In this way, the community is simultaneously a geographic concept - the

Public Safety Canada, 2012

Simpson, 2008: 17.

Idem: 75.

Pitawanakwat, 2008: 163 
physical area of the Indigenous Centre - and a 'lived experience' 5 - gatherings, workshops, celebrations, etc. - that is at the same time shared with others.

This broader healing circle will seek also the decolonization of Aboriginal people. It intends the self-governance and self-determination of Native communities, as opposed to the present oppressive legislative system. Decolonization would bring an end to Canada's imperialist relationship with Aboriginals, together with an end to the colonial imposition of foreign systems governmental, ideological, spiritual. William Commanda advocates the importance of forgiving: “I think forgiveness is a big thing. What [foreigners] did to us, we have to forgive." 6

\section{The Circle: Representation of the Community}

The circle has important and profound cultural significance for many First Nations, symbolizing the interconnectedness of all things and directing consideration of the impact on all partners when decisions are taken. The concept of the circle is synonymous with balance, openness, and a holistic approach to life. ${ }^{7}$ Since the circle is inherently non-hierarchical and inclusive, it represents respect, equality and continuity. J.R. Walker relates the importance of a circle to Aboriginals as followed:

"The sun and sky, the earth and moon are round like the shield, though the sky is deep like a bowl. Everything that breathes is round like the body of a man.

Everything that grows from the ground is round like the stem of a tree. Since the Great Spirit has caused everything to be round, mankind should look upon the circle as sacred for it is the symbol of all things in nature. For these reasons we sit in a circle in all ceremonies." 8

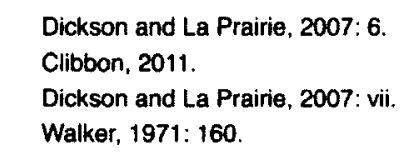


Black Elk, spiritual advisor of the Oglala Sioux, adds:

"You have noticed that everything an Indian does is in a circle, and that is because the Power of the World always works in circles, and everything tries to be round. In the old days, when we were a strong and happy people, all our power came to us from the sacred hoop of the nation and so long as the hoop was unbroken, the people flourished.

The flowering tree was the living centre of the hoop and the circle of the four quarters nourished it. The East gave peace and light, the South gave warmth, the West gave rain and the North, with its cold and mighty wind gave strength and endurance. This knowledge came to us from the outer world with our religion. Everything the Power of the World does, is done in a circle. [...] Birds make their nests in circles, for theirs is the same religion as ours". 9

Native communities are embedded in the circle; therefore, to address the National Indigenous Centre as a community means to address it as a circle, where all individuals are regarded as equal. In this way, it is more appropriate to regard the composition of the centre as a "unified body of individuals," 10 where participants are interpreted as pavilions. I believe this approach is more suitable than a single and massive building as presented by Architect Cardinal.

To address the Indigenous Centre as a circle also involves a time component, as nature progresses according to cycles and seasons. A cultural centre that promotes Indigenous

knowledge and education cannot be addressed linearly as in Western culture and tradition.

Therefore, rather than imposing a formal schedule as the traditional tendering method would do, the Indigenous Centre will progress in phases established according to economic, political and social needs and constraints. This natural progression, thus circular vision, represents the circle of life as Black Elk portrays:

"The sun comes forth and goes down again in a circle. The moon does the same and both are round. Even the seasons form a great circle in their changing and 


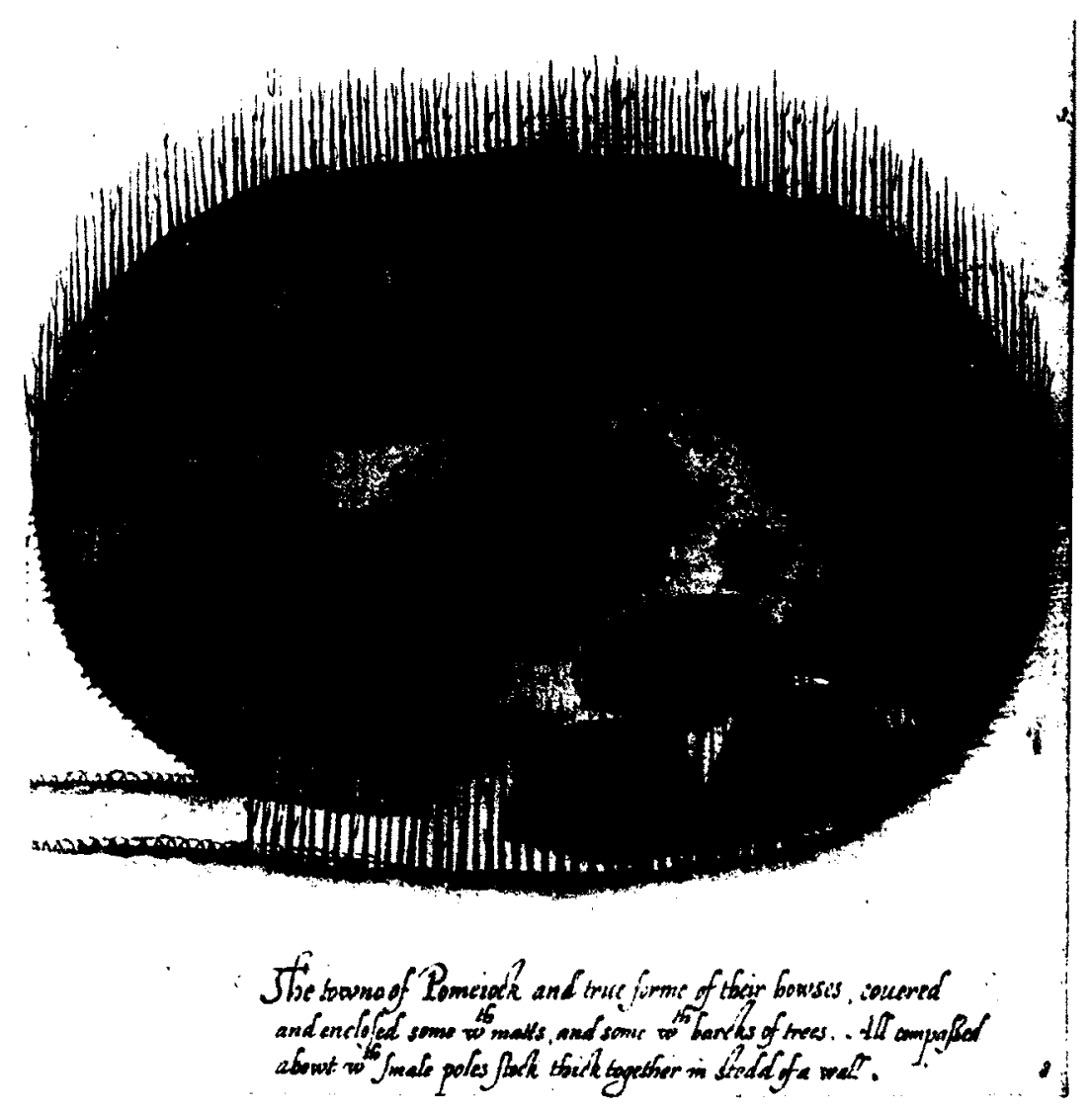

White, John (1595). Algonquin Village of Pomeiock, Gibbs Creek, North Carolina. 
always come back again to where they were. The life of man is a circle from childhood to adulthood and so it is in everything where power moves." 11

The circle of life values equality, respect, harmony and interconnectedness in the goal of maintaining personal balance. ${ }^{12}$ The medicine wheel is the native symbol, common to all Aboriginal communities, which can help to conceptualize all aspects of this balance. The four equal sections of the circle represent the four colours of human being: yellow, red, black and white; the four cardinal points: east, south, west and north; the four seasons: spring, summer, autumn and winter; the four elements: earth, fire, water and air. Mind, body, spirit and Creation are also four points of the circle. ${ }^{13}$ Since the four points are part of the same circle, everything that we do has consequences for something else. Thus I prefer to focus on the connections between the sections, and on the movement between the points rather than thinking about a punctual location. The medicine wheel's central point represents plurality, where all things come together in a circle.

$$
\text { - } \cdots \cdots
$$

In another perspective, the circle also represents the layout of the Algonquin ancestral village after sedentarization, ${ }^{14}$ as clearly represented by British artist and mapmaker of the sixteenth century John White. ${ }^{15}$ Traditionally the village was inscribed within a circular palisade that assembled many individual structures - wigwams and longhouses, Algonquin's traditional dwellings ${ }^{16}$ - arranged along the palisade leaving the centre free for multiple uses. In the proposed project, these wigwams and longhouses will be reinterpreted as individual members of the community. Specifically they will take the form of pavilions that will host gathering and exhibition spaces. meeting spaces, a conference centre, workshops, galleries and archives.

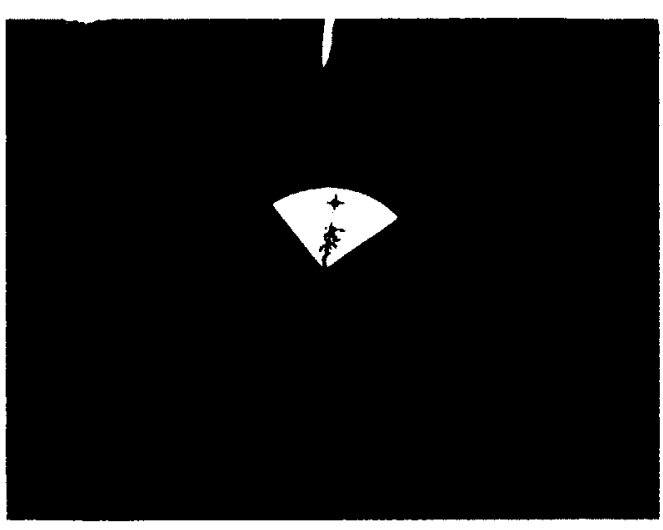

Fyeland, Sarah (February 4, 2011). The Medicine Wheel

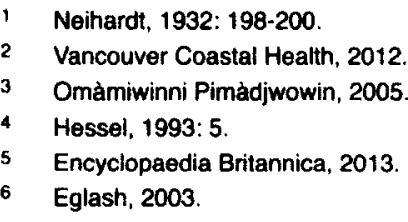




\section{Achievement:}

\section{Community Participation}

In reserve territory, vandalized buildings are common and tolerated. This phenomenon exists because the community does not care for these buildings. Architect Bret Cardinal explains that since the government funds the majority of the buildings located within the reserve, and that these are built by non-Aboriginal workers, the community does not give any importance to those structures. ${ }^{17}$ By contrast, they would care if the buildings had been built by their fathers, ancestors or community members. Community participation is key to every project related to Aboriginal communities.

According to Bret Cardinal, participation involves sustainability; in other words, we have to make sure that when a dollar is invested, it cycles within the community as many times as possible, creating employment for Aboriginals (rather than benefiting people from outside the reserve) ${ }^{18}$ thus building hope, skills and, most important of all, community. Architecture can be a mean by which Aboriginal culture can be retrieved and strengthened. ${ }^{19}$ Bret has worked with his father Douglas Cardinal and Architect Steve Rotman for the redevelopment of the Ouje-Bougoumou Cree reserve in Québec where this process has been applied and has demonstrated perseverance, participation and achievement in the community.

In the 1960s through collusion among the mining companies and the federal and provincial governments, the Oujé-Bouboumou Crees were forced to relocate their villages several times. ${ }^{20}$ Since then, the community has worked vigorously to obtain government cooperation while demonstrating their intentions to occupy and govern their traditional territory. In May 1992 negotiations concluded when Oujé-Bougoumou and the Government of Canada signed an agreement by which the government would contribute financially towards the construction of a new village. Subsequently, the community participated at every level of decision-making and direction-

Cardinal, for TEDxOttawa Novernber 11, 2011

18 Idem.

Idem.

Oujé-Bougoumou Cree Reserve, 2000

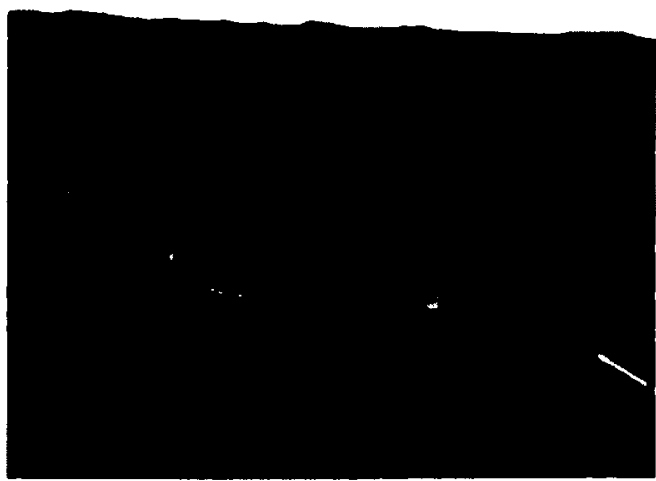

Douglas Cardinal Architect Inc. (2011). Ouje-BOugoumou Village. 
setting, from the expression of hopes, dreams and vision, to decisions on more technical matters involving the resolving of basic construction issues. ${ }^{21}$ We can read on the community website about their participation, pride and self-determination:

"If the people of Oujé-Bougoumou feel empowered by their new home, it is because they played an intimate part in its inception, creation, and construction, and because the village is a living reflection of their culture and lifestyle.

Our community is a tangible expression of our pride in our culture, and our pride in the Cree Nation. [...] The beauty of our community inspires us, it affirms our own culture and encourages us in our endeavour to improve the conditions of our communities and to struggle for the interests of the Cree Nation as a whole." 22

In 1995 the community of Oujé-Bougoumou was recognized by the Friends of the United Nations for community initiatives supportive of UN goals. During the $50^{\text {th }}$ anniversary year of the United Nations, Oujé-Bougoumou was selected by the International Panel of Advisors to receive the "We the Peoples: 50 Communities Award" in the category of Human Settlements for the effort of the Cree community in the course of constructing their new village. 23

$$
\text { ......... }
$$

The redevelopment of Oujé-Bougoumou represents one of the best examples that participation empowers the community as a whole. Furthermore, it sustains autonomy through craft and construction skills, which are less and less promoted nowadays. Following this precedent, the Asinabka National Indigenous Centre should take the opportunity to promote Algonquin arts and crafts such as wampum beadwork, canoe making, wigwam and longhouse construction, weaving and knotting techniques. The Algonquin Nation has preserved for thousands of years its skills in working with geometric arcs, as for the construction of wigwams, longhouses and lodges. It is important to note that Aboriginals have never developed their skills as masons. ${ }^{24}$ When looking at

\footnotetext{
lom.

idem.

Cardinal, interview April 29"h, 2013.
} 


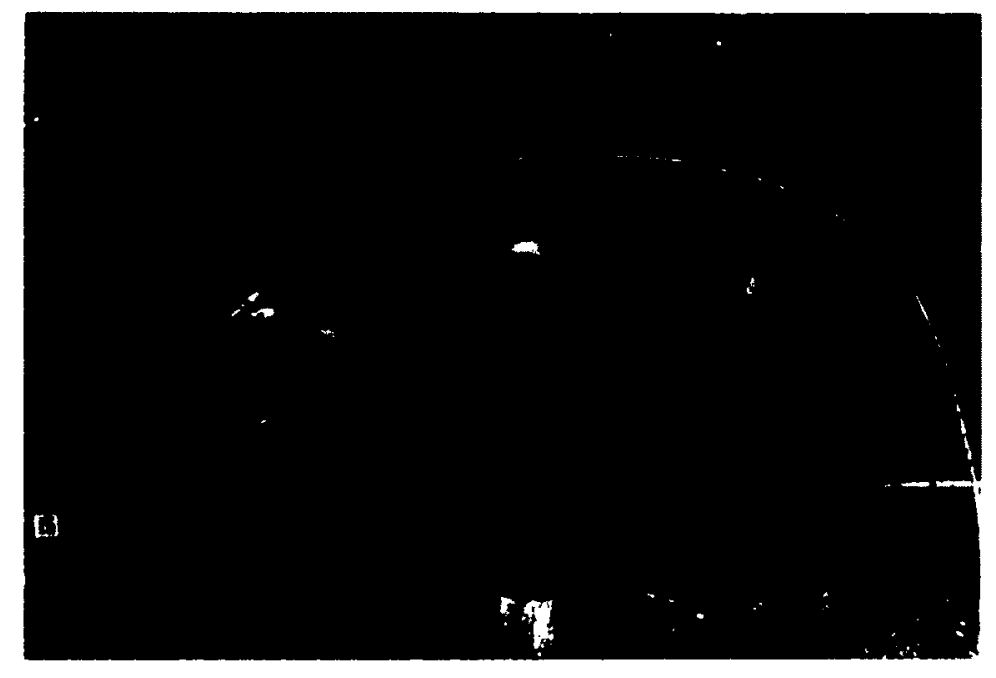

Culturally Situated Design Tools (2003). Anishinaabe Arcs

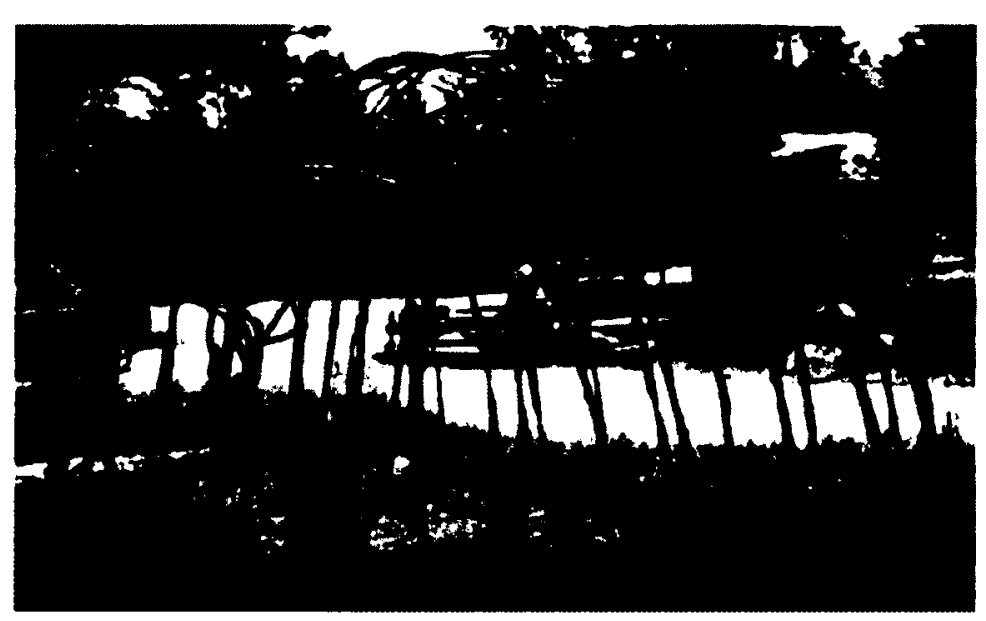

Culturally Situated Design Tools (2003). Wiigwaam. 
Douglas Cardinal proposal for the Indigenous Centre, there appear to be few possibilities for Algonquins to participate in its construction since the material range stays within the categories of masonry, concrete and/or glass work. This is a missed opportunity to empower the Algonquin Nation. In addition, Algonquin participation in the construction of the National Indigenous Centre will demonstrate to all Canadians that Aboriginals are skilful people, and that they can bring much more to the Canadian community when they are involved and invited to participate.

$$
\text { ........ }
$$

Through this counterproposal, I envision that Algonquins will work on every gathering and exhibition space, including meetings rooms, conference centre and workshops, thus placing value on everything related to Algonquin culture. Participation will valorize the cultural components since the ten Algonquin communities will have the possibility to engage directly in the construction. 


\section{Part 4:}

Asinabka National Indigenous Centre 


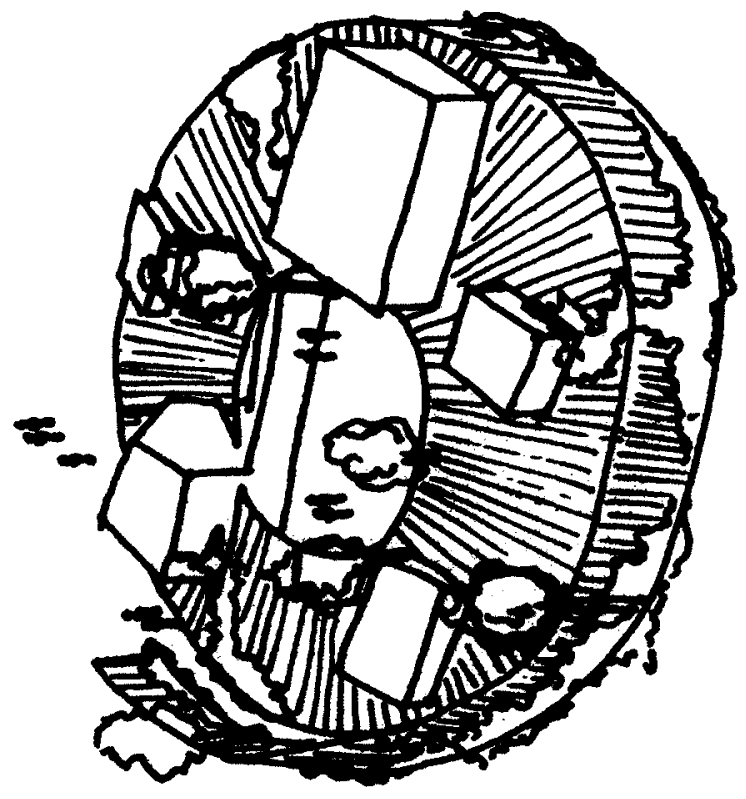


Our lives and our architecture fuse as a continual metamorphosis of Being and Becoming: a journey of destruction and creation - a joyful dance between polarities and paradoxes; a way of transformation and understanding. Much architecture rarely deals with more than style and momentary preoccupations.

However, like poetry, it can peel back the cultural layers and with familiar elements create new meanings, create spaces and relationships which set up reverberations that can through time heal, delight, calm, awaken and move the soul. It can introduce the senses to the spirit and gradually unfold the life enhancing qualities inherent in the work ... to plant a seed with a smile.

Gregory Burgess

Australian Architect

(in his essay "Towards an Ecology of Culture", in $A+U$ : Architecture and Urbanism. Tokyo, Volume 320, May 1997.) 
Douglas Cardinal's design for the Asinabka National Indigenous Centre describes a massive and monumental, $\$ 85 \mathrm{M}$ building that does not lend itself to phasing. ${ }^{1}$ It incorporates the industrial ruins inside the Indigenous Centre and uses them to house some of the Centre's program. This will require a massive preservation effort. As Bret Cardinal explains, the Carbide Mill ruins need much investment: the four-story section requires a new roof and new windows; its interior must be cleaned from pigeon faeces; and its structure needs reinforcement. ${ }^{2}$ This design strategy creates a construction dependency between the industrial ruins and the new construction that will complicate the realization of the project.

According to Claudette Commanda, such a centre is unrealistic. She advocates a more modest project and agrees that a phased approach to building is more practical and therefore more suitable for Algonquins. ${ }^{3}$ The counterproposal for the Asinabka National Indigenous Centre proposes a series of pavilions that, together with the independent participation of the ruins, act as individuals evolving within a community. Since the stabilization of the rear stone wall ruins was already accomplished in 2003 by Cintec Anchoring System to ensure public safety, building amongst these walls makes sense, whereas extending the program inside the four-story section dramatically change the focus of the construction process. ${ }^{4}$ in the counterproposal, the four-story ruin remains vacant, eventually to succumb to erosion due to weather and time.

Not only does the design strategy of constructing pavilions lend itself well to phasing, but also it is more environmentally sustainable. Passive solar methods and cross ventilation become more feasible, thus reducing the cost and dependency on mechanical equipment.

$$
\text { ........ }
$$

The elaboration of this counterproposal begins by delineating a physical circle in the ground that encompasses the industrial ruins and the pavilions as participants of the healing circle. To avoid the exclusive meaning often associated with circular forms, the circle is opened in a welcoming gesture. Douglas Cardinal explains the mission imagined by William Commanda with the same

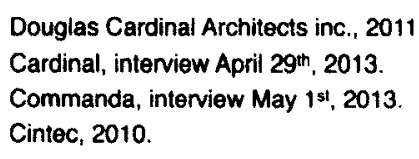



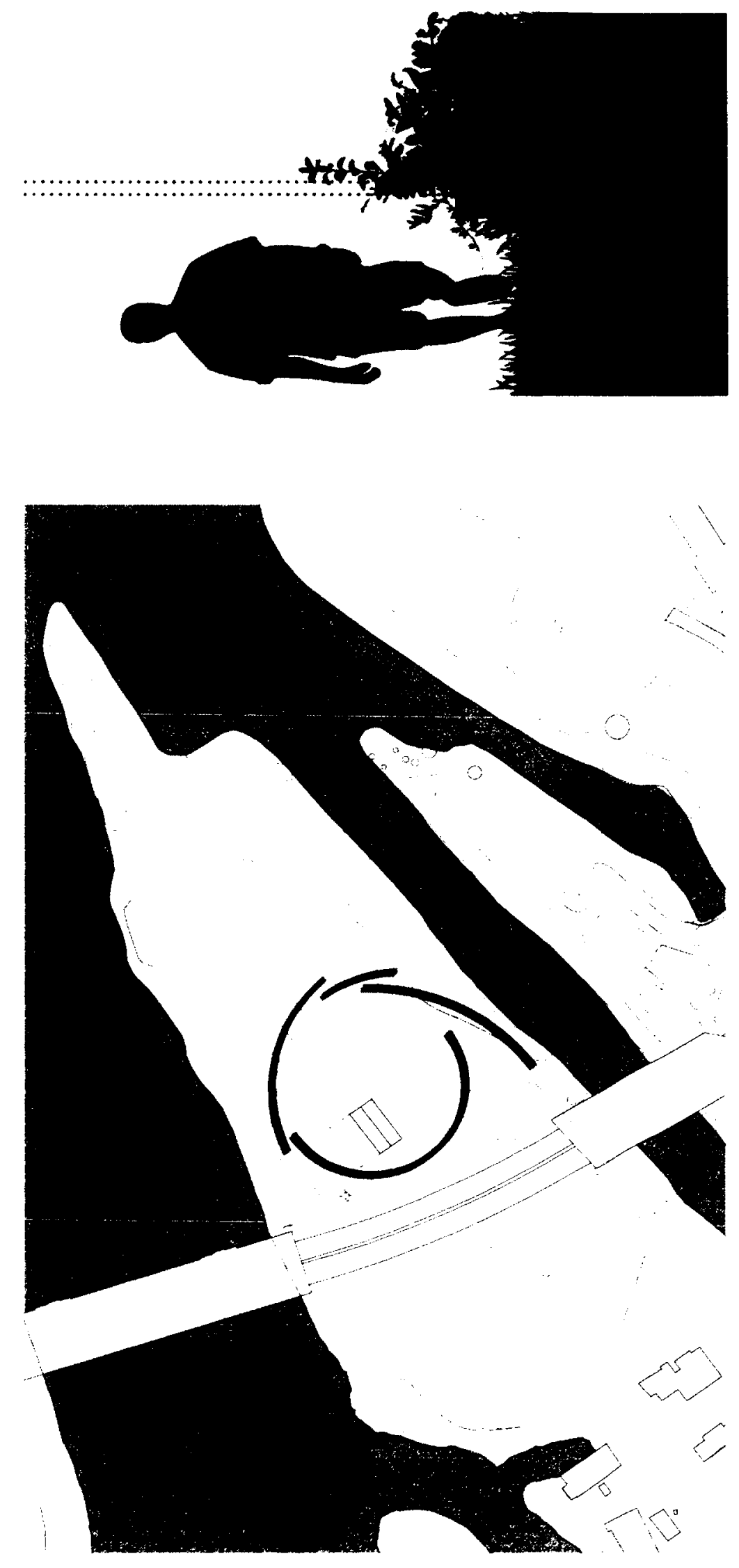
expression: "[The Algonquins] will open their circle and share their knowledge and wisdom as guardians of this land with all the people that come here from all over the world". 5

The boundary of this circle - developed as a low planter - influences the position and design of the three component layers that compose the Indigenous Centre: the wigwams, the glass boxes and the palisade. Each layer possesses a specific character that is in keeping with its relation to Algonquin culture.

\section{$\{$ Character $\}$}

: one of the attributes or features that make up and distinguish an individual.

- Merriam-Webster Dictionary

\section{The Wigwams}

For Algonquins, it is important to respect the ground since the ground bears all creations and living beings: water, rocks, trees, plants, animal and humanity. ${ }^{6}$ The relationship of the Algonquins to the ground can be compared to a tree that requires healthy roots to survive. The earth provides Algonquins with protection, food and healing. Prior to road construction and the development of cities, the ground represented an unbroken fabric; it was a single continuous landscape.

Recognizing this fundamental element in First Nations culture, the ground level of the Indigenous Centre, the first layer, is envisioned as a landscape with ramps and slopes, rather than stairs and elevators, negotiating changes in elevation. The ground is interrupted only by "wigwams", the traditional Algonquin dwellings. In the new Centre, the continuous surface of the ground level along with the space provided by the wigwams host activities that are part of

Algonquin ancestral culture and traditions, specifically activities related to gathering, eating, crafting, sharing and celebrating.

$$
\text { . . . . }
$$

Ten contemporary wigwams are scattered within the circular boundary creating a central courtyard as in the Algonquin ancestral village illustrated by John White. The ten structures represent the ten federally recognized Algonquin communities identified by Claudette Commanda, symbolizing

\footnotetext{
Circle of All Nations, 2002.

Idem.
} 

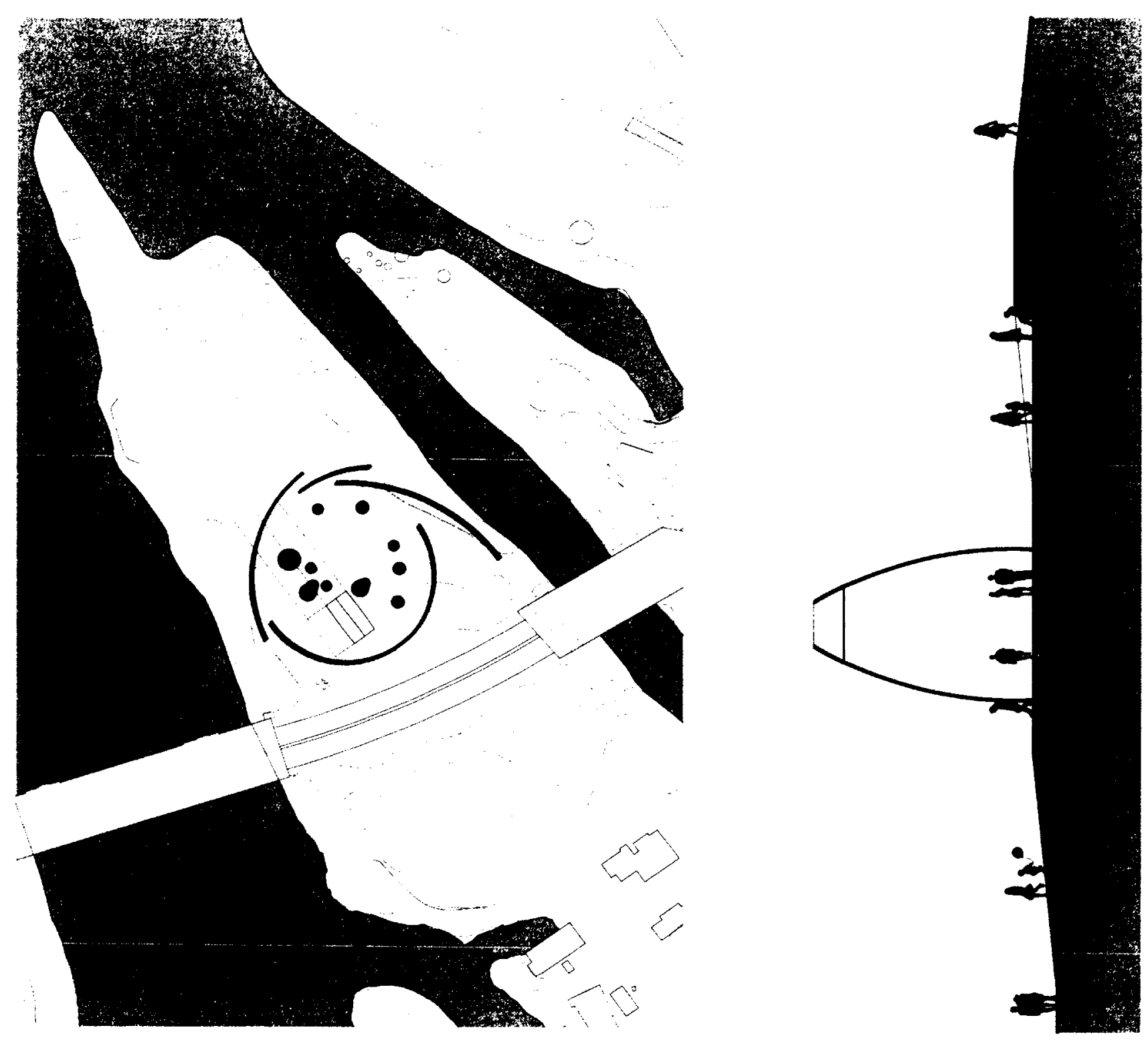
the Algonquins as a nation. 7 The "wigwams" share an architectural language but to maintain the identity of each community ${ }^{8}$ and to accentuate the effect of a gathering of individuals, each pavilion has a unique character that is identified through different and specific ornamentation.

The contemporary wigwams are constructed of traditional natural materials. Wood is exposed and celebrated as a living material. Traditionally, wigwams were built using curved saplings covered with birch bark. ${ }^{9}$ Their contemporary version presents a woven wooden structure, and modular planar surfaces: these are simple techniques that will allow the Algonquins to actively participate in the construction of the Indigenous Centre.

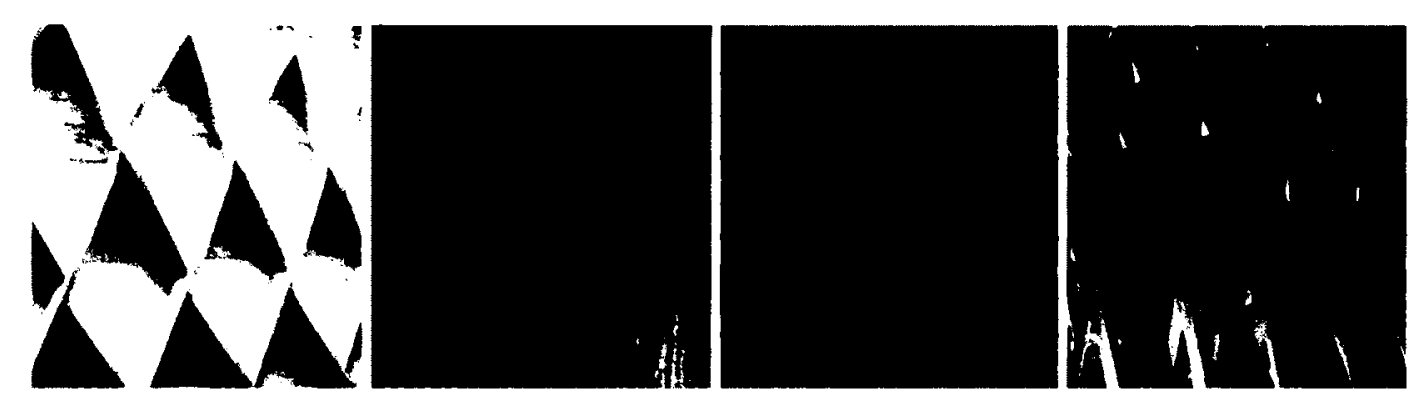

7 Commanda, interview May $1^{\text {st }}, 2013$.

The representation of the Algonquin Nation as the assemblage of the ten recognized communities is appealing to

Claudette Commanda, as well as the transposition of sell-determination and self-governance values.

8 Gray, 2012: 30.

9 Culturally Situated Design Tools, 2003 



\section{Glass Boxes}

To provide weather protection, five glass boxes cover the majority of the wigwams and their surrounding areas. These boxes form larger pavilions that include the totality of the program: workshop, restaurant, media centre, administration, and conference centre. Rather than presenting organic forms and traditional materials, the glass boxes are designed following a contemporary language that is practical, economical, and visually recedes in favour of the cultural components, the wigwams. While rectilinear forms are alien to traditional Aboriginal culture (known for its curvilinear tepees, igloos, sweat lodges and wigwams), Aboriginals have lived in rectilinear structures for the last two hundreds years. Bret Cardinal states: "[Rectilinearity] is our culture,

Aboriginal and non-Aboriginal, since we have changed and adapted." 10 In other words, there is no need to reject rectilinear construction completely in an Aboriginal construction that is taking place in 2013. Its use must simply be thoughtful and appropriate to the intended function.

Similarly, glass is an alien material to traditional Aboriginal construction, however an argument can also be made for its use in contemporary projects. According to Cardinal,

transparency can express healing since both have a lot in common. "Criminologist Mylène Jacoud explains that a healing process often involves the uncovering of issues that are hidden behind dysfunctional behaviour. ${ }^{12}$ In the case of the Indigenous Centre, the metaphoric language of the glass box reflects a desire to bring transparency to the healing circle.

$$
\text { -....... }
$$

Since the glass boxes are the metaphor of participants gathered into a healing circle, the entrances of the pavilions are located around the courtyard periphery. The services, grouped into a single volume, are located at the rear of each box. Having all the entrances facing the courtyard will allow the visitors to orient and direct themselves easily without the need for an information desk or map of the complex.
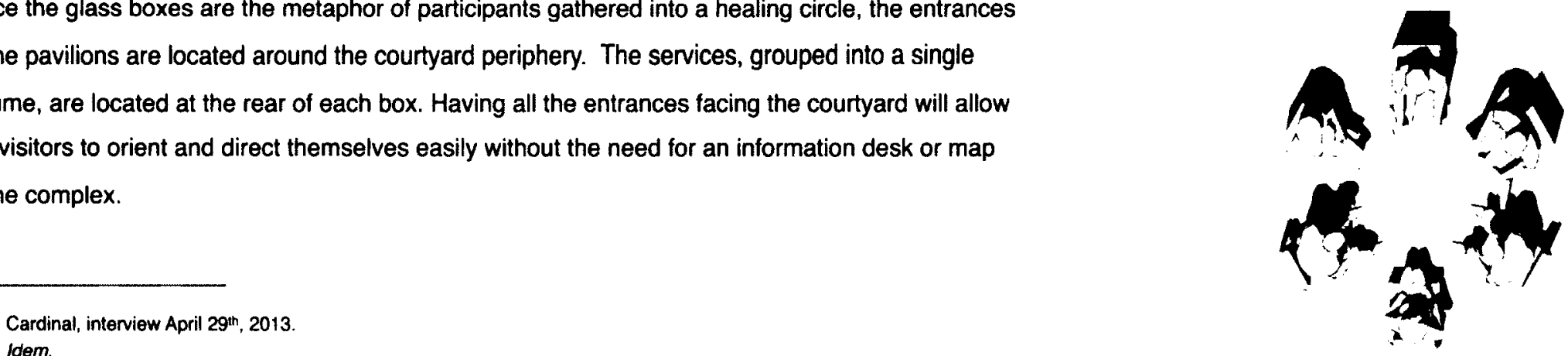

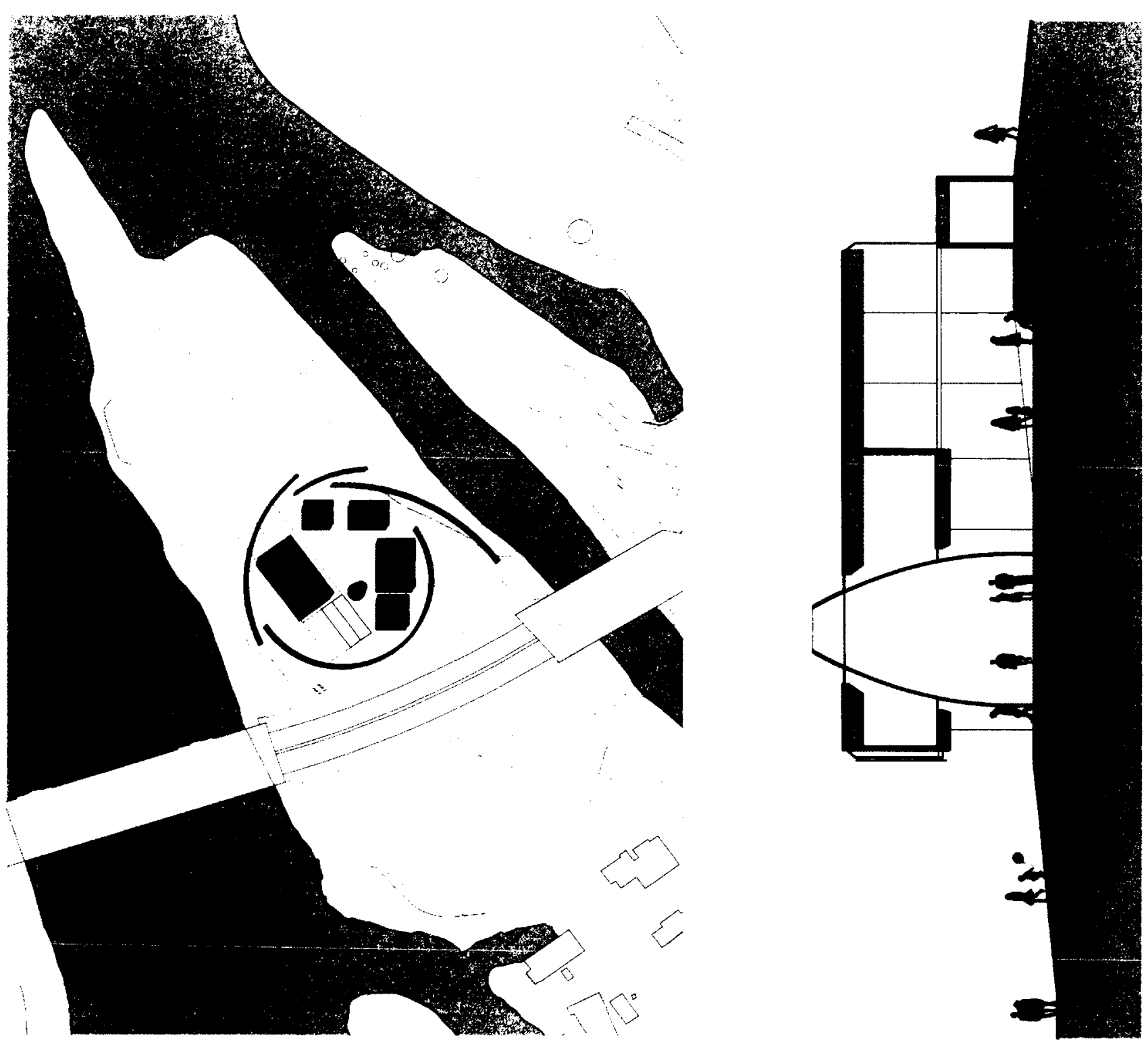
The structure of the glass boxes also provides support in some cases for a second floor where the more Western program is located: archives and offices, which are not traditionally part of the Aboriginal culture. These upper level spaces are enclosed and independent from the spaces they overlook. Accessibility by ramp reduces dependency on mechanical equipment.

Finally, the lower glass panels of each box can be raised vertically so that when open, the sense of a continuous landscape throughout the project is preserved. Thus the ground floor interior spaces are a continuation of the out door space, while the second floor spaces remain independent and enclosed.

$$
\text { ...... }
$$

The disposition of the program within the circular boundary is not aleatory; it is based upon the native symbol of the medicine wheel. The attitudes, states and qualities of the medicine wheel influence the location of the program. Thus the workshop (1) is located east, the restaurant (2) southeast, the media centre (3) southwest, the administration (4) west, and the conference (5) centre north along with the Carbide Mill ruins. 

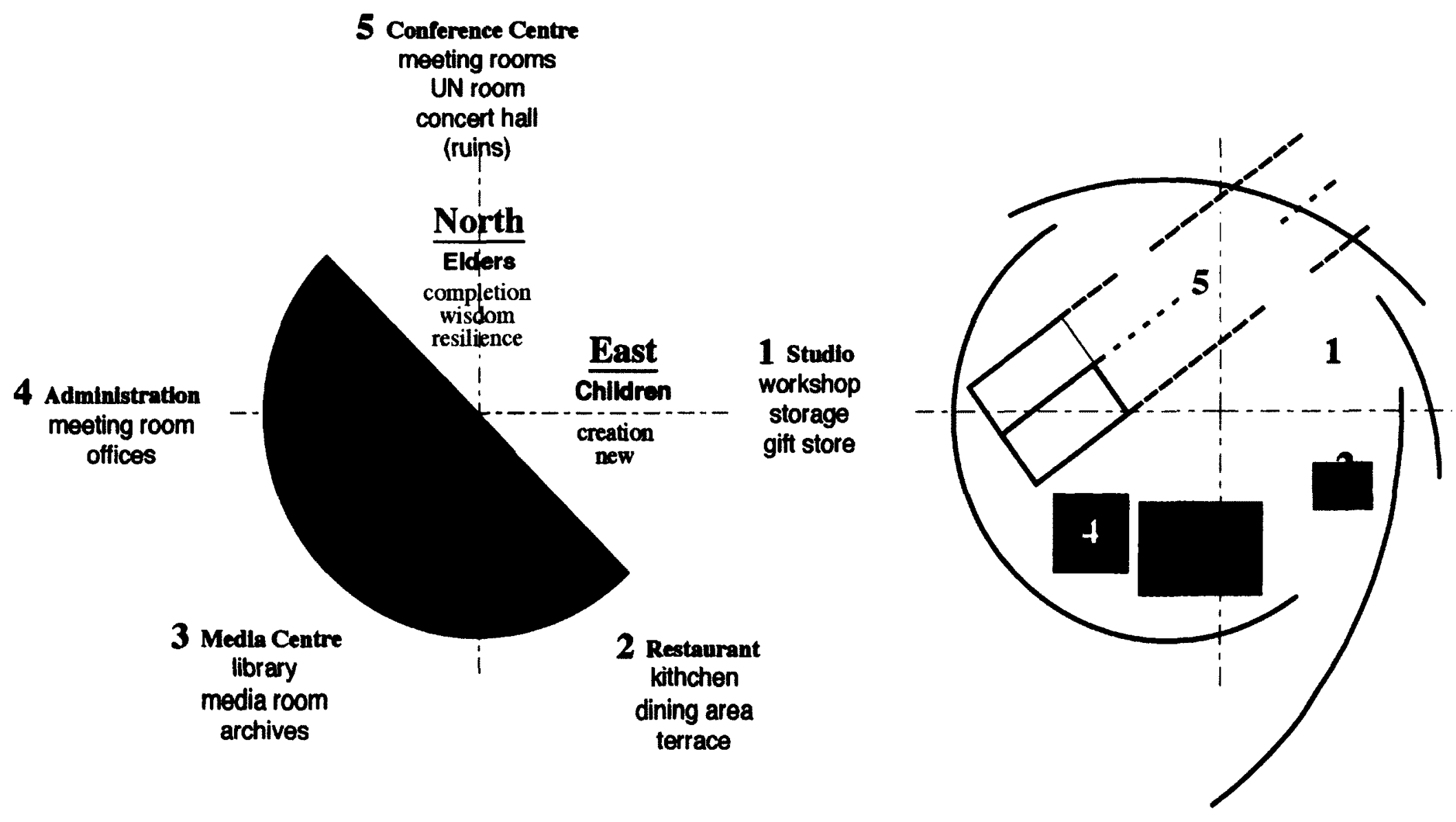


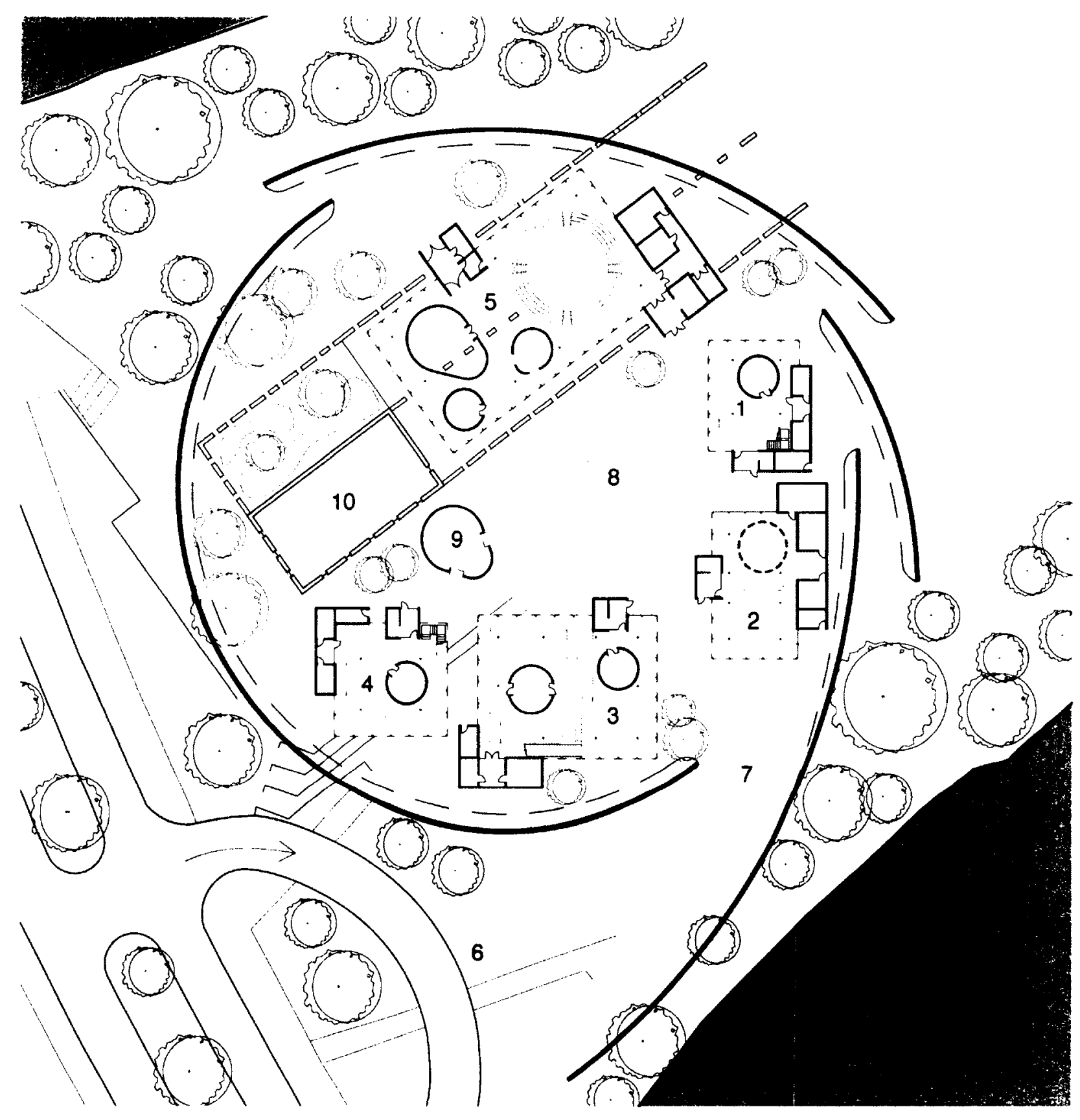

1. Workshop

2. Restaurant

3. Media Centre

4. Administration

5. Conference Centre

6. Landing Area

7. Main Entrance

Central Courtyaro

Multipurpose Space

Unoccupied Ruins 


\section{Pimikì: Atelier: Workshop}

The gitt store and workshops share the Pimiki Pavilion - which means "craft work" in Algonquin. ${ }^{13}$ Both advocate Algonquin arts and crafts. The workshop participants have the opportunity to exhibit their pieces in the circulation spaces of other pavilions. They can also choose to share and give away their pieces from display units at the entrance of this pavilion.

1. Entrance and Cloakroom

2. Gift Store

3. Mechanical/Electrical Room

7. Workshop

5. Shared Sink

8. Storage

6. Meeting Room
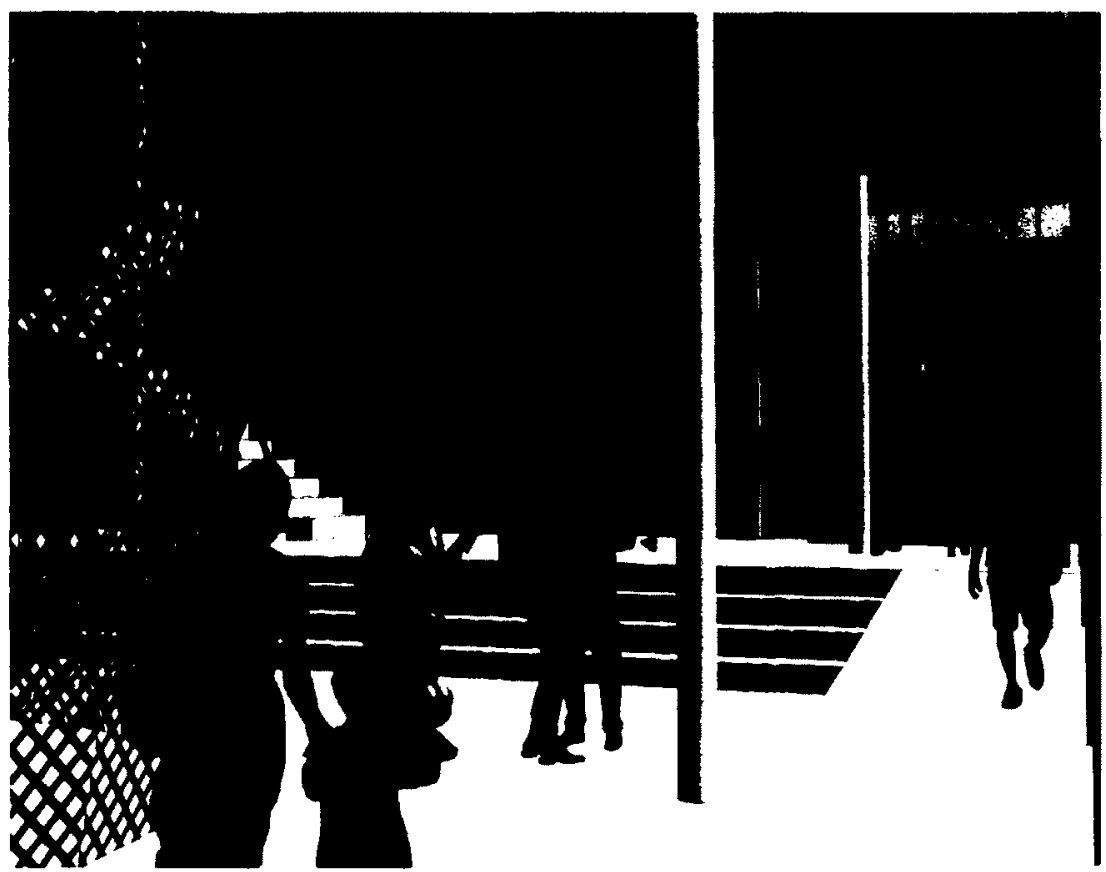

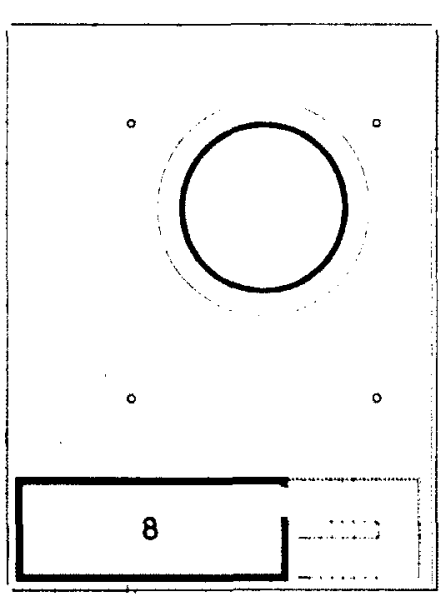

(1)

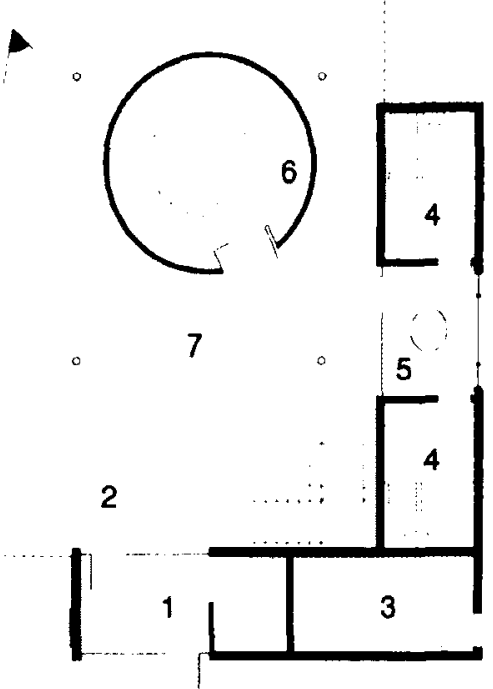

13 Omàmiwinni Pimàdjowin, 2005. 
Wisnin: Restaurant

The Wisnin Pavilion - which means "to eat" in Algonquin 14 - is not organized as a conventional restaurant where the kitchen and the dining areas are

divided. Here the kitchen overlooks the dining area. Customers circulate and serve themselves.
1. Entrance and Cloakroom
2. Dining Area
4. WC
7. Kitchen
3. Mechanical/Electrical Room
5. Shared Sink
8. Storage
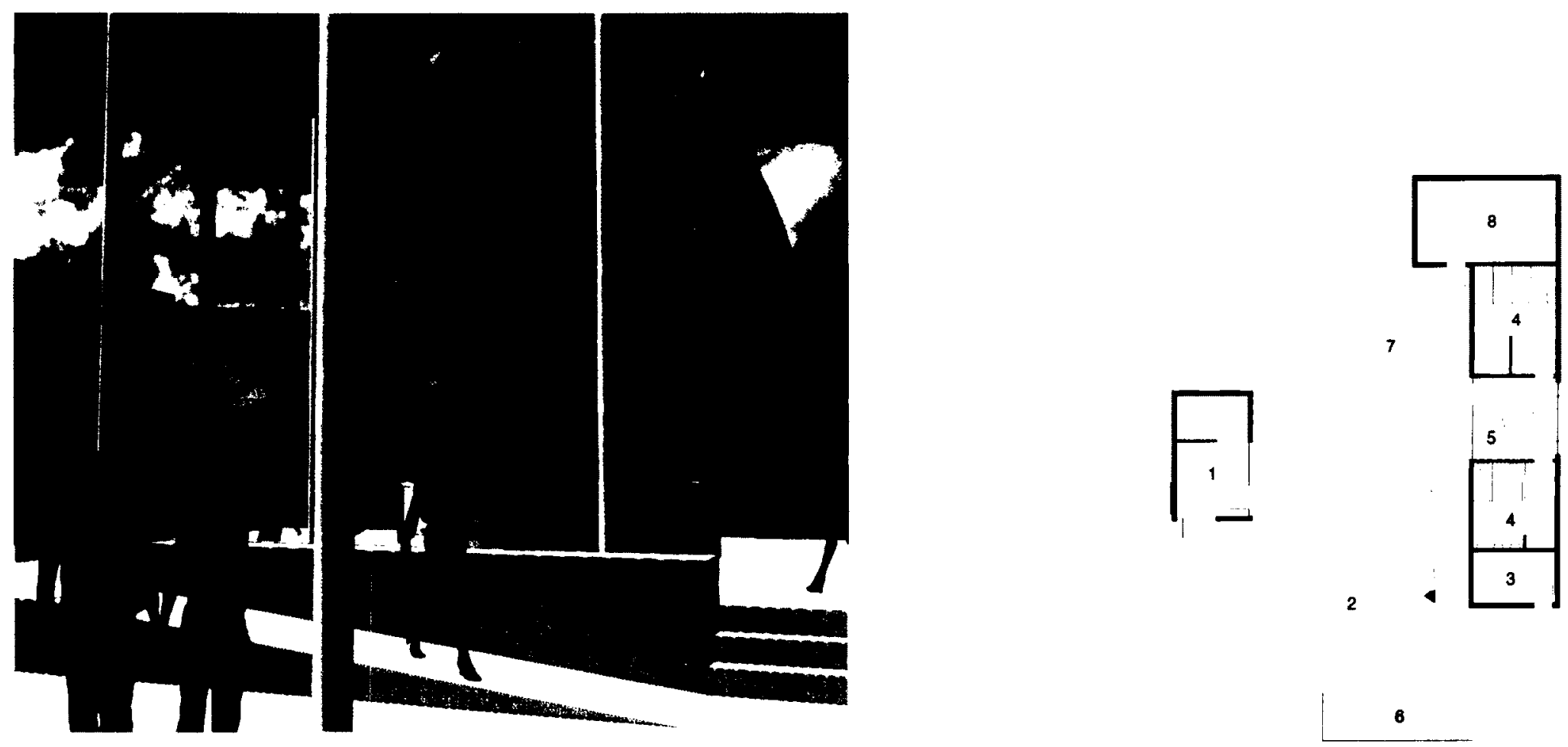

14 Idem. 
Kikinàmàgozi: Médiathèque: Media Centre

Conventionally, this Kikinàmàgozi Pavilion - which means "to learn" in Algonquin ${ }^{15}$ - would be assigned to the library. However, the concept of library is alien to Algonquins whose stories are passed down through an oral tradition. The few documents that exist, such as treaties, are enclosed and exposed in glass cabinets in the second floor archives area. With contemporary Algonquin youth more interested in new media such as photography and filmmaking, gathering spaces for discussion and creation prevail over a more traditional library layout of aligned tables and chairs. ${ }^{16}$

1. Entrance and Cloakroom

2. Exhibition Hallway

4. WC

3. Mechanical/Electrical Room

5. Shared Sink

6. Meeting Room

7. Multipurpose Area

8. Artifact Glass Cabinets

9. Searching Room

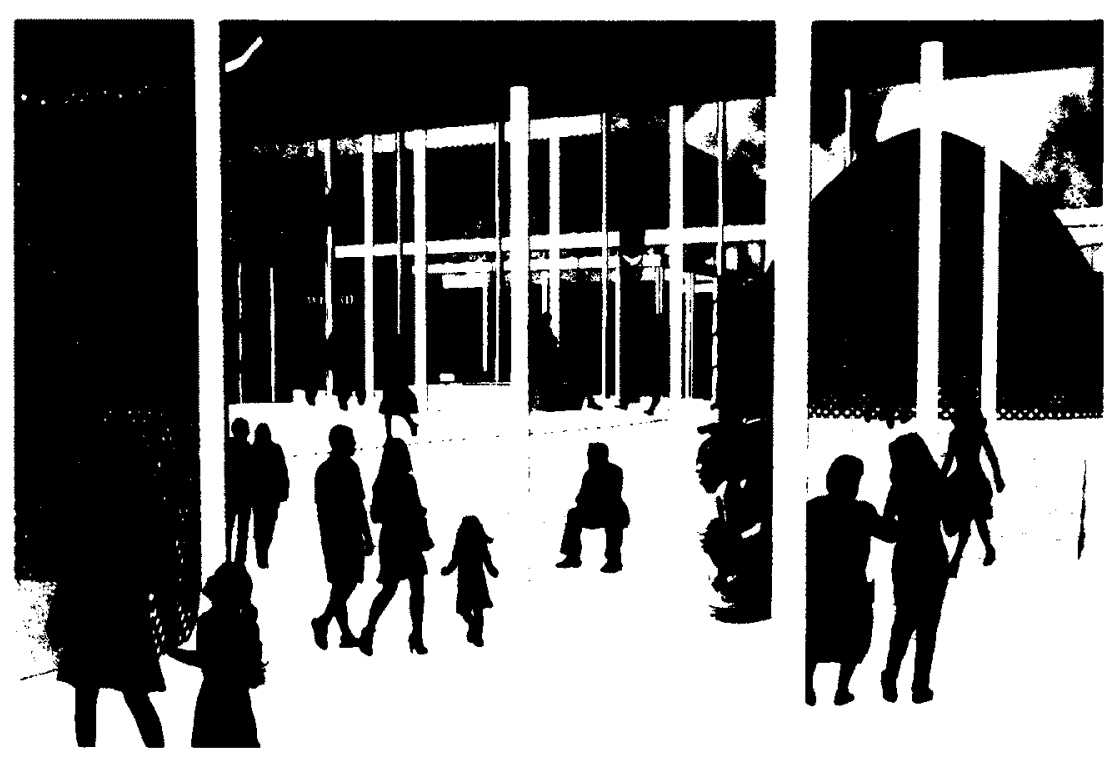

15 ldem.

16 The Asinabka Indigenous Film and Media Arts Festival demonstrates this. (CBC, 2012)
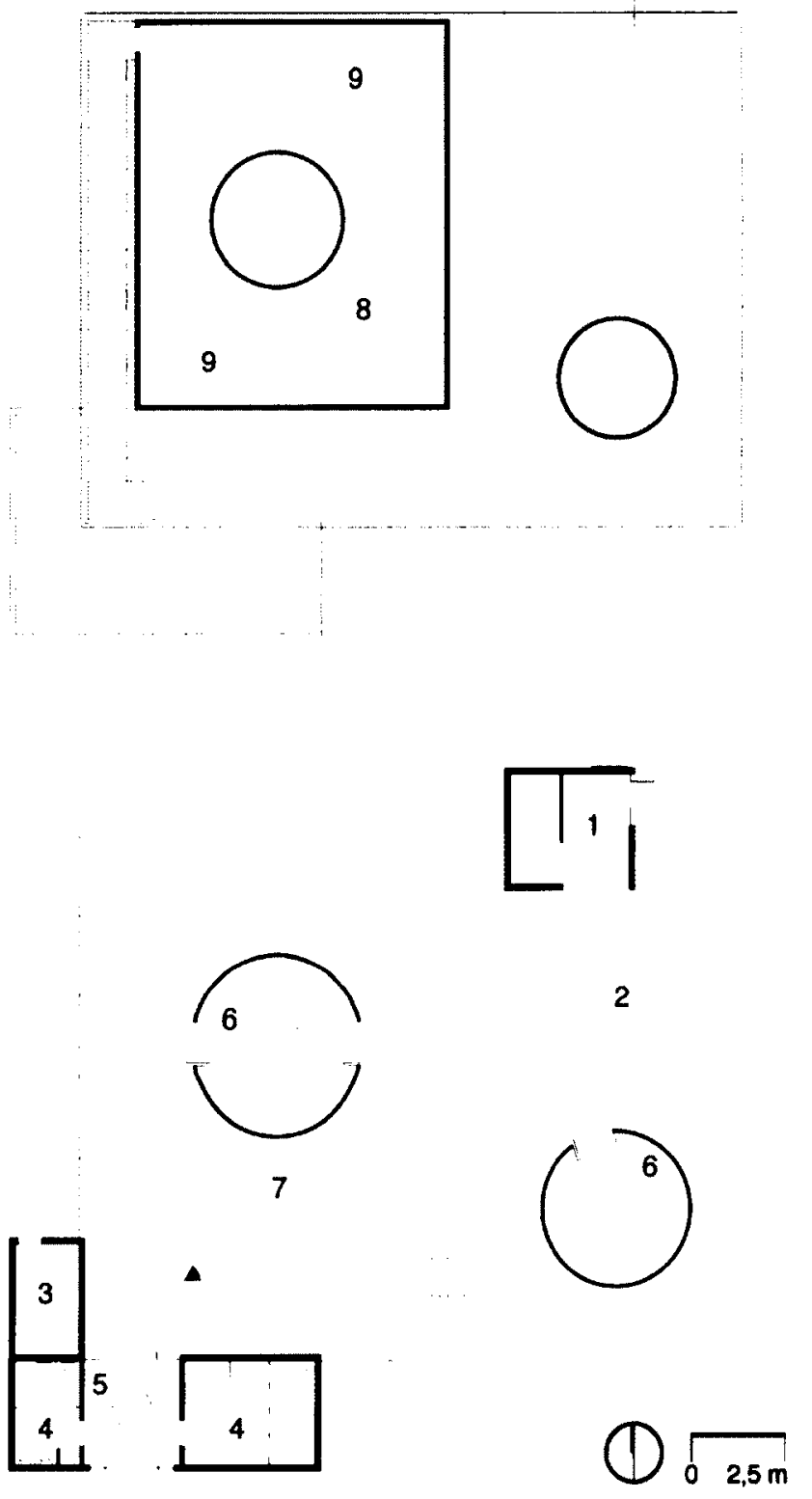


\section{Asibòdòn: Administration}

The Asibòdon Pavilion - which means "to file" in Algonquin 17 - provides offices for administrative staff. Its less public mission explains the decision to partially hide the pavilion from the courtyard panorama. Again, administration is not traditional to Algonquin; therefore, all the gathering activities such as meeting and eating take place on the first floor, while the formal administration occupies the upper level.

1. Entrance and Cloakroom

2. Exhibition Hallway

3. Mechanical/Electrical Room
4. WC

5. Shared Sink

6. Meeting Room
7. Multipurpose Area

8. Terrace

9. Offices
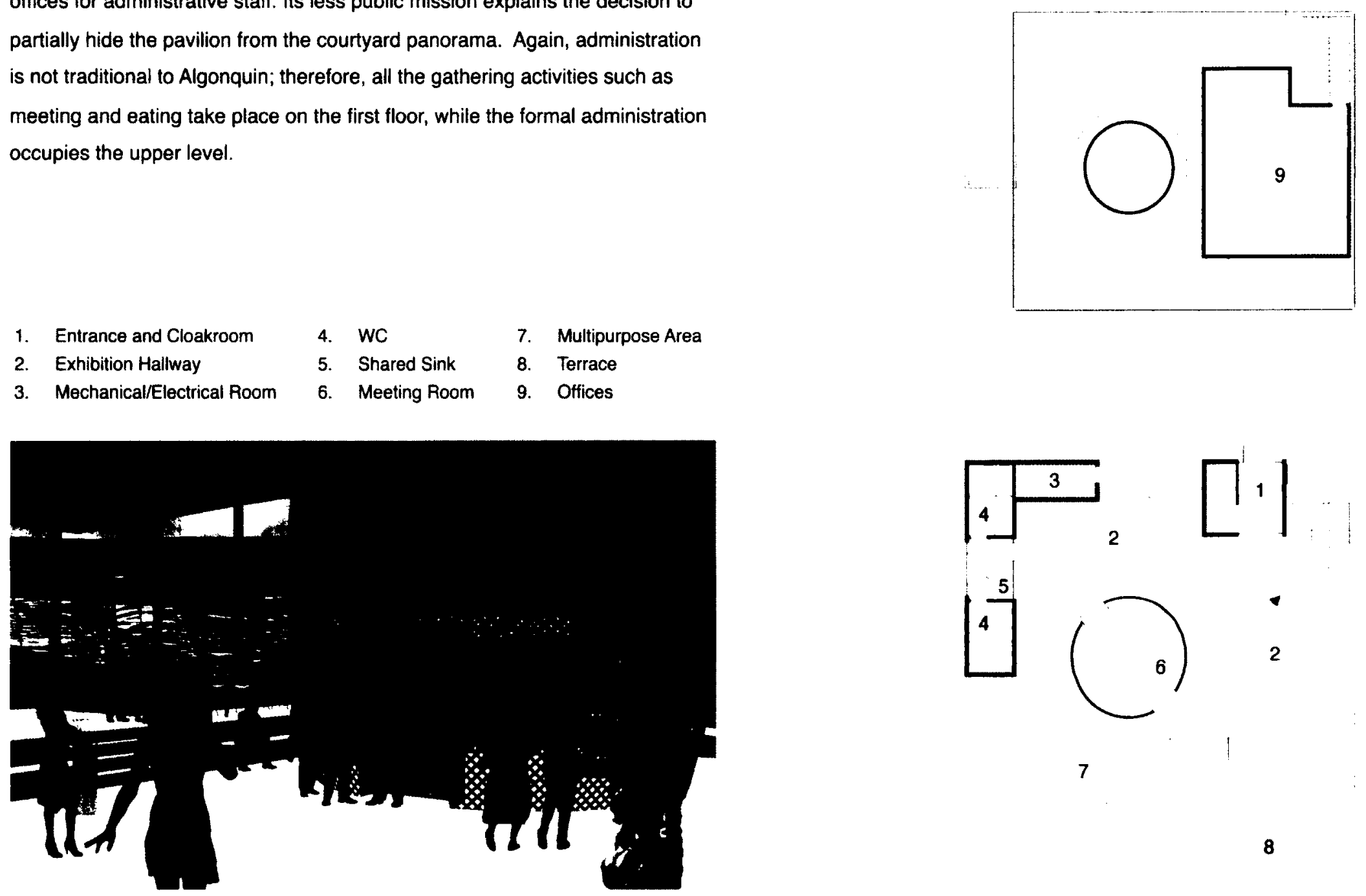


\section{Nibwàkàwin: Centre de Conférence: Conference Centre}

The Nibwàkàwin Pavilion - which means "wisdom" in Algonquin ${ }^{18}$ - gathers people in order that they can share their knowledge, experiences and creations This pavilion plays the role of both conference centre and concert hall. The multipurpose area is designed as a depression in the ground that can accommodate up to 300 people. The circulation spaces double as exhibition and gallery spaces, allowing Algonquin arts and crafts to exist as living objects rather than as static pieces as found in most Western museums. The

Nibwàkàwin Pavilion aims to celebrate Aboriginal culture in all possible forms.

1. Entrance and Cloakroom

2. Exhibition Hallway

4. WC

5. Shared Sink

3. Mechanical/Electrical Room

6. Meeting Room

7. UN Meeting Room

8. Kitchenette

9. Unloading Deck

10. Multipurpose Area

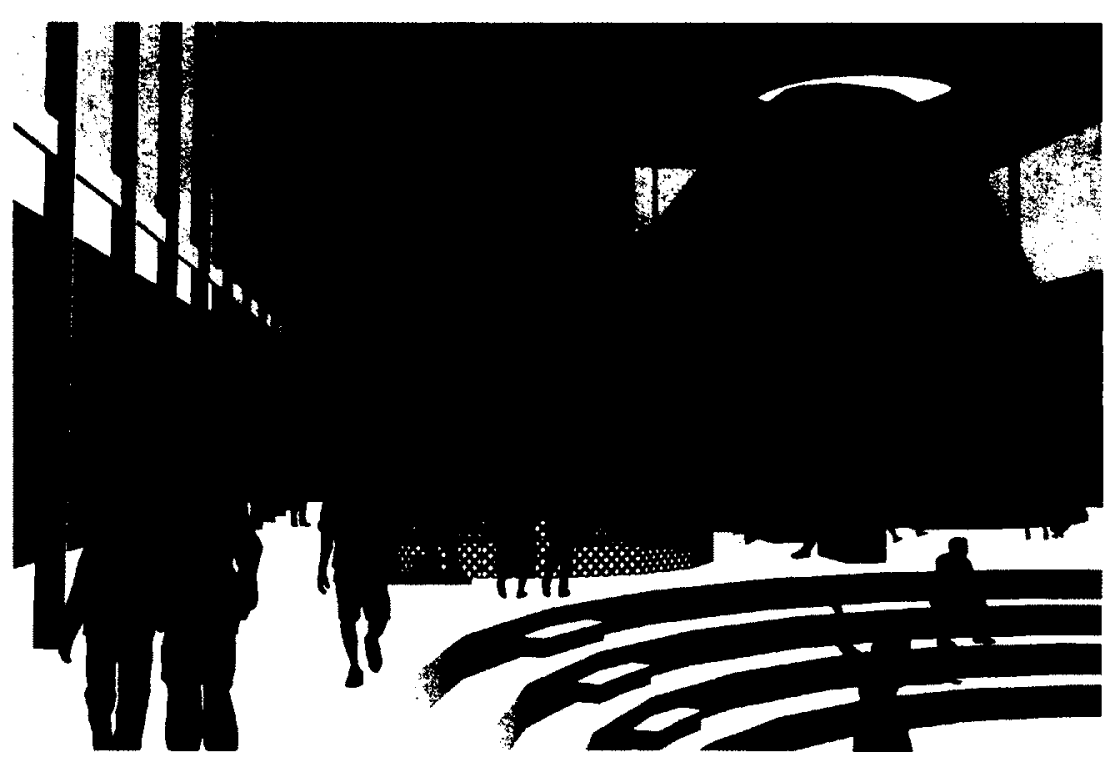

18 Idem.

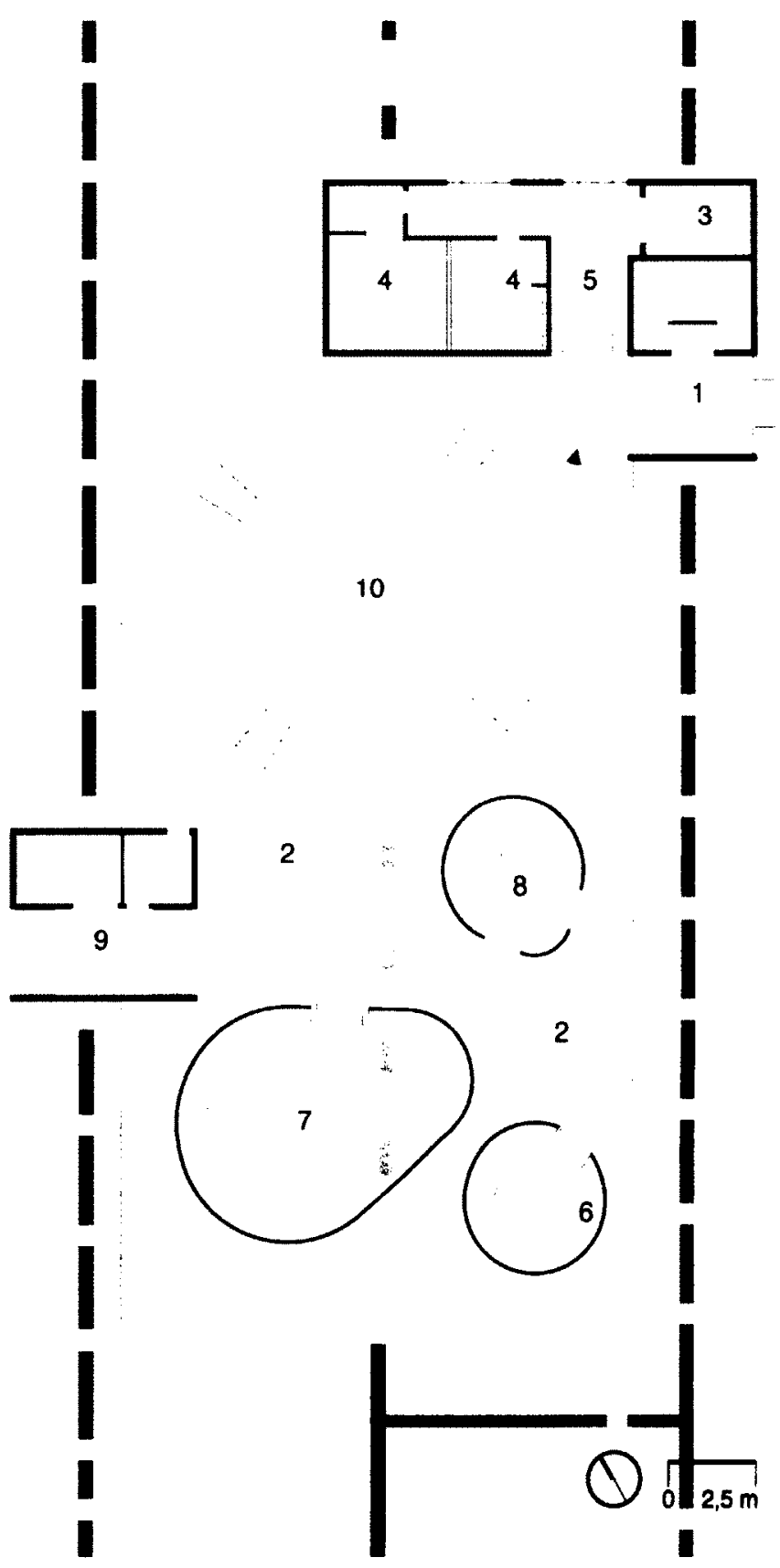




\section{Palisade}

The final component of the design of the Asinabka National Indigenous Centre consists of a vertical and permeable structure that surrounds and overhangs the complex: the palisade. It leaves the interstitial spaces between the boxes open to the air while, together with the remaining stone walls, providing shade to the interior spaces.

In Western architecture, the tendency is to have all activities take place indoors, isolated from the external environment. This philosophy is completely alien to Algonquin culture.

Traditionally people were inside wigwams and longhouses only when the weather was cold, and to sleep, otherwise they were outside. ${ }^{19}$ However, the location of the project, in the middle of the Ottawa River, makes it vulnerable to the blowing northeast wind and the strong summer sun. Traditionally, the main purpose of the palisade was to defend the village against invaders and enemies. In the case of the Indigenous Centre, the palisade protects the complex from the harsh Canadian climate while allowing passive solar heating and cross ventilation. These passive techniques reduce substantially the dependency on mechanical equipment.

$$
\text { - . . . - }
$$

The palisade consists of saplings - the traditional structure of wigwams - woven to create a latticework on which to grow climbing plants. The greenery blurs the boundaries between the palisade, the ground, and the stone walls of the Carbide Mill ruins. In keeping with the Algonquins' desire to bring Asinabka back to its original state, the vegetal screen is designed to reduce the visual impact of the Indigenous Centre. Furthermore, the woven structure highlights Algonquin culture and craft. Inspired by Algonquin traditions, it enables the Algonquin community to participate in its construction, and demonstrate its skills.

19 Culturally Situated Design Tools, 2003 

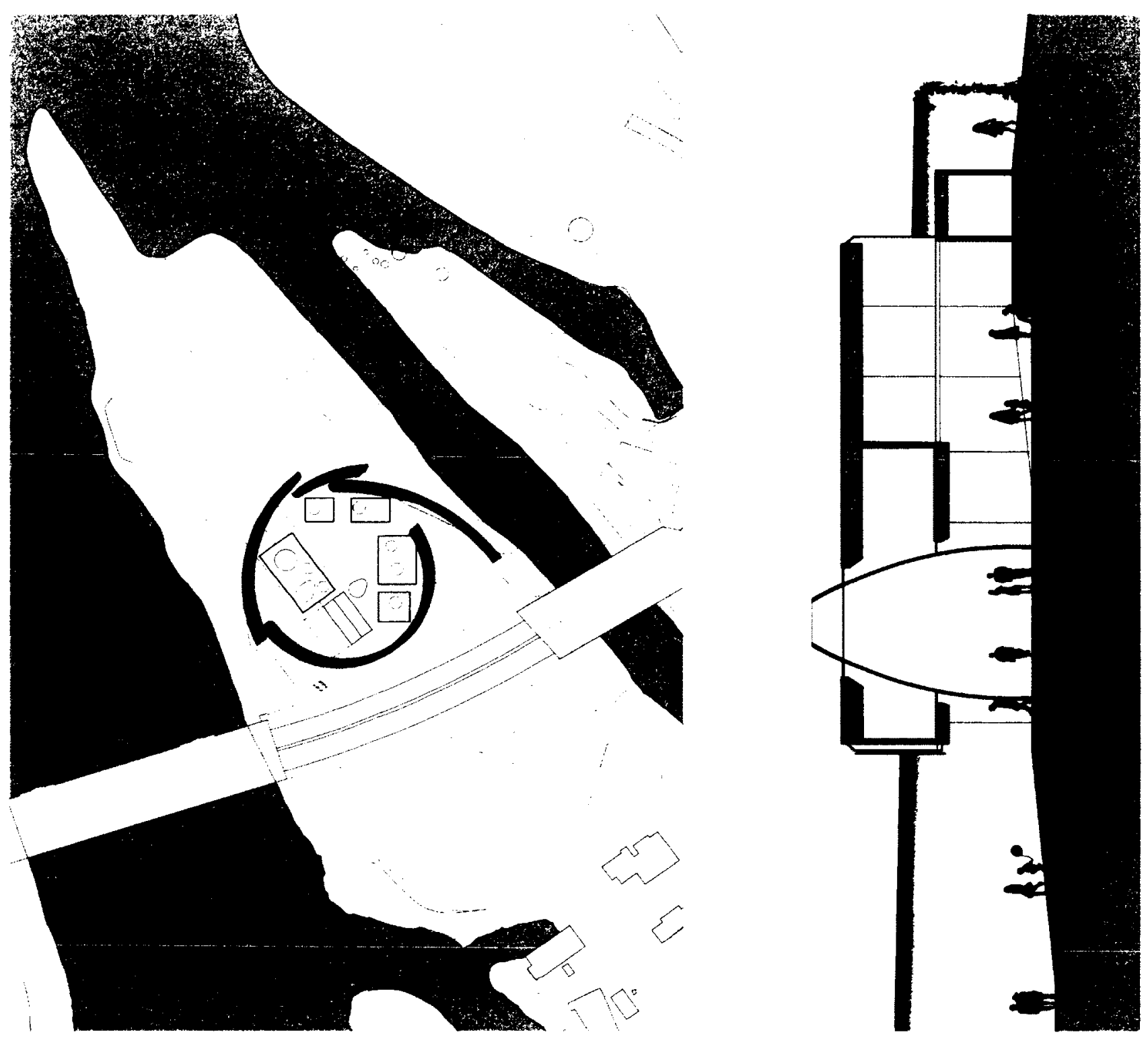

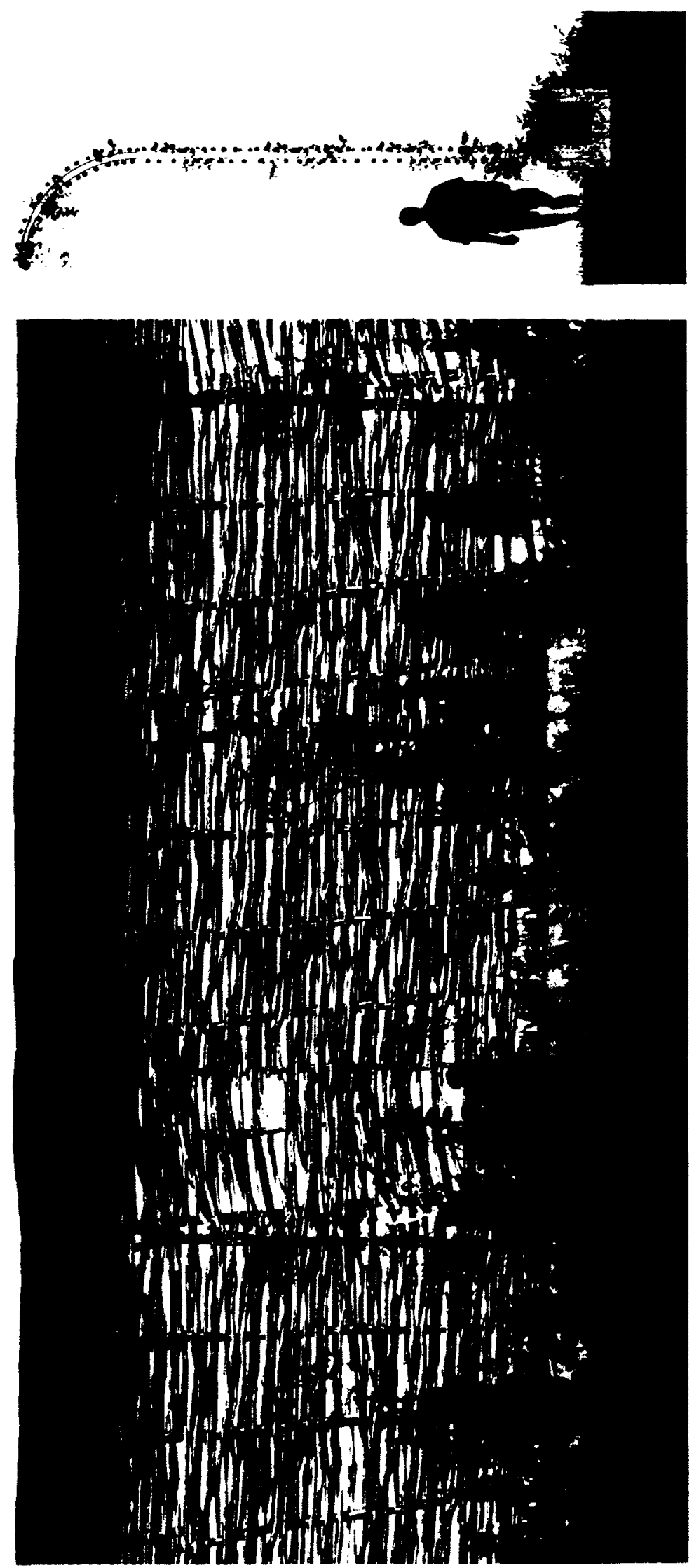


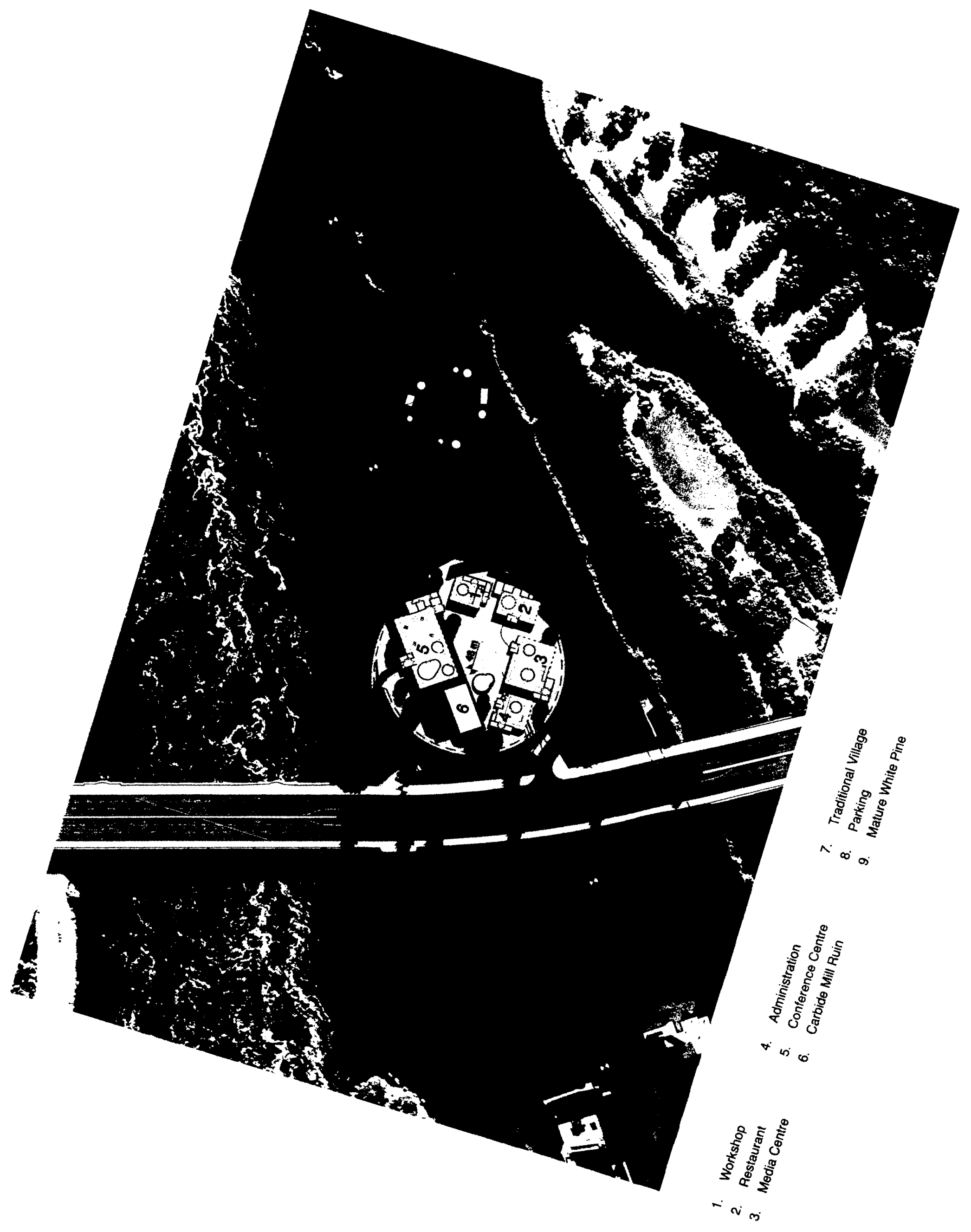




\section{Asinabka National Indigenous Centre}

Together, the three component layers (wigwams, glass boxes and palisade) create the Asinabka National Indigenous Centre located just east of the Portage Bridge on Victoria Island. Further to the east, on the point of the island facing Parliament Hill, a new mature white pine is planted. The planting of this mature tree - which can grow up to fifty meters and is one of the tallest tree of the Laurentian mixed forest 20 - proudly marks the presence of the Algonquins in the National Capital Region and constitutes an appropriate vehicle by which to establish a dialogue with the Parliament Buildings and Peace Tower. The existing Aboriginal Experiences structures are preserved and disengaged from its palisade as part of the larger Aboriginal landscape.

$$
\text { - . . . . }
$$

On the west side of Portage Bridge, a partially underground parking area provides space for more than 250 vehicles. The design accepts the reality of the car, but by partially hiding it, weakens its dominant role. From the Portage Bridge, the landscape will appear unbroken.

According to the same line of thought, the Portage Bridge is modified to facilitate pedestrian crossing and announce a change of cultural priorities on the island. The roadway is reduced from six to four lanes to accommodate a wide median with trees and wide tree planted sidewalks on either side. This will also reduce traffic speed. Someone crossing from one province to the other will be conscious of the fact that they have entered a territory where different cultural values are celebrated.
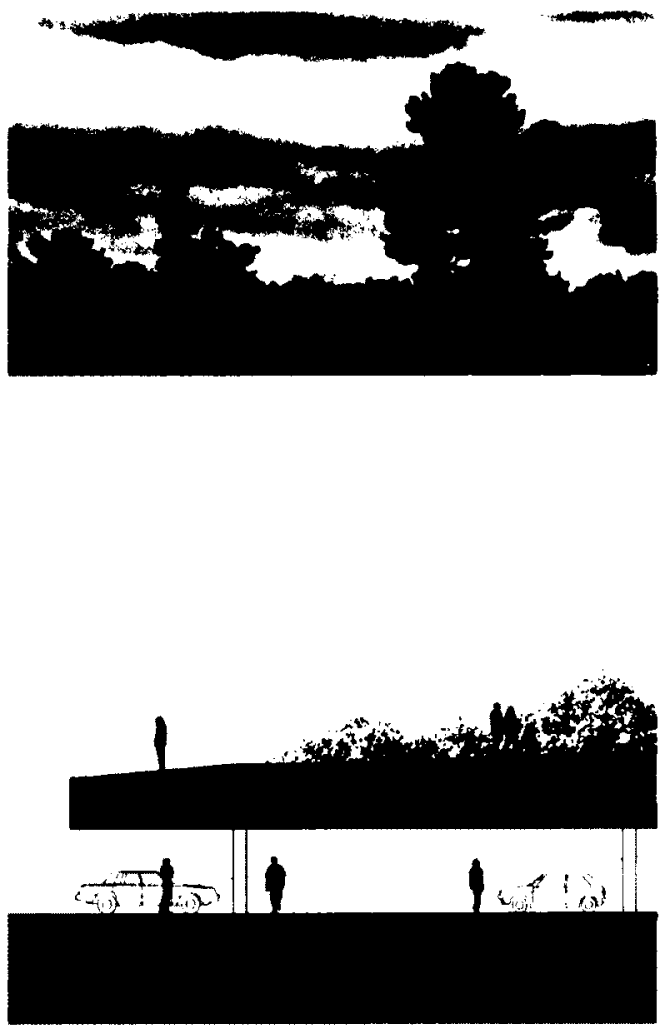

20 Natural Resources Canada, 2011 


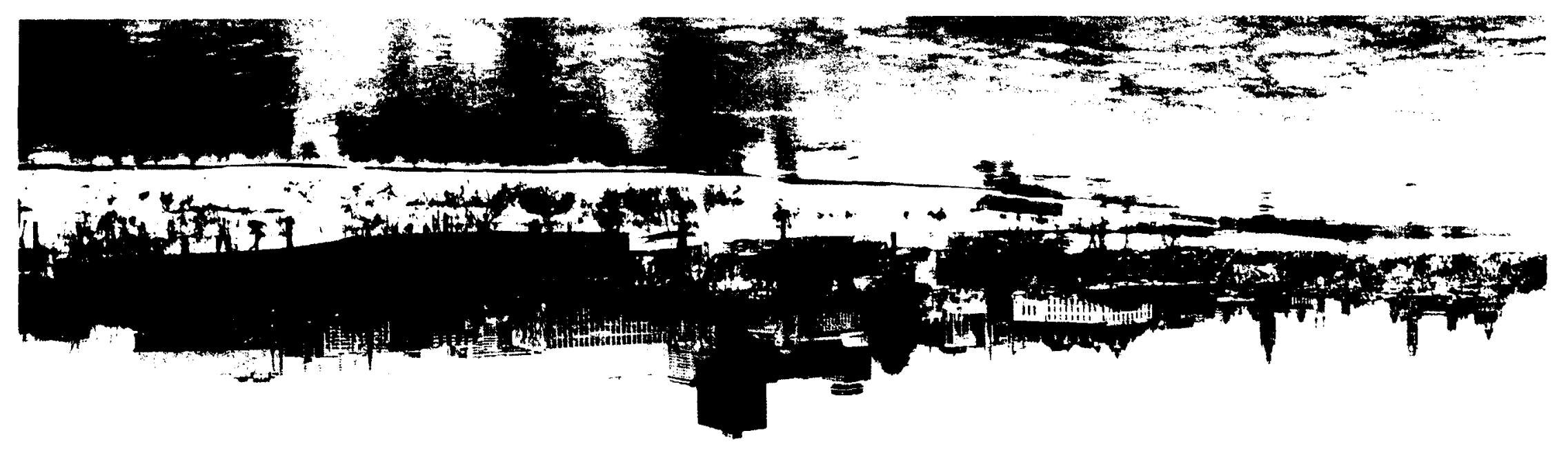




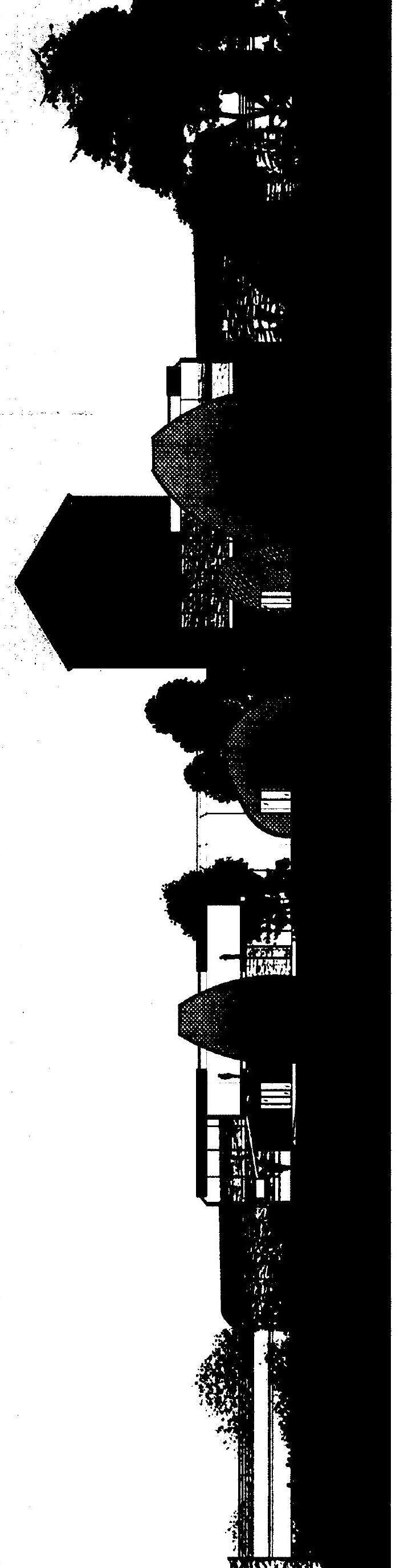




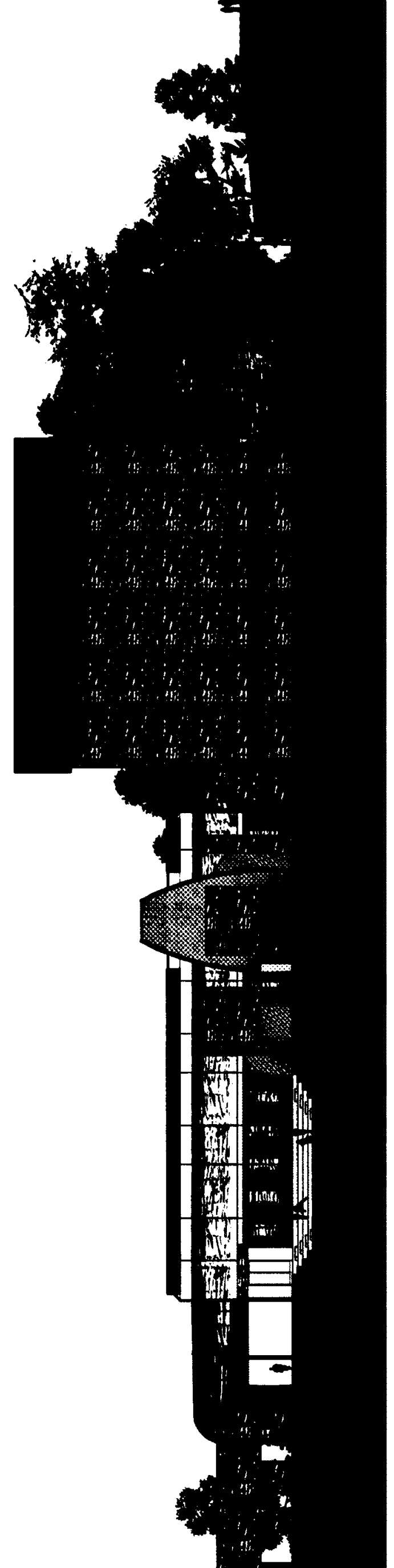



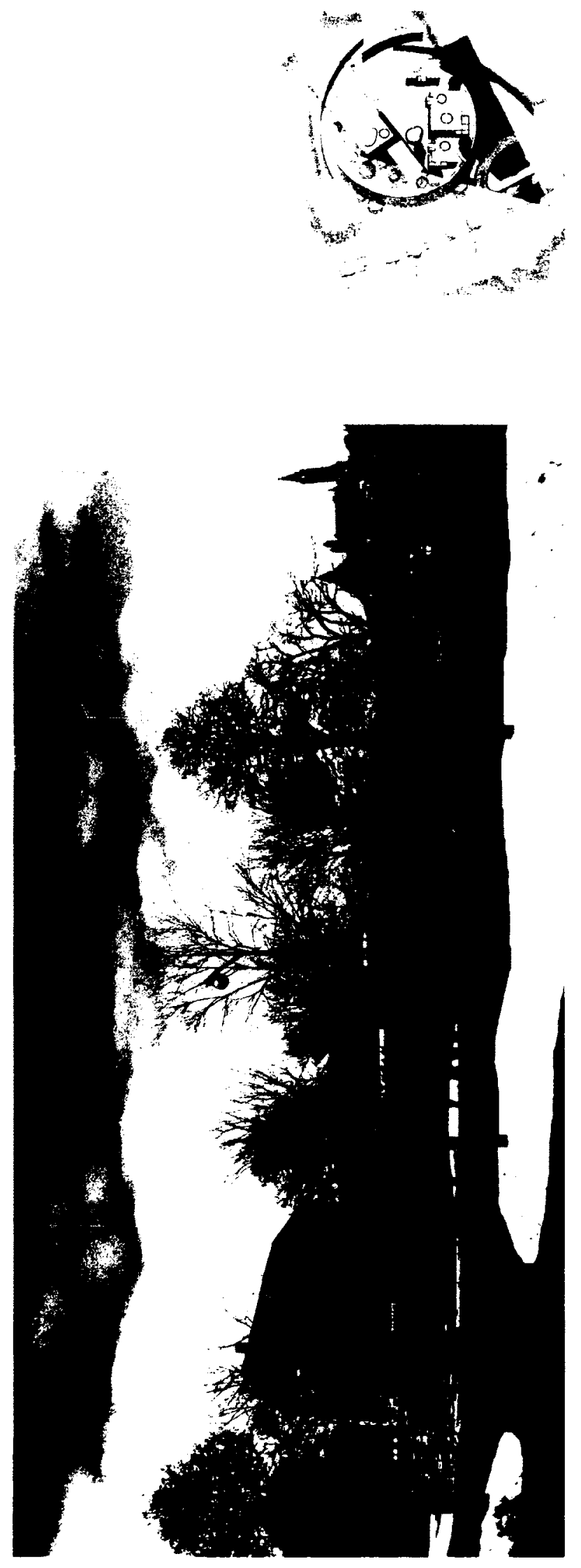

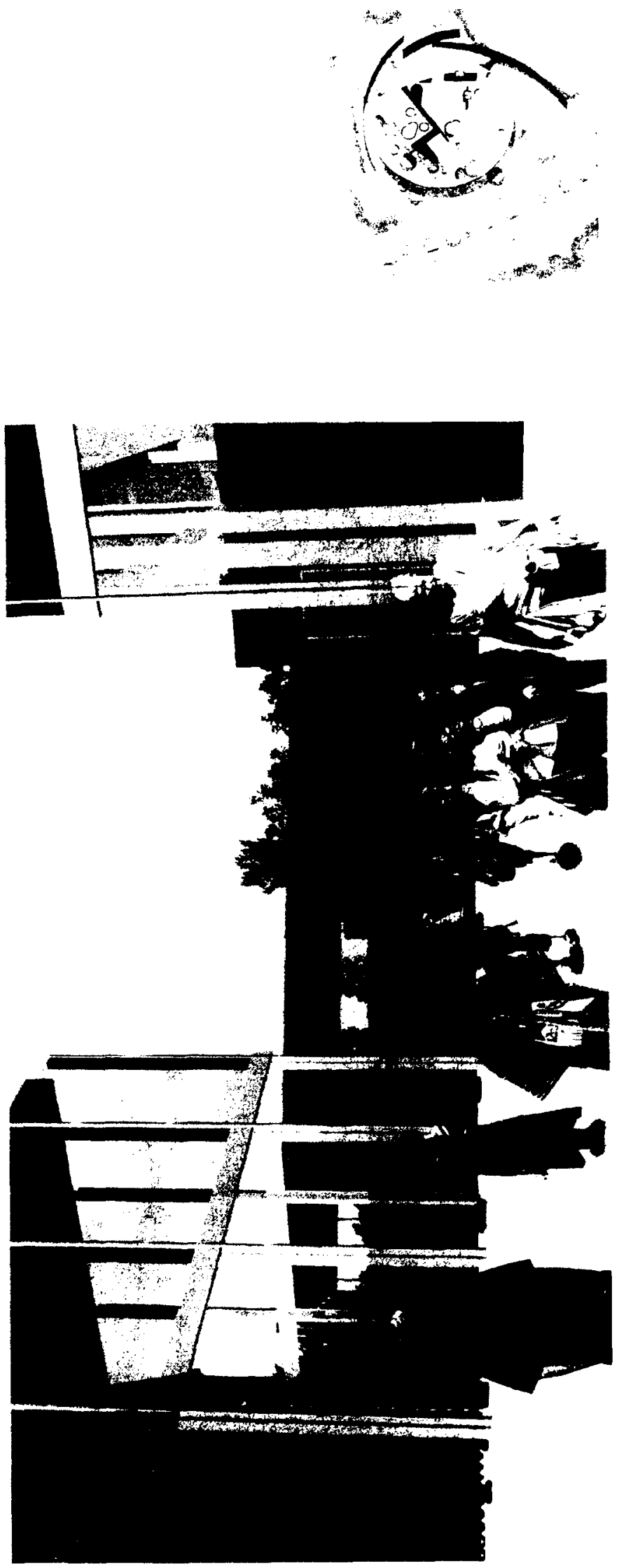

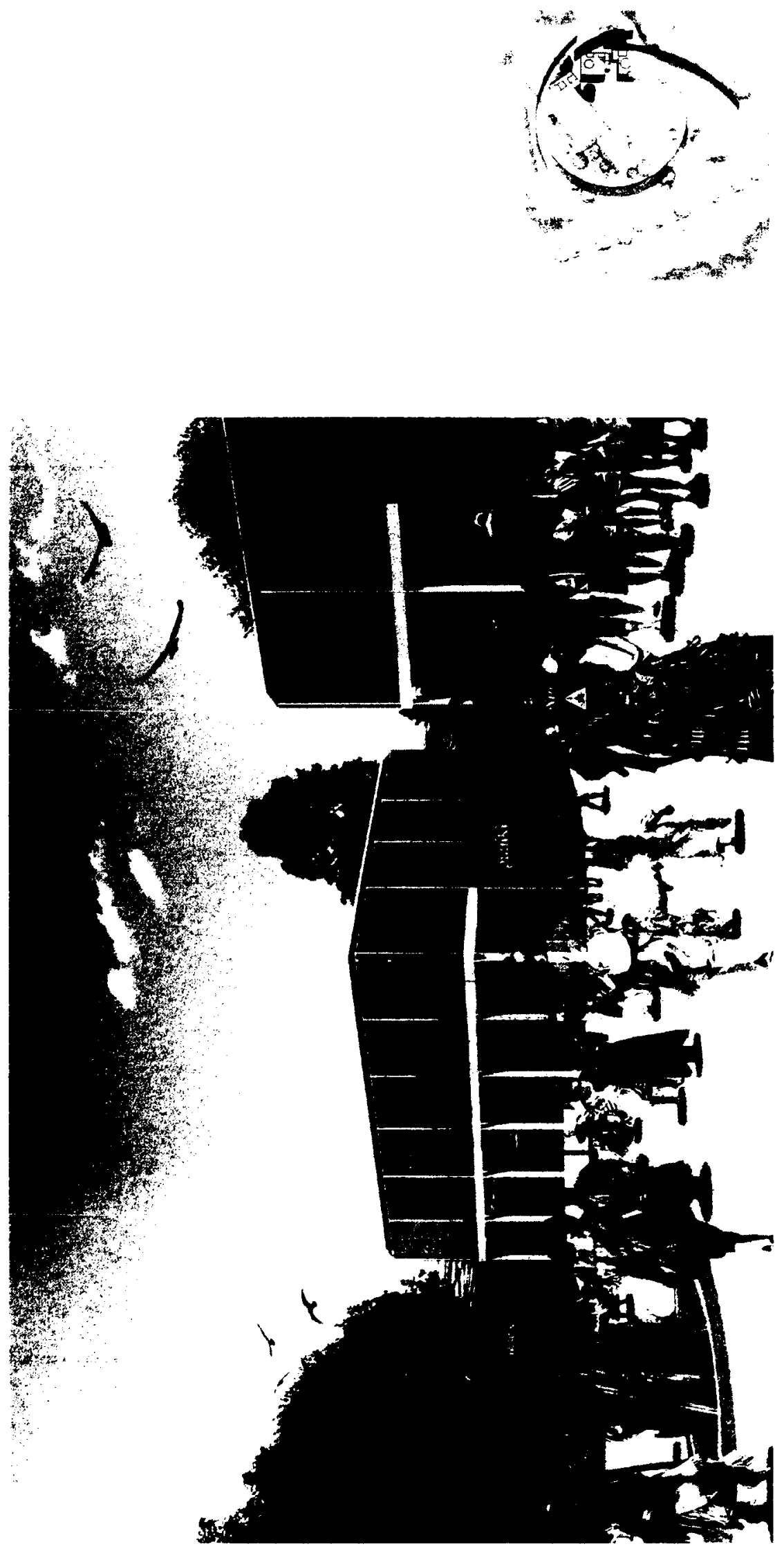


\section{Postscript}




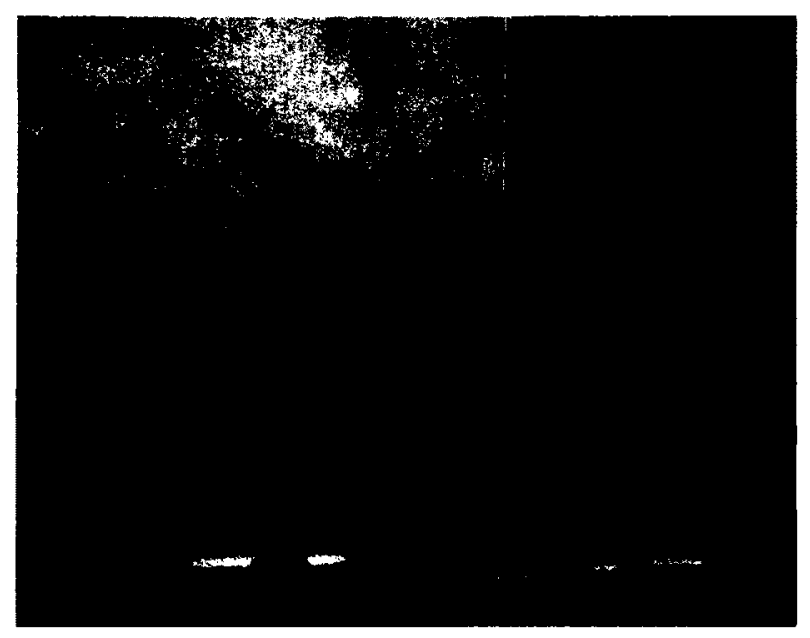

Dyck, Darryl (January 7, 2013). First Nations Idle No More protesters

hold on hand and dancing in a circle during a demonstration at

Douglas-Peace Arch 
Our Nishnaabeg Seven Fires prophecy talks about a time when it was not safe to practice our cultures, when certain families had the responsibility of hanging on, of hiding and protecting it. That time passed, an then led to a time where the next generation could pick up those beautiful things left along the path and bring life to them once again.

If we are going to make it to that Eighth fire, then we all have the responsibility for picking up those Gifts - for honouring them and making them relevant in our lives and in our nations, without rigidity and without exclusion.

Leanne Betasamosake Simpson

Indigenous researcher and activist. (in her book Lighting the Eighth Fire: The Liberation. Resurgence and Prolection of Indigenous Nations, Winnipeg: Arbeiter Ring Publishing, 2008: 209-210.) 
Several "white" architects have been "successful" (i.e. avoided an international arrogance and picturesque sentimentality ${ }^{\text {) }}$ in the design of Aboriginal cultural centres throughout the world:

Gregory Burgess choreographed the Uluru Kata-Tjuta Cultural Centre and the Brambuk Cultural Centre for the Indigenous peoples of Australia; and Renzo Piano designed the Tjibaou Cultural Centre for the Kanak Nation of New Caledonia. Both of these architects elaborated their design according to Aboriginal traditional practices through contemporary lenses. According to Jean-Marie Tjibaou, former leader of the Kanak independence and politician of New Caledonia: "The return to tradition is a myth. No people has ever achieved that. The search for identity, for a model, I

believe lies before us. [The path to take in the search for identity was one that led forward into the future, not backward into some unknowable and idealized past." 2

In this thesis, I have attempted to develop a design approach for the Indigenous Centre that is a realistic moving forward. Aboriginal ancestral culture can be a design guide, but it is unrealistic and undesirable to return to the pre-colonial era ways of life and technology. Instead, the intention has been to capitalize upon the skills and crafts of existing Algonquin people, and design at a scale and with materials that resonate with the community and allow for active participation in the construction process. The ability to build in phases has also been an important design criterion for its built-in budgetary flexibility. Finally, the core values of the community (humility, truth, courage, honesty, respect and wisdom) have provided the underlying direction of the design.

I would particularly like to thank Claudette Commanda, Band Councillor and FNCCEC

Executive Director, and Brett Cardinal, architect and principal designer at Cardinal Conley + Associates Inc. for their assistance in teasing out the needs and desires of the Algonquin people. Claudette Commanda, in her capacity as Band Councillor but also as the granddaughter of William Commanda, the initiator of this project, is the closest I could come to identifying a "client rep" for 
this project. And based on his many years working for his father, Douglas Cardinal, Brett Cardinal can be regarded as a top expert in the field of Canadian Aboriginal Architecture.

$$
\text { ...... }
$$

The Indigenous Centre aspires to address architecture as a "proactive cultural practice" 3 in order to defeat perpetuating patterns of domination. My final goal for this project is to submit a pamphlet to the Algonquin communities of the National Capital Region - Kitigan Zibi and Pikwàganagàn reserves - in which I present them with an alternative to Cardinal's proposition. By offering an alternative vision for this project, I hope to initiate discussion within the Aboriginal Nation as to what possibilities are available to them so that they can make an educated decision about the direction in which they wish to go.

The Asinabka National Indigenous Centre has the power to make the Algonquin Nation visible in a profoundly new way, a way understood in a global context and in the global language of architecture. The realization of this cultural centre could represent the initiating event that will move the Canadian Nation towards decolonization: towards the enlightenment of the Eight Fire. 


\section{Appendixes}


[T]he first prophet told of the time when the people were living as safe and secure life;

the second warned of a danger that was coming to their lands;

the third told how those who had not heeded the warning and taken precautions to move away from this danger would be destroyed;

the fourth prophecy was delivered by two prophets... a message of duality: they told of the coming of the light-skinned race. One said [the coming race] could appear as friends; the other warned that they could also be enemies under the guise of friendship. [The Anishinabe people] were warned to be on guard;

the fifth prophet warned of the false promise that could come [in[ the guise of religion;

the sixth prophet told of the pain and turmoil that would devastate the lives of the Indigenous peoples who had turned away from their old values and ways of life;

the seventh prophet talked about a time of choice making for all - for the continued exploitation of land and peoples or for a renewed respect for Mother Earth and reconciliation between Indigenous peoples and the newcomers. The double diamond at the centre of the belt reflects this hope for unity to emerge out of the duality.

THUMBADOO, Romola Vasantha. Learning from a Kindergarten Dropout: Cultural Sharings and Reflections. Ottawa: Circle of All Nations, 2005, page 51-52. 
Appendix 2:

\section{Douglas Cardinal's scheme}

"In the heart of Canada's Capital there is the "Island of Fire" (Victoria Island), sacred to all Anishinabe nations. In 1985, Grandfather Elder William Commanda had a vision to build an Asinabka National Indigenous Centre on this sacred island, as prophesized by the Seven Fires Wampum Belt which he is entrusted with. Created before contact, the prophesy calls for a time when all peoples come together in a Circle of All Nations to establish peace and harmony with each other, Mother Earth, and all relations, including all life on the planet.

Grandfather Commanda an the Algonquin Elders will be the Host Nation of this centre and trust Douglas Cardinal to bring their vision into reality. The centre is a circular building, open to the four directions and the solstice lines. It will face east as a symbol of New Dawn and Reconciliation. The building's design represents earth, air, fire, and water, and will be shaped to symbolize the seven fires of the prophesy.

The entrance in the shape of a turtle represents the Earth itself, and the spiral symbolic form will be open to all people who come to gain the Elders knowledge of true sustainability, Peace and Reconciliation, and survival and thriving of humanity for the future."

Douglas Cardinal has developed various schemes for the Asinabka National Indigenous Centre. The preservation of the industrial ruins represents a symbol of reconciliation and the intention to present the legacy of the Willson family. The first version presented a centre principally made of stone masonry, and which let the four-story section of the ruins out of the new construction. For the subsequent version, the size of the project increased so that the ruins can be incorporated inside the new construction. At this time, the building made out of stone masonry represented Elders gathered around a communal fire. The latest version (presented below) is the third schematic design. Here, curved glass panels replace the majority of the masonry. Unfortunately, the first two schemes can not be presented since they have not been published.

Douglas Cardinal Architect Inc. Asinabka National Indigenous Centre. Homepage, 2011. Accessed March 30 , 2013. <http:/Www.djcarchitect.com/02proj_cvic.html>
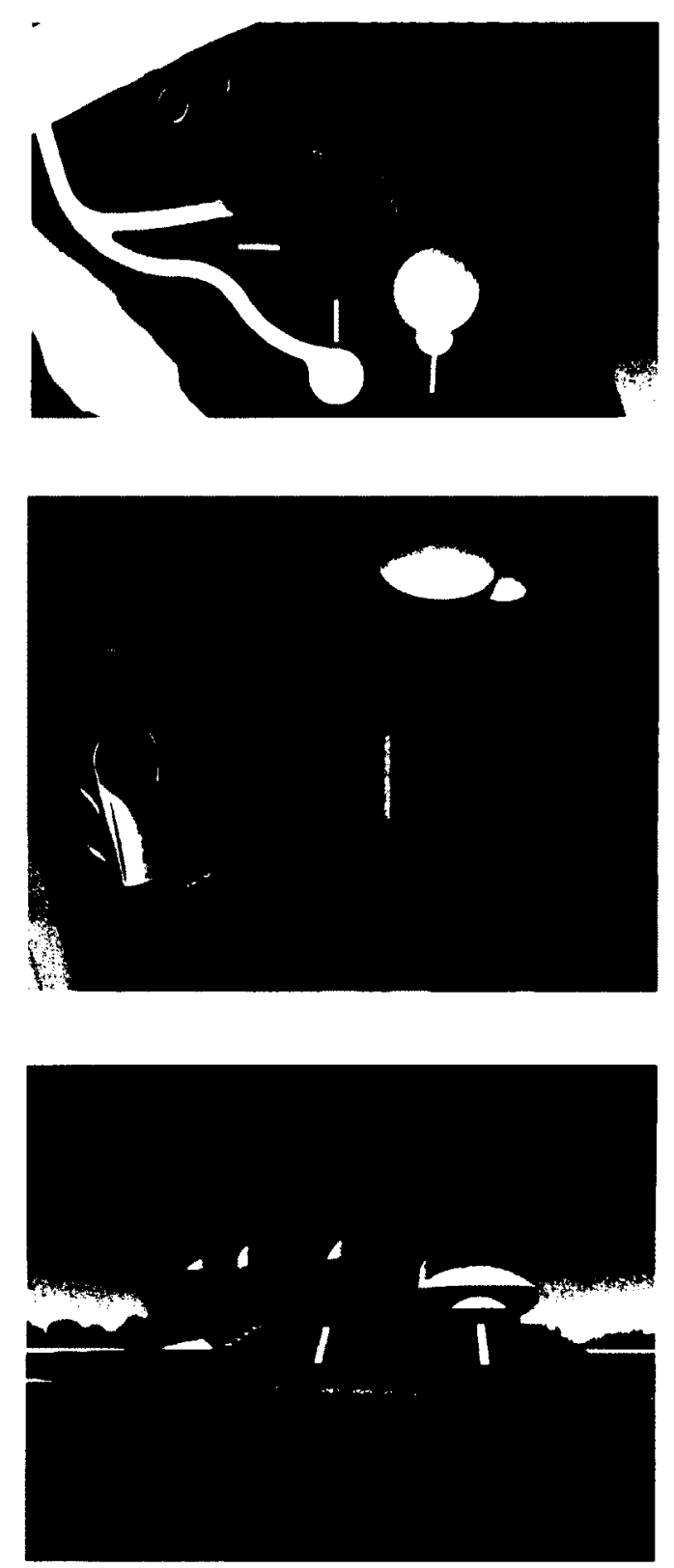


\section{Appendix 3: \\ Patterns of Domination}

After the arrival of Europeans in the Americas, the inevitable encounter between the colonists and the Native Americans created a clash of cultures, languages, and most of all, values. To achieve their aims, the European settlers exerted their power over various native nations, who were much more placatory by nature and armed only with bows and arrows. Since the first contact with the Europeans in 1603, the Aboriginals, including the Algonquin Nation, have suffered many injustices; they have seen their land invaded, their forests exploited, and their peoples' culture assimilated.

In the seventeenth century, the Algonquins inhabited the entire watershed of the Ottawa River, a territory of over $150,000 \mathrm{~km}^{2}$. Prior to the advent of Europeans, this historic river was called the "Kiji Sibi" by the Algonquins and the "Grande Rivière des Algoumequins" (Grand River of the Algonquins) by the French. ${ }^{1}$ The Algonquins controlled the Kiji Sibi, a strategic point on the trade networks that extended from the Gulf of Mexico to Hudson Bay and from the Atlantic to the Rockies. ${ }^{2}$ This strategic route was appealing for the French, led by Samuel de Champlain, seeking for a way to the northern sea, on his way to the Orient. The French needed the help of the Aboriginals (Algonquins, Montagnais, and Hurons) to guide them through this wild country. Consequently, the foreigners and the natives developed a symbiotic relationship: the French were seeking directions while the Aboriginals needed the French muskets and arquebuses to rout their enemies. $^{3}$

In addition to guiding the French through the Canadian Shield wilderness, the Jesuits required the Algonquins to convert to Christianity in order to receive support and protection from the French troops. ${ }^{4}$ This represented a conflict of fundamental philosophies and doctrines, but this was seldom understood by the Jesuits. The missionaries tried to convince the Algonquins to adopt alien ideas of heaven and hell, soul and sin, prayer and penance. ${ }^{5}$ Such words did not exist in the

Algonquin language.

Hessel, 1993: 13.

Lawrence, 2012: 19

Hessel, 1993: 42.

Idem: 57.

Idem: 61 


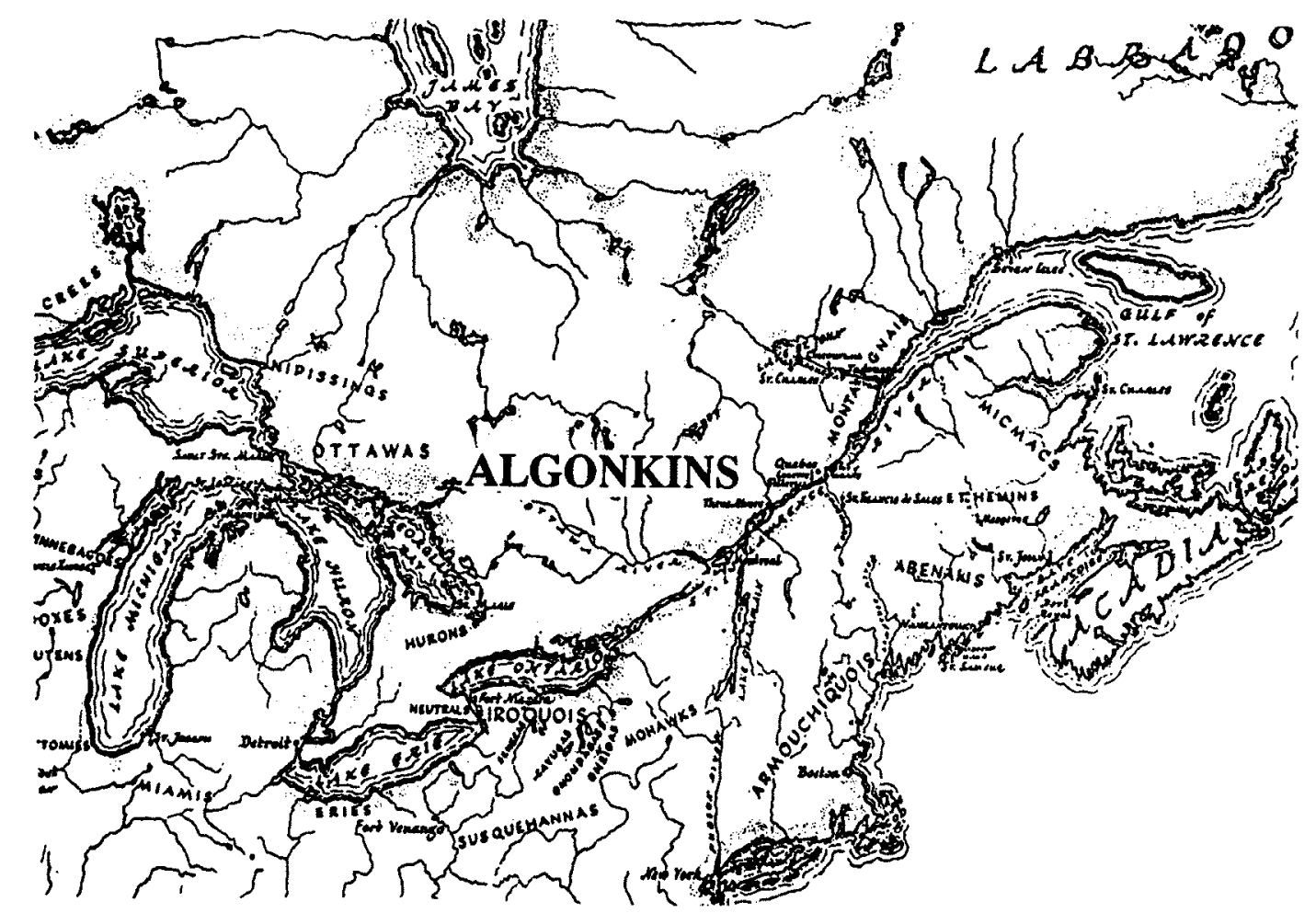

Hessel, Peter (1993). New France at the end of the seventieth century. 
On the other side, the French and the Algonquins were seen as allies; the Algonquins guided the French along the Ottawa River from the St. Lawrence River, passed the Chaudière Falls, to Morrison Island near Pembroke where their camp was established. ${ }^{6}$ The French however found on the Ottawa River an obstacle in accessing wild territories: the Algonquin chief Tessouat. Following early contacts, he saw in foreign invaders a threat to the old Indigenous culture and lifestyle. ${ }^{7}$ Therefore, soon after the death of chief Tessouat in 1636, the French made the Iroquois - the Algonquins' enemies - their allies and gave them permission to attack the Algonquins. The Algonquins had for too long kept the French from expanding up the Ottawa River. ${ }^{8}$ The French permission led to a massacre and the quasi extinction of the Algonquin Nation. Although an element of cruelty during intertribal wars prior to the arrival of the Europeans, before the introduction of firearms, the number of casualties was usually small. ${ }^{9}$ However in 1647 during the Iroquois Wars, the fierce determination, combined with modern weapons, resulted in disaster. The Algonquins who survived the massacre and sought refuge in the French missions were almost totally extinguished by transmittable diseases and alcohol-related problems. ${ }^{10}$ By design and by circumstances, their traditional values, lifestyles, religion, mythology, culture, and self-respect were destroyed. ${ }^{11}$ The Algonquin Nation would have disappeared completely, had it not been for the establishment of two reservations in the nineteenth century at Golden Lake in Ontario -

Pikwàkanagàn - and at River Desert in Québec - Kitigan Zibi. ${ }^{12}$

Before the establishment of these reservations, the Algonquin Nation received no recognition from foreigners and other native nations. In the 1680's, the Ottawa Nation - originally from Manitoulin Island located on Lake Huron - controlled the fur trade on the Ottawa River, since the Algonquins were forced to vacate their homelands after the Iroquois Wars. ${ }^{13}$ During those

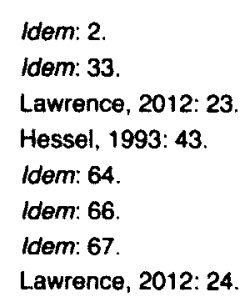


years, some French began referring to the "Grande Rivière des Algoumequins" as the "Rivière des Outaouais" (River of the Ottawas). Although the Ottawas never lived anywhere near the Ottawa River and the Ottawa Valley, that name remained while the original name was forgotten. ${ }^{14}$

The nonrecognition of the Algonquins as natives of the Kiji Sibi Valley continued after the British conquest of New-France in 1759. Prior to the Constitutional Act of 1791, the Royal Proclamation of 1763 signed by King George III solemnly stated that "the Aboriginals shall be maintained in the lands they inhabit if they choose to remain there". 15 However, white settlement following the American Revolution and the War of 1812 - as former Wrightstown (Hull) and former Bytown (Ottawa) - resulted in treaties and surrenders of virtually all Indigenous land in the territories of the Upper and Lower Canada. ${ }^{16}$ This was, of course, contrary to the expressed promises of the British Crown. The major portion of Algonquin territory south of the Ottawa River (i.e. Upper Canada) was surrendered by the Mississauga Nation originally from Georgian Bay. A treaty was signed between the Mississaugas and the British ceding $8,000 \mathrm{~km}^{2}$ of Algonquin land illegally to the Crown. ${ }^{17}$ In a vain effort the Algonquins submitted numerous claims, demands and petitions to save their land from the indiscriminate and injudicious destruction by settlers - the production of squared and sawn lumber along with the development of industries depleted the white pine forests and the Ottawa River. ${ }^{18}$ Their pleas and requests were ignored; the land was irretrievably lost to settlers and lumbermen. Thus, the Aboriginals became squatters of the land they have lived in for thousands of years. ${ }^{19}$ Nevertheless, the Algonquins never surrendered the Ottawa Valley.

For the Algonquins, partial adaptation to white society - through jobs, schooling, and most of all, through church attendance - was fundamental to survival. Following the nineteenth century, people of foreign origin were greater in number than the natives. ${ }^{20}$ Consequently, the

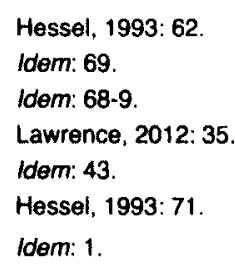


Algonquins needed to participate in this new type of society in order to receive remuneration, since the establishment of settlements had reduced their territory therefore their possibilities of hunting and trapping. Algonquins have worked for lumber company, such as the Canadian International Paper Company (CIP) as log drivers. They have worked also as guides for bear and moose hunting, and as craftsman. ${ }^{21}$ Thus the Algonquins gradually lost their language and the stories and songs that went with it; this adaptation, over time, caused the deterioration of the traditional Indigenous culture. 22

With the recent Algonquin land claim, the Algonquin Nation will have the power to reaffirm their legitimate presence in the National Capital Region and the recognition of the Ottawa Valley as their homeland. The land claim has been put forward only by the Algonquins of Ontario since the Algonquins of Québec have evolved into another government. The Constitutional Act of 1791 divided the homeland of the Algonquins between the Upper and Lower Canada - now the provinces of Québec and Ontario - with the Ottawa River as boundary line. ${ }^{23}$ Thus the Algonquin homeland was fractured ever after. This boundary line was more than only physical; this line represented the division between two languages, French and English, which increased the fragmentation of the Algonquin Nation. At last, the presence of the Algonquins on Victoria Island would force formal recognition from both the Canadian federal and the Ontario provincial governments, thus representing a critical step in the reconstitution and rediscovery of the Algonquin Nation culture while simultaneously solidifying their cultural identity and creating a platform for the ongoing participation and growth within Canadian society.

21 Idem: 94 .

22 Lawrence, 2012: 52

23 Idem: 34 


\section{Carleton}

Canade's Capital Univeralty

\section{Cretecon Univerdity Remerch Office}

Research Ethics Ecoard

i325 Dumton Tower

atawa, ON K1S 5Bs Canada

incesocadetences

\section{Ethica Clanance Form}

This is to certify that the Carteton University Research Ethics Board has examined the application for ethical dearance. The REB found the research project to meet appropriate ethical standards as outlined in the Tri-Council policy Stacement: Echical Conduct for Research Involving Humans, $2^{\text {me }}$ edition and, the carteton University Pollicles and Procedures for the Ethical Conduad of Research.

\section{o Renewed of ortingl deranom \\ Original date of clearanca: \\ Date of claranca 26 April 2013 \\ Recearchers Sophis Lemothe, M. Arch. student \\ Depertment School of Archiliecture and Urbaniem \\ Supervieor Prof. Lucle Fontain, School of Archittecture and Urbantem \\ Project number 13-1272 \\ Tith of project Uighting the Elght Fro: Acknowledgement, Accountebillity and \\ Gonting the Eight Fira: Aclo}

Clearance expires: 31 May 2014

All remearchers ere gowemed by the following conditions:

Annual Status Report: You are required to submit an Annual Status Report to either renew clearance or close the file. Fallure to submit the Annual Status Report will result in the immedlate suspension of the project. Funded projects will have accounts suspended until the report is submitted and approved.

Chenges to the project: Any changes to the project must be submitted to the Carleton University Research Ethics Board for approval. All changes must be approved prior to the continuance of the research.

Adveren wantw: Should any participant suffer adversely from their partidpation in the project you are required to report the matter to the Carleton University Research Ethics Board. You must submit a written the cituation.

Suapanaton or tormination of clearanca: Failure to conduct the research in accordance with the

princaples of the $7 H$-Councll Pollcy Statement: Ethical Conduct for Research Involving Humans, $2^{\text {nd }}$ edittion suspension or terminarion of the research prodect. 


\section{References}


ADAM, Mohammed. "Land deal faces court challenge". In The Ottawa Citizen, December 20, 2012. Accessed March 12, 2013. <http:/t www.ottawacitizen.com/Land+deal+faces+court+challenge/7729225/ story.html>

Algonquins of Pikwwàkanagàn. "Culture". Homepage, 2012. Accessed February 18, 2013. <http://algonquinsofpikwakanagan.com/culture.php>

Associated Press. "American Indian activist Means dies". In Times Union, October 22, 2012. Accessed February 20, 2013. <http:// www.timesunion.com/entertainment/article/American-indian-activistMeans-dies-3972622.php>

BOSWELL, Randy. "Sadness in the celebration". In The Ottawa Citizen, December 5, 2012. Accessed March 12, 213. <http:// www.ottawacitizen.com/life/Sadness+celebration/7750688/story.htmb

BOUCHER, Louis Nathalie. Interculturalité et esprit du lieu: Les paysages artialisés des Chutes des Chaudières. Ottawa: Département de géographie de l'Université d'Ottawa, 2012, 330 pages.

BROWNELL, Vivian and CATLING, Paul. "The Flora and Ecology of Southern Ontario Granite Barrens". In Savannas, Barrens, and Rock Outcrop Plant Communities of Nonth America, edited by Anderson, Fralish and Baskin, Cambridge: Cambridge University Press, 1999, 480 pages.

BRUCHAC, Joseph. "The Circle of Stories". In Buried Roots and Indestructible Seeds, by K. Blaeser, M. Linquist and M. Zanger. Madison: University of Wisconsin Press, 1995, pages 9-20.

BURGESS, Gregory. Towards an Ecology of Culture. In $A+U$ : Architecture and Urbanism, Tokyo, Volume 320, May 1997, pages 102-111.

Bytown Museum. Ottawa History: Fifteen Years at a Time. Homepage, 2012. Accessed December 02, 2012. <http://www.bytownmuseum.com/en/ ottawahistory.html>

Canadian Museum of Civilization Corporation. The Chaudière Dam. Homepage, June 29, 2010. Accessed December 2, 2012. <http://www.civilization.ca/ cmc/exhibitions/hist/hull/rw_28_ie.shtmls

Canadian Press. "News images and photo licensing". Homepage, 2013. Accessed April 4, 2013. <http://www.thecanadianpress.com/ pholography. aspx?id=157>
CARDINAL, Bret. "Healing Architecture". In TEDx Ottawa, November 11, 2011. Accessed January 18, 2013. <http://www. youtube.com/watch?v= YWwiXEqckx8>

CBC Ottawa. "Asinabka Indigenous Film and Media Arts Festival". In CBC News, June 16, 2012. Accessed March 12, 2013. <http://www.cbc.ca/ intownandout/2012/06/16/asinabka-indigenous-film-and-media-artsfestival/s

CBC News Canada. "Canada ranked low in UN native report". In CBC News, April 11, 2005. Accessed February 20, 2013. <http://www.cbc.ca/news/ canada/story/2005/04/11/UNNatives-050411.html>

CBC News Canada. "Quebec Algonquins question Ontario land claim". In CBC News, February 5, 2013. Accessed March 12, 2013. <http://www.cbc.ca/ news/canada/ottawa/story/2013/02/05/ottawa-algonquin-land-claimquebec-reserves.html>

CIBBON, Jennifer. "Keeper of the wampum: William Commanda, Algonquin elder". In CBC News, August 3, 2011. Accessed January 18, 2013. <http://www.cbc.ca/news/canada/story/2011/08/03/f-william-commandaalgonquin-elder.html>

Cintec Worldwide. "Cintec Anchoring System". Homepage, 2010. Accessed

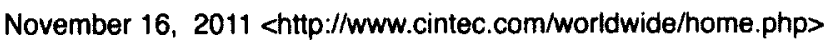

Circle of All Nations. "Final Report: Algonquin Elders' Gathering to Develop a Vision for Victoria Island". Homepage, March 28, 2002. Accessed November 14, 2012. <http://www.angelfire.com/ns/circleofallnations/ H2.htmls

Circle of All Nations. "Project to Redevelop the Hydro electric Potential of the Existing Chaudière Island Site in Ottawa". Homepage, December 11 2006. Accessed November 14, 2012. <http://www.google.com/url? $\mathrm{sa}=1 \& \mathrm{rct}=\mathrm{j} \& \mathrm{q}=\& \mathrm{esrc}=\mathrm{s} \&$ source $=$ web\& $\mathrm{cd}=1 \& \mathrm{v}$ ed $=0 \mathrm{CDCQFjAA \& url}=\mathrm{htt}$ $\% 3 \mathrm{~A} \% 2 \mathrm{~F} \% 2 \mathrm{Fw} w$.angelfire.com\%2Fns\%2Fcircleofallnations \%2FGWC2.pdf\&ei=073pUMPiAbKQ0QGm84DYCw\&usg=AFQjCNFkhjZ RQ_ais5XLwQN2wXuqcs/4Dg\&bvm=bv.1355534169,d.dmQ>

Circle of All Nations. "The Sacred Wampum Belts". Homepage, 2008. Accessed February 20, 2013. <http://www.circleofallnations.ca/s 
Citizen. "Indians won't quit Embassy"'. In The Ottawa Citizen, February 5, 1975, page 14

City of Ottawa. "A Report on the Vision for the Asinabka National Indigenous Centre". Homepage, February 14, 2010. <http://ottawa.ca/calendar/ ottawa/citycouncil/occ/2010/11-19/cpsc/02-\%20report\%20on\%20the \%20vision\%20for\%20the\%20Askiabka.htm>

DICKSON-GILMORE, Jane and LA PRAIRIE, Carol. Will the Circle be Unbroken?: Aboriginal Communities, Restorative Justice, and the Challenges of Conflict and Change, Toronto: University of Toronto Press 2007,268 pages.

Douglas Cardinal Architect Inc. "Asinabka National Indigenous Centre". Homepage, 2011. Accessed March 20, 2013. <http:// www.djcarchitect.com/02proj_cvic.html

DOVEY, Kim. Framing Places: Mediating power in built form. London; NewYork: Routledge, 2008, $2^{\text {nd }}$ ed., 242 pages.

EGLASH, Ron. "Anishinaabe Arcs". Culturally Situated Design Tools, 2003. Accessed November 14, 2012. <http://csdt.rpi.edu/na/arcs/ background $4 . \mathrm{html}>$

Encyclopaedia Britannica. Algonquin: Village of Pomeiock. Homepage, 2013. Accessed January 2, 2013. <http://www.britannica.com/EBchecked/ media/106339/Sketch-of-the-Algonquin-village-of-Pomeiock-nearpresent-days

FINDLEY, Lisa. Building Change: Architecture, Politics and Cultural Agency. London and New York: Routledge, 224 pages.

First Nations Confederacy of Cultural Education Centres. "About us". Homepage, 2010. Accessed March 12, 2013. <http://www.fnccec.com/en/about

GABRIEL, Ellen. "Sovereignty and Resistance". In Aboriginal Perspectives, 2009. Accessed March 12, 2013. <http:/www3.nfb.ca/enclasse/doclens/visau/ index.php? mode $=$ theme\&language $=$ english $\&$ theme $=30665 \&$ film $=16933 \&$ excerpt $=612110 \&$ submode $=$ about\&expmode $=1>$

Gerrard, Hossak and associates inc. Salvage archeology: Carbide Mill Victoria Island. Ottawa: National Capital Commission, August 1983, 28 pages.

GRAY, Lynda. First Nations 101. Vancouver: Adaawx Publishing, 2012.
HESSEL, Peter. The Algonquin Nation. Arnprior, Ontario: Kichesippi Books 1993, 124 pages.

Idle No More. Homepage, 2013. Accessed March 12, 2013. <http:// idlenomore.ca/s

IPAC and MASS LBP. "150! Canada". Homepage, 2010. Accessed February 20, 2013. <http://www.masslbp.com/150canada_new/index.htm>

JACCOUD, Mylène. "Les cercle de guérison et les cercles de sentence autochtones au Canada". In Criminologie, Montréal, Volume 32, Spring 1999, pages $7-105$

Justice Education Society of BC. "Aboriginal Restorative Justice Remedies". Homepage, 2012. Accessed October 14, 2012. <http:/l www.justiceeducation.ca/research/aboriginal-sentencing/restorativejustice>

KEDDY, Catty J. Forest History of Eastern Ontario. Kemptville: Eastern Ontario Model Forest Group, 1998, 45 pages.

LAWRENCE, Bonita. Fractured Homeland: Federal Recognition and Algonquin Identity in Ontario. Toronto; Vancouver: UBC Press, 2012, 327 pages.

LAWRENCE, Bonita and ENAKSHI, Dua. "Decolonizing Antiracism". Social Justice, Volume 32, Issue 4, 2005, pages 120-143. December 2, 2012. <http://Www.anti-racism.ca/content/\%E2\%80\%9Cdecolonizing-antiracism $\%$ E2\%80\%9D-bonita-lawrence-and-enakshi-dua>

MAJAURY, Heather. "Living Inside Layers of Colonial Division: A Part of Algonquin Story", in Atlantis, Volume 29.2, Spring 2005.

Merriam-Webster. Dictionary. Homepage, 2013. Accessed, January 2, 2013. <http://www.merriam-webster.com>

MOORE, Elwin. "The 'Embassy': An old mill becomes a symbol of Indian pride". In The Ottawa Citizen, October 2, 1974, pages 1-2.

NANJI, G.A. "Fire destroys native people's island embassy". In Journal, March 21,1975 , page 7 .

National Capital Commission. "Confederation Boulevard". Capitale, 2012. Accessed December 7, 2012. <http://www.canadascapital.gc.ca/placesto-visit/confederation-boulevard> 
Natural Resources Canada. "Eastern white pine". Homepage, November 18, 2011. Accessed March 12, 2013. <https:/tidct.nrcan.gc.ca/trees/ factsheet/50>

NEIHARDT, John G. Black Elk Speaks: Being the Life Story of a Holy Man of Oglala Sioux. Lincoln: University of Nebraska Press, 1932, 270 pages.

Omàmiwinini Pimadjwowin. "Traditional Algonquin Teaching". Homepage, 2010. Accessed December 2, 2012. <http:/www.thealgonquinway.ca/English/ learning-resource-e.php?lesson $=4>$

Ontario Ministry of Aboriginal Affairs. "Algonquin Land Claim". Homepage, March 2013. Accessed March 20, 2013. <http://www.aboriginalaffairs.gov.on.ca/ english/negotiate/algonquin/algonquin.asp>

Ottawa River Institute. "Our Watershed". Homepage, 2013. Accessed March 12, 2013. <http://www.ottawariverinstitute.ca/resources/our-watershed>

Oujé-Bougoumou Cree Reserve. "History". Homepage, 2000. Accessed February 25, 2013. <http://www.ouje.ca/content/our-story/history.php>

Parks Canada. Canada's Historic Places. Homepage, 2002. Accessed, November 22, 2012. <http:/www.historicplaces.ca/en/homeaccueil.asp $x>$

PITAWANAKWAT, Brock. " Bimaadziwin Odenaang: A Pathway to Urban Nishinaabe Resurgence". In Lighting the Eight Fire: the liberation, resurgence and protection of Indigenous nations, Ed. Leanne Simpson, Winnipeg: Arbeiter Ring Publishing, 2008, pages 161-173.

PRITCHARD, Trevor. "Domtar sells Ottawa River hydro assets, still no buyer for Chaudière Island land". Open File, June 13, 2012. Acessed December 7, 2012. <http:/Www.openfile.ca/ottawa/blog/2012/domtar-sells-ottawa-riverhydro-assets-still-no-buyer-chaudi\%C3\%ABre-island-lands

Public Safety Canada. "The Four Circles of Hollow Water". Homepage, September 14, 2010. Accessed November 12, 2012. <http:/l www.publicsafety.gc.ca/res/cor/apc/apc-15-eng.aspx>

SHERMAN, Paula. "The Firendship Wampum: Maintaining Traditional Practices in Our Contemporary Interactions in the Valley of the Kiji Sibi". In Lighting the Eight Fire: the liberation, resurgence and protection of Indigenous nations, Ed. Leanne Simpson, Winnipeg: Arbeiter Ring Publishing, 2008, pages $111-125$
SIMPSON, Leanne. "Oshkimaadiziig, the New People". In Lighting the Eight Fire: the liberation, resurgence and protection of Indigenous nations, Ed. Leanne Simpson, Winnipeg: Arbeiter Ring Publishing, 2008, pages 13-21.

SIMPSON, Leanne. "Our Elder Brothers: The Lifeblood of Resurgence". In Lighting the Eight Fire: the liberation, resurgence and protection of Indigenous nations, Ed. Leanne Simpson, Winnipeg: Arbeiter Ring Publishing, 2008, pages 73-87.

SMITH, Teresa. "Algonquin communities at odds over competing claims to Ottawa River lands". In The Ottawa Citizen, January 24, 2013. Accessed March 12, 2013. <http://www.ottawacitizen.com/technology/Algonquin +communities+odds+over+competing+claims+Ottawa+River+lands/ 7863103/story.html>

SNYDER, Jon R. Introduction to The End of Modernity: Nihilism and Hermeneutics in Postmodern Culture, by Gianni Vattimo. Baltimore: The Johns Hopkins University Press, 1988, pages vi-Iviii.

de SOLÀ-MORALES, Ignasi. "Differences: Topographies of Contemporary Architecture". Massachusetts: MIT Press, 1997, 154 pages.

STEVENSON, Jean. "The Circle of Healing". In Native Social Work Journal, xxx, Sudbury, Volume 2 (1), April 1999, pages 8-21.

TALAGA, Tanya. "Historic Algonquin claim of Ottawa area nearly done". In Toronto Star. June 1, 2012. Accessed September 17, 2012. <http:// www.thestar.com/news/ontario/article/1204431--historic-algonquin-claimof-ottawa-area-nearly-done>

TAMMEMAGI, Hans. "Canada's Only Urban Native Attraction Has a Vision". In Indian Country, November 20, 2012. Accessed March 12, 2013. <http:// indiancountrytodaymedianetwork.com/article/canada $\% 25 \mathrm{e} 2 \% 2580 \%$ 2599s-only-urban-native-attraction-has-a-vision-145765>

THUMBADOO, Romola Vasantha. Learning from a Kindergarten Dropout: Cultural Sharing and Reflections. Ottawa: Circle of All Nations, 2005, 188 pages.

Truth and Reconciliation Commission of Canada. "Our Mandate". Homepage, 2013. Accessed February 25, 2013. <http://www.trc.ca/websites/ trcinstitution/index.php?p=7> 
Université Laval and University of Toronto. "Trudeau, Pierre Elliott". Dictionary of

Canadian Biography Online, 2000. Accesses December 6, 2012. <http $/ l$ www.biographi.ca/009004-119.01-e.php?id_nbr=8418>

Vancouver Coastal Health. Aboriginal Health. Homepage, 2012. Accessed November 22, 2012. <http://aboriginalhealth.vch.ca/terms.htm>

VATTIMO, Gianni. The End of Modernity: Nihilism and Hermeneutics in Postmodern Culture. Baltimore: The Johns Hopkins University Press, 1988,190 pages.

WALKER, J.R. The Sun Dance and Other Ceremonies for the Oglala Division of the Teton Dakota. Hong Kong: Forgotten Books, 270 pages. 